\title{
DESENVOLVIMENTO DE UM SISTEMA DE APLICAÇÃO LOCALIZADA DE CALCÁRIO A TAXAS VARIÁVEIS
}

\author{
Domingos Guilherme Pellegrino Cerri
}

Dissertação apresentada à Escola Superior de Agricultura "Luiz de Queiroz", Universidade de São

Paulo, para obtenção do título de Mestre em Agronomia, Área de Concentração: Máquinas Agrícolas.

P I R A C I C A B A

Estado de São Paulo - Brasil

Dezembro - 2001 


\title{
DESENVOLVIMENTO DE UM SISTEMA DE APLICAÇÃO LOCALIZADA DE CALCÁRIO A TAXAS VARIÁVEIS
}

\author{
Domingos Guilherme Pellegrino Cerri \\ Engenheiro Agrônomo
}

Orientador: Prof. Dr. Luiz Antonio Balastreire

\begin{abstract}
Dissertação apresentada à Escola Superior de Agricultura "Luiz de Queiroz", Universidade de São Paulo, para obtenção do título de Mestre em Agronomia, Área de Concentração: Máquinas Agrícolas.
\end{abstract}

P I R A C I C A B A

Estado de São Paulo - Brasil

Dezembro - 2001 
Dados Internacionais de Catalogação na Publicação (CIP)

DIVISÃO DE BIBLIOTECA E DOCUMENTAÇÃO - ESALQ/USP

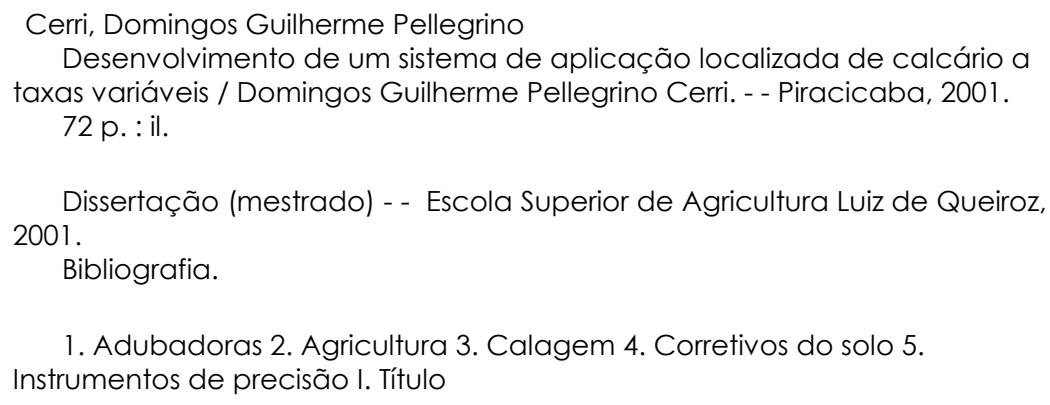

CDD 631.8

\section{"Permitida a cópia total ou parcial deste documento, desde que citada a fonte - $\mathrm{O}$ autor"}


Aos meus pais Ana e Carlos, avó Biloca e irmão Ado,

pela minha formação acadêmica e pessoal

dedico

À minha esposa Tatiana,

com muito amor

ofereço 


\section{AGRADECIMENTOS}

A elaboração de um trabalho científico, normalmente envolve a orientação, a colaboração e o incentivo de várias pessoas. De maneira simples, mas, sincera, quero registrar meus agradecimentos e gratidão às seguintes pessoas e entidades, das quais, a experiência científica, os serviços técnicos e o apoio financeiro nos permitiram desenvolver este trabalho dentro de um clima seguro e tranqüilo:

A Deus, por todas as coisas que a vida nos mostra para podermos crescer como pessoa.

Ao Prof. Dr. Luiz Antonio Balastreire, pela orientação geral e amizade demonstrada em todas as fases desta dissertação.

Aos professores Dr. Tomaz Caetano Ripoli e Dr. Walter Francisco Molina Junior, da ESALQ/USP e ao Dr. Ulisses Rocha Antuniassi, da Faculdade de Ciências Agronômicas - UNESP responsáveis pelas sugestões e orientação na correção desta dissertação.

Ao Departamento de Engenharia Rural da ESALQ/USP pela oportunidade concedida.

À Fundação de Amparo à Pesquisa do Estado de São Paulo, que nos proporcionou, com presteza e seriedade, os meios financeiros para execução do presente trabalho.

A todos os professores e funcionários do Departamento de Engenharia Rural, pelos ensinamentos e cordialidade. 
Ao Eng. Juarez Reno Amaral e Técnico Áureo Oliveira pela colaboração no desenvolvimento dos sistemas eletrônicos.

Aos professores Dr. Eder Cassola Molina e Nelsi Cogo de Sá do Instituto Astronômico e Geofísico da Universidade de São Paulo por fornecer o algoritmo de transformação de coordenadas geográficas em Universal Transverse Mercator (UTM).

Aos amigos Fabio Baio, Julio Esquerdo, Juliano Leal pelo auxílio nos ensaios de campo.

Aos colegas da Pós-graduação, pela amizade e colaboração.

A todos aqueles que, de alguma forma, contribuíram para a realização deste trabalho, muito obrigado. 


\section{SUMÁRIO}

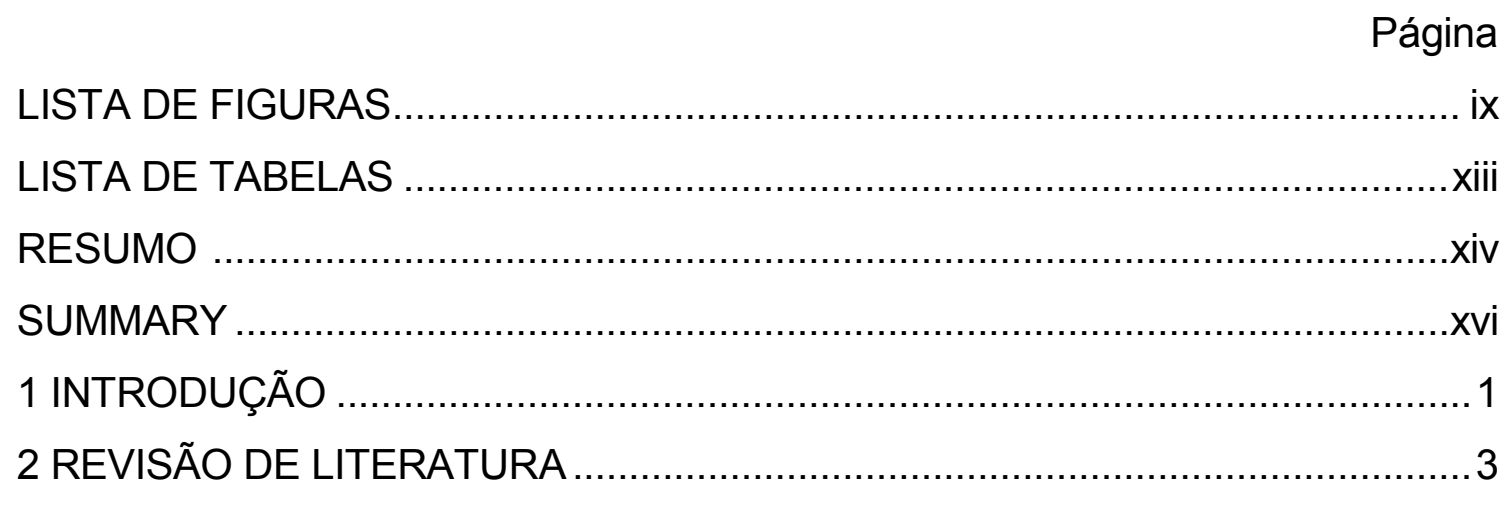

2.1 Variabilidade espacial do solo .......................................................... 3

2.2 Gerenciamento localizado de culturas e conceito da aplicação

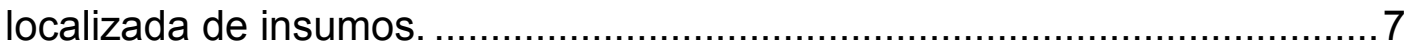

2.3 Exemplos de utilização da técnica de aplicação localizada de insumos ...... 10

2.4 Distribuidora de fertilizantes e corretivos.......................................... 12

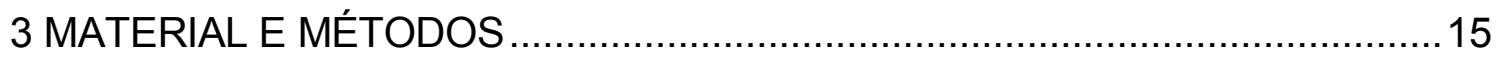

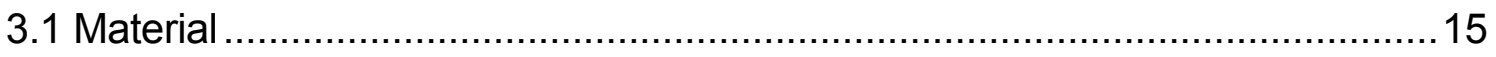

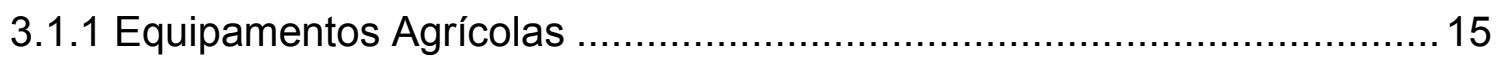

3.1.2 Sistema de Posicionamento ....................................................... 16

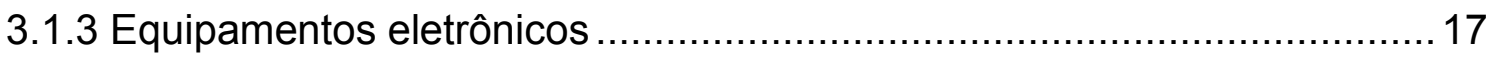

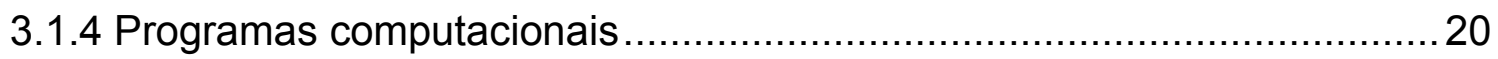

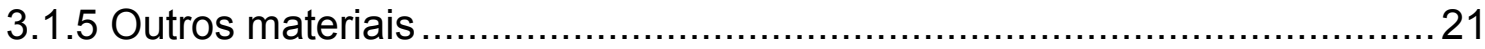

3.1.6 Sistema de controle automático montado na distribuidora de calcário ....21

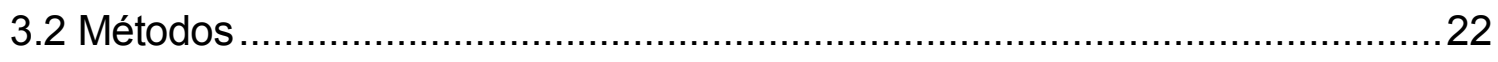

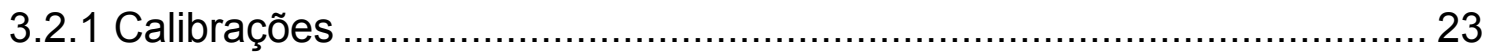

3.2.1.1 Calibração do radar......................................................... 23 
3.2.1.2 Calibração da vazão da distribuidora de calcário............................... 24

3.2.1.3 Calibração do sensor potenciométrico ............................................. 25

3.2.1.4 Calibração do mecanismo dosador da distribuidora

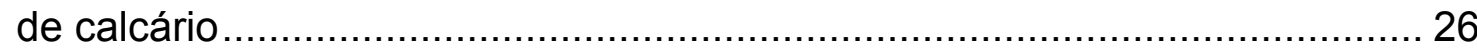

3.2.2 Confecção do mapa de prescrição de calcário ..................................... 26

3.2.3 Desenvolvimento do programa de controle do sistema ........................ 28

3.2.4 Sistema simulador do mecanismo dosador da distribuidora

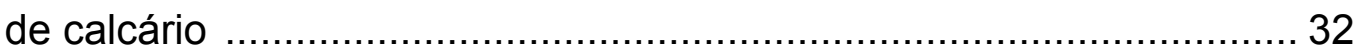

3.2.5 Sistema de controle automático montado na distribuidora

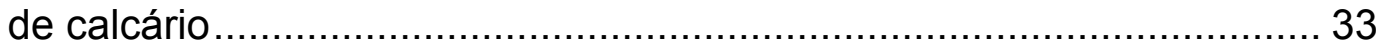

3.2.6 Ensaios para caracterização da distribuidora de calcário

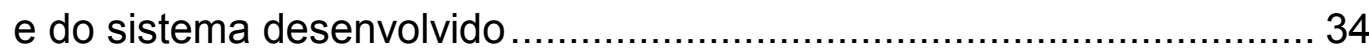

3.2.6.1 Caracterização da distribuição transversal ...................................... 34

3.2.6.2 Ensaio para determinação do tempo de resposta

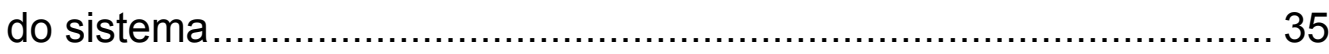

3.2.7 Ensaio de verificação da quantidade de calcário efetivamente aplicada no

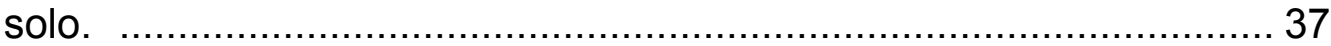

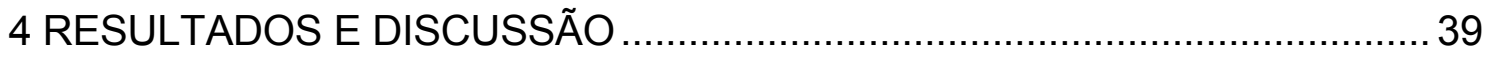

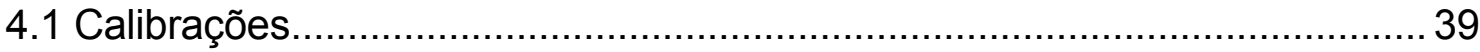

4.1.1 Calibração do conversor freqüência/tensão .......................................... 39

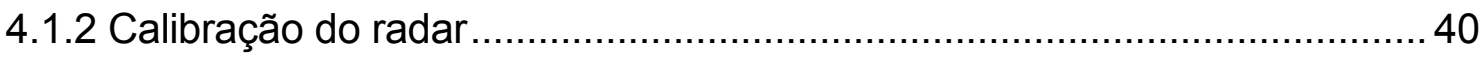

4.1.3 Calibração da vazão da distribuidora de calcário ..................................... 41

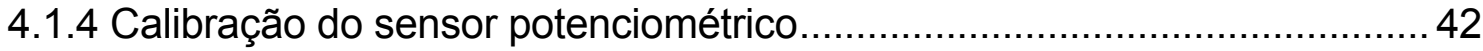

4.1.5 Calibração do mecanismo dosador da distribuidora de calcário ................. 43

4.2 Confecção do mapa de prescrição de calcário............................................. 44

4.3 Sistema simulador do mecanismo dosador da distribuidora de

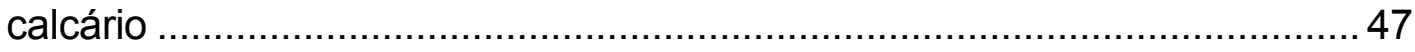

4.4 Ensaios para caracterização da distribuidora de calcário

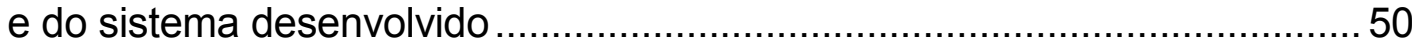

4.4.1 Caracterização da distribuição transversal ............................................... 50 
4.4.2 Ensaio para determinação do tempo de resposta do sistema 55

4.5 Ensaio de verificação da quantidade de calcário efetivamente

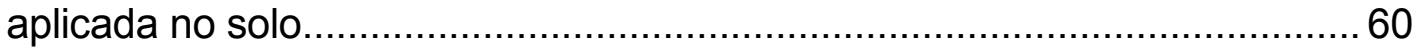

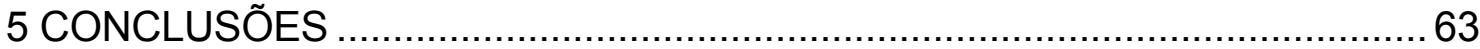

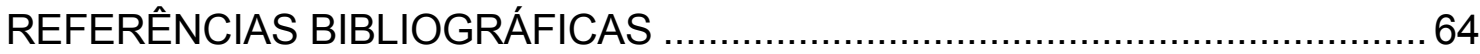




\section{LISTA DE FIGURAS}

Página

1 Ilustração do conceito da aplicação localizada de insumos, segundo GOERING (1992) ................................................................ 09

2 Distribuidora de fertilizante e corretivos agrícolas, modelo DCA5500 RD ......16

3 Esquema do DGPS utilizado............................................................ 17

4 Equipamentos eletrônicos: (a) Interface de potência para motor de passo;

(b) Motor de passo; (c) Transdutor potenciométrico; (d) Radar.

5 Conversor analógico digital: (a) Esquema do circuito elétrico;

(b) Vista geral do conversor A/D montado numa placa final

6 Conversor Freqüência Tensão: (a) Esquema do circuito elétrico;

(b) Vista geral do conversor F/V montado numa placa definitiva

7 Equipamentos montados na distribuidora de calcário: a) Motor de passo;

b) Interface de potência para acionar motor; c) Sensor potenciométrico;

d) Baterias 
8 Montagem dos equipamentos no trator: a) Estrutura montada no trator para armazenar os equipamentos; b) Computador portátil; c) Monitor DGPS; d) Interface contendo conversores A/D e F/V

9 Ensaio para determinação da equação de calibração da distribuidora de calcário 25

10 Disposição dos 60 coletores utilizados no ensaio de distribuição transversal

11 Disposição dos coletores para o ensaio de tempo de resposta 36

12 Ensaio para verificar a quantidade de calcário aplicada no solo 38

13 Dados relacionando freqüência e tensão para aferição da linearidade do conversor freqüência/tensão

14 Curva de calibração do radar

15 Curva de calibração da vazão da distribuidora de calcário 41

16 Curva de calibração do sensor potenciométrico 43

17 Curva de calibração do mecanismo dosador da distribuidora de calcário... 44

18 Mapa de prescrição de calcário simulado para área de estudo 45

19 Mapa de prescrição para dosagens de 2000 e 3000 kg.ha-1 mostrando a gleba utilizada de $60 \mathrm{~m} \times 10 \mathrm{~m}$ 46 
20 Mapa de prescrição para dosagens de 2000 e $5000 \mathrm{~kg} \cdot \mathrm{ha}^{-1}$ mostrando

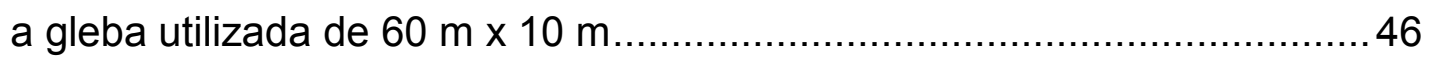

21 Mapa de prescrição para dosagens de 2000 e 5000 kg.ha-1 mostrando a gleba utilizada de $60 \mathrm{~m} \times 10 \mathrm{~m}$

22 Sistema simulador do mecanismo dosador montado em um trator

23 Curva de calibração do mecanismo dosador 49

24 Perfil de distribuição transversal para as dosagens de 2000, 3000 e 5000 kg.ha ${ }^{-1}$ de calcário

25 Resultados simulados do coeficiente de variação em função da largura efetiva de trabalho para os sistemas de percurso continuo, direito e esquerdo para cada dosagem de calcário

26 Faixa de deposição longitudinal para o tratamento com dosagem inicial de $2000 \mathrm{~kg} \cdot \mathrm{ha}^{-1}$, seguida de $3000 \mathrm{~kg} \cdot \mathrm{ha}^{-1}$ e novamente $2000 \mathrm{~kg} \mathrm{ha}^{-1}$; as linhas vermelhas verticais representam os pontos de mudança de dosagem

27 Faixa de deposição longitudinal para o tratamento com dosagem inicial de $3000 \mathrm{~kg} \cdot \mathrm{ha}^{-1}$, seguida de $5000 \mathrm{~kg} \cdot \mathrm{ha}^{-1}$ e novamente $3000 \mathrm{~kg} \cdot \mathrm{ha}^{-1}$; as linhas vermelhas verticais representam os pontos de mudança de dosagem 
28 Faixa de deposição longitudinal para o tratamento com dosagem inicial de $2000 \mathrm{~kg} \cdot \mathrm{ha}^{-1}$, seguida de $5000 \mathrm{~kg} \cdot \mathrm{ha}^{-1}$ e novamente $2000 \mathrm{~kg} \mathrm{ha}^{-1}$; as linhas vermelhas verticais representam os pontos

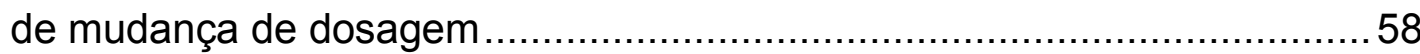

29 Distribuição de nove lonas plásticas na área referente ao mapa de prescrição. 


\section{LISTA DE TABELAS}

Página

1 Dados relacionando vazão $\left(\mathrm{kg} . \mathrm{s}^{-1}\right)$ com ponto de regulagem para obtenção da curva de calibração da máquina

2 Coeficientes de variação (\%) para largura efetiva de $5 \mathrm{~m}$...........................54

3 Síntese dos resultados do ensaio para obtenção do tempo de resposta em função das mudanças de dosagem

4 Dados comparando a quantidade $(\mathrm{kg})$ desejada e a obtida no ensaio de verificação da quantidade de calcário efetivamente aplicada no solo para as dosagens de $2000 \mathrm{~kg}^{\mathrm{h}} \mathrm{ha}^{-1}$, $3000 \mathrm{~kg} \cdot \mathrm{ha}^{-1}$ e $5000 \mathrm{~kg} \cdot \mathrm{ha}^{-1}$ 


\title{
DESENVOLVIMENTO DE UM SISTEMA DE APLICAÇÃO LOCALIZADA DE CALCÁRIO A TAXAS VARIÁVEIS
}

\author{
Autor: DOMINGOS GUILHERME PELLEGRINO CERRI \\ Orientador: Prof. Dr. LUIZ ANTONIO BALASTREIRE
}

\section{RESUMO}

As distribuidoras de calcário convencionais existentes no mercado são projetadas para distribuir o calcário em doses constantes, sem levar em consideração a variabilidade espacial existente no terreno. A presente pesquisa teve como objetivo, projetar e construir um sistema de aplicação localizada de calcário a taxas variáveis. Este sistema, possibilita a distribuição diferenciada de calcário no solo. Isto é possível porque as coordenadas geográficas da distribuidora de calcário são obtidas através do Sistema de Posicionamento Global Diferencial - ("Differential Global Positioning System" - DGPS) e, essas coordenadas, juntamente com as informações de velocidade da máquina e um mapa de prescrição da quantidade de calcário para cada ponto da área, são transferidas para um microcomputador que regula automaticamente a máquina, para aplicar a quantidade adequada de calcário que o terreno deve receber. A distribuição deste insumo no solo foi regulada por um dispositivo dosador, controlado por um motor de passo. Este recebe os impulsos elétricos provenientes de uma interface de potência, controlada pelo microcomputador. A confirmação do posicionamento do dispositivo dosador foi feita através de um sensor potenciométrico. Utilizou-se a linguagem de programação $\mathrm{C}++$ para 
confeccionar o programa de controle do sistema, o qual foi submetido a ensaios para avaliar sua acurácia. No ensaio para determinação do tempo de resposta pode-se observar que transições de maior dosagem para menor, o tempo de resposta foi menor do que para transições de menor dosagem para maior. Nos ensaios de verificação da quantidade de calcário efetivamente aplicada no solo, o erro observado entre quantidade desejada e a realmente aplicada não ultrapassou $3 \%$. Através dos resultados obtidos nos ensaios, pode-se concluir que o sistema está funcionando de acordo com o proposto. 


\title{
DEVELOPMENT OF A VARIABLE RATE LIME APPLICATION SYSTEM
}

\author{
Author: DOMINGOS GUILHERME PELLEGRINO CERRI \\ Adviser: Prof. Dr. LUIZ ANTONIO BALASTREIRE
}

\section{SUMMARY}

Most of the conventional lime spreaders available in the Brazilian market distribute lime at fixed rates without considering the spatial variability feature of the field. The purpose of this study was to design and build a variable rate lime application system. The developed system calculates the geographic coordinates of the lime spreader position obtained by a Differential Global Positioning System (DGPS). These coordinates, information on the machine speed and a prescription map of the quantity of lime needed for each area within the field are transferred to a computer. The program in the computer automatically adjusts the position of the machine metering device using a step motor driven by electric impulses generated by an electronic interface. The metering device position was checked through potentiometric sensors. The C++ programming language was used to write the control program for the system, which was tested to evaluate its accuracy. The tests demonstrated a shorter response time when changing from larger to smaller application rates than when changing from smaller to larger rates. In the test to verify the amount of lime effectively applied on the soil, the observed error between the desired amount 
and the real amount applied did not exceed $3 \%$. The results of the tests indicate that the system operates according to the established goals. 


\section{INTRODUÇÃO}

Os corretivos agrícolas constituem insumos fundamentais na exploração agropecuária. Levando-se em consideração que a acidez excessiva é a condição desfavorável de reação do solo mais comum nos terrenos brasileiros, a correta aplicação destes assume particular significado, tanto pela forma como as plantas respondem à essa prática como pelos custos envolvidos na lavoura (Mielniczuk, 1983).

A eficiência destes insumos no processo produtivo seja agrícola ou pecuário, é dependente da qualidade do corretivo e da forma como este é aplicado ao solo. Caso haja falhas em qualquer um destes fatores, esta etapa fica comprometida.

Linsley \& Bauer citados por Goering (1993) apresentaram em 1929, a circular no. 346 da Estação Experimental Agrícola da Universidade de Illinois (USA). Nessa circular os autores concluíram que: os requisitos de aplicação variavam bastante para um mesmo talhão em sua necessidade de calcário; e a necessidade de que fossem feitos testes sistemáticos e detalhados no campo, de forma que o calcário pudesse ser aplicado de acordo com a sua necessidade. Essa idéia permaneceu no esquecimento por muitos anos, até o momento em que a disponibilidade de microcomputadores, sensores e sistemas de posicionamento via satélite se tornaram disponíveis a custos acessíveis.

Surgiu desse modo, o conceito de Agricultura de Precisão, o qual é definido por Balastreire (1998) como um conjunto de técnicas que permite o gerenciamento localizado de uma cultura. 
Esta pesquisa teve por objetivo desenvolver um protótipo de um sistema automático para aplicação localizada de calcário a taxas variáveis, tendo como base um mapa de prescrição. Essa operação é realizada em tempo real e utiliza o Sistema de Posicionamento Global Diferencial - ("Differential Global Positioning System" - DGPS). 


\section{REVISÃO DE LITERATURA}

Tendo em vista a abrangência do assunto tratado, a presente revisão bibliográfica foi dividida em quatro partes, de maneira a facilitar a compreensão e a apresentação das informações. A primeira (2.1) aborda, de maneira geral, a variabilidade espacial dos solos. A segunda parte (2.2), trata do gerenciamento localizado de culturas e do conceito da aplicação localizada de insumos. $\mathrm{Na}$ terceira parte (2.3), são apresentados exemplos de utilização da aplicação localizada de insumos. Na última parte (2.4), são abordados o conceito e os tipos de distribuidores de fertilizantes existentes.

\subsection{Variabilidade espacial do solo}

As técnicas estatísticas empregadas na ciência agrícola tradicionalmente pressupõem estacionaridade e independência dos dados. Propriedades do solo, no entanto, podem apresentar dependência espacial em escalas que variam da ordem de poucas moléculas a alguns quilômetros (White et al. 1997; Castrignano et al., 2000; Yang et al., 2001). Além disto, é importante constatar que o solo é resultante da ação de alguns fatores que atuam em larga escala e cujo efeito é alterado por fatores que atuam em escalas menores, em diferentes níveis de superposição de efeitos, o que proporciona um caráter hierárquico para a estrutura de variação das propriedades no espaço (Gonçalves, 1997; Goovaerts, 1999; Chevallier, 2000).

As propriedades do solo, além de variarem no espaço, podem variar no tempo, para cada posição no espaço (Bernoux, 1998a e 1998b). Esta variação, 
decorrente da ação de agentes naturais, assim como da ação do homem, deve se manifestar com maior intensidade em algumas propriedades que em outras (Bragato \& Primavera,1998; Burke et al., 1999; Slot et al., 2001).

A variabilidade das propriedades do solo tem sido abordada por vários autores, sendo atribuída a diversos fatores, tais como, características do material de origem e os fatores de formação, os quais não atuam pontualmente, mas sim segundo um determinado padrão.

Peck and Melsted (1973) amostraram, em uma grade sistemática de 25,2 x 25,2 metros, o solo de duas áreas de 16,2 hectares e encontraram valores de $\mathrm{pH}$ médio de 6,6 e 6,2 para as duas áreas. Porém, o pH para estas áreas variou de 5,5 a 8,0 .

Mapa e Kumaragamage (1996) estudaram a variabilidade espacial de parâmetros físicos e químicos de um solo tropical, usando uma malha com espaçamento de $5 \mathrm{~m}$ e, próximo ao centro, tomaram uma "janela", correspondente a uma quadrícula de $5 \times 5 \mathrm{~m}$ e amostraram intensamente a cada $1 \mathrm{~m}$. Constataram que o $\mathrm{pH}$, apesar de apresentar o menor coeficiente de variação ajustou-se a uma distribuição log-normal. $\mathrm{O}$ pH não apresentou semivariograma estruturado e o efeito pepita foi superior a $50 \%$ da variabilidade total. O ajuste dos modelos foi feito por regressão, minimizando a soma de quadrados dos desvios. Os autores sugerem manejo diferenciado nas subáreas, de acordo com os mapas de valores das propriedades, obtidos por meio de krigagem em blocos.

Gonçalves (1997) mediu o pH, a matéria orgânica, a acidez trocável, o P disponível e as bases trocáveis em uma malha de espaçamento variável, de forma a abordar as variações em micro e em macroescala. Embora os resultados demonstrem baixa variabilidade do $\mathrm{pH}$ em relação às outras propriedades, os autores enfatizavam que o conhecimento do padrão de variabilidade permitia a identificação de padrões de amostragem adequados para pesquisas futuras. 
Na Itália, Castrignano et al. (2000) estudaram a relação espacial entre algumas propriedades físico-químicas usando geoestatística. $O$ trabalho foi conduzido em uma área de 4 ha, onde foram coletadas amostras de solo nas profundidades $0-10$ e 10-30 cm, para as análises de $\mathrm{pH}$, de capacidade de troca de cátions, $\mathrm{N}$ total, $\mathrm{K}$ e $\mathrm{Na}$. Os resultados analíticos foram submetidos à análise estatística clássica e análise geoestatística.

Yang et al. (2001) aplicaram ácido fosfórico como estratégia para recuperação de solos contaminados com chumbo. Sabe-se que o $\mathrm{pH}$ do solo influencia diretamente na disponibilidade deste elemento. Por tal motivo, os autores necessitaram conhecer a variabilidade espacial do $\mathrm{pH}$ em microescala e compararam a análise de variância convencional com a espacial. O pH do solo foi medido utilizando microeletrodos em intervalos de $1 \mathrm{~cm}$, no sentido vertical e horizontal, em amostras de terra com dimensão de $10 \times 10 \times 2,5 \mathrm{~cm}$. Os resultados desta pesquisa mostraram que a adição de ácido fosfórico propiciou a diminuição significativa do $\mathrm{pH}$ do solo e aumentou a variabilidade espacial total na zona medida. Os autores verificaram que a variabilidade espacial do $\mathrm{pH}$ na direção vertical diferiu significativamente, mas isso não ocorreu para a direção horizontal.

Yanai et al. (2001) determinaram o pH, a capacidade de troca de cátions, o carbono total, o nitrogênio total, a relação $\mathrm{C} / \mathrm{N}$, o fósforo disponível, o $\mathrm{N}$ inorgânico, o N mineralizável, além do $\mathrm{Ca}, \mathrm{Mg}, \mathrm{K}$ e Na em 100 amostras de solo coletadas em uma área de $50 \times 100$ m cultivada com arroz. A análise geoestatística indicou moderada a alta dependência espacial para as propriedades do solo exceto para o conteúdo de nitrogênio inorgânico. Uma dependência espacial de 20-30 m foi encontrada para $\mathrm{pH}$, capacidade de troca de cátions, carbono total, nitrogênio total e $\mathrm{Na}$. Uma dependência espacial de $40 \mathrm{~m}$ foi observada para fósforo disponível, $\mathrm{N}$ mineralizável, Ca e Mg. Já a relação $\mathrm{C} / \mathrm{N}$ e conteúdo de $\mathrm{K}$ apresentaram dependência espacial com alcance de 50-60 m. A análise multivariada em combinação com geoestatística 
possibilitou explicar $65 \%$ da variação não-aleatória ou da estrutura espacial como fatores determinantes para a obtenção da produção dos grãos de arroz.

A variabilidade espacial de propriedades do solo e a distribuição espacial de plantas daninhas no delta do Mississipi (EUA) foram estudadas através da utilização da geoestatística por Gaston et al. (2001). Amostras de solos foram coletadas através de uma malha regular de $60 \mathrm{~m}$ em uma área de 50 ha. Determinou-se o pH, o carbono orgânico, a textura, a umidade e a atividade microbiana do solo. A atividade microbiana mostrou limitada dependência espacial. Já com relação ao $\mathrm{pH}$, carbono orgânico e textura, os semivariogramas foram bem descritos com modelos esféricos. Apesar de apresentar pouco alcance $(<60 \mathrm{~m})$ a variabilidade foi alta, com dependência espacial excedendo os $120 \mathrm{~m}$.

Para se utilizar os conceitos da Agricultura de Precisão existe a necessidade de se utilizar métodos de cálculo e gerenciamento da variabilidade do solo. No entanto, com os conhecimentos existentes, as atuais grades de amostragem e técnicas de mapeamento dos atributos do solo, podem não ser adequadas. Por esta razão, Adamchuk et al. (1999) desenvolveram um sistema de amostragem automatizado de medidas de $\mathrm{pH}$ do solo em tempo real. $\mathrm{O}$ sistema determina o pH enquanto retira as amostras do solo. Não havendo a necessidade de enviar as amostras para um laboratório, possibilita aos pesquisadores que retirem um maior número de amostras e assim conseqüentemente representem melhor a variabilidade do $\mathrm{pH}$ do solo.

Do que foi apresentado pode-se sugerir que a quantificação da variabilidade espacial é útil por dois motivos: O primeiro é que o conhecimento dos erros associados ao modelo permite avaliar a qualidade dos resultados, definindo se estes atendem ao esperado, e se a qualidade é superior à necessária. Neste caso, nos próximos trabalhos, pode-se adotar uma amostragem menos intensa, reduzindo custos. Por outro lado, a qualidade pode ser inferior à necessária. Neste caso, talvez seja necessário coletar mais dados, calibrar melhor o modelo, usar melhor o modelo, trabalhar em uma resolução 
espacial diferente ou até mesmo escolher melhor um método de predição (Vieira, 1995; Ribeiro Junior, 1995; Bernoux, 1998a; Gaston et al., 2001; Yang et al. 2001). O segundo é no mapeamento dos atributos em questão, que para agricultura de precisão é a base para se gerar mapas de prescrição.

Tomando como referencia este segundo motivo Goering (1993) e Goering \& Hans (1993) partem do principio de que, levando-se em conta a variabilidade natural dos fatores de produção, pode-se aplicar apenas as quantidades efetivamente necessárias em cada ponto e que, portanto as técnicas de aplicação localizada de insumos se tornam muito importantes para uma agricultura rentável. Este conceito é evidenciado pelo trabalho de Borgelt (1994), o qual depois de amostrar o pH do solo de uma área de 8,8 hectares, concluiu que sem a utilização da técnica de aplicação localizada, 9 a 12\% dessa área receberia uma quantidade de calcário acima da recomendada e 37 a $41 \%$ receberia uma quantidade abaixo da recomendada.

\subsection{Gerenciamento localizado de culturas e conceito da aplicação localizada de insumos}

O conceito de gerenciamento localizado que surgiu em 1929, permaneceu no esquecimento, por muitos anos, até o momento em que os microcomputadores, sensores e sistemas de posicionamento terrestres ou via satélites se tornaram disponíveis a custos acessíveis (Colvin et al., 1996 e Stafford, 1996).

Outro fato que impulsionou a utilização desse conceito, foi a crescente preocupação com fatores ambientais, pois, com essa técnica, as aplicações de produtos químicos são efetuadas de modo a satisfazer a necessidade de cada ponto do talhão e com isso, diminui a probabilidade desses produtos serem lixiviados e contaminarem o ambiente (Blackmer \& Schepers, 1996.; Ostergaard, 1997.; Bouma,1998). 
Balastreire (1994), sugeriu que o conceito fosse designado por Aplicação Localizada de Insumos (ALI), uma vez que, os diversos insumos deveriam ser aplicados de forma localizada, em função dos requisitos da cultura a ser implantada, e das características de fertilidade de parcelas cujas dimensões deveriam se situar ao redor de $5 \times 5 \mathrm{~m}$. Afirma que o conceito de gerenciamento localizado de culturas pode ser estendido para o monitoramento de outras operações que não necessariamente aquelas de aplicações localizadas de insumos, como por exemplo, o monitoramento de operações de semeadura, de colheita ou de outras operações mecanizadas.

Schueller (1992) definiu a Agricultura de Precisão como um método de administração cuidadosa e detalhada do solo e da cultura para adequar as diferentes condições encontradas em cada ponto da lavoura, tendo em vista a desuniformidade intrínseca dos solos.

Para Goering (1993) a Agricultura de Precisão tem como meta final aplicar sementes, fertilizantes, e outros insumos variavelmente em cada talhão, nas taxas adequadas à produtividade do solo em cada ponto do talhão.

Segundo Searcy (1995) a Agricultura de Precisão é a tecnologia que possibilita modular a aplicação dos insumos agrícolas numa base pontual em resposta a necessidades altamente localizadas das plantas.

Rawlins (1996) diz que a Agricultura de Precisão é o conceito de casar os insumos com a capacidade de produção.

Balastreire (1998) sintetiza as definições dizendo que a Agricultura de Precisão é um conjunto de técnicas que permite o gerenciamento localizado de uma cultura.

Em uma visão mais voltada para os equipamentos Clark \& McGuckin (1996) e Strauss et al. (1998) dizem que a Agricultura de Precisão envolve sistemas automáticos, basicamente composto por microcontroladores, sensores e atuadores acoplados ao implemento agrícola pré-existente e interligado ao Sistema de posicionamento Global "Global Positioning System" - GPS. 
Goering ${ }^{1}$ citado por Balastreire (1998) discute os princípios básicos, para a utilização do conceito da aplicação localizada de insumos, conforme ilustra a Figura 1.

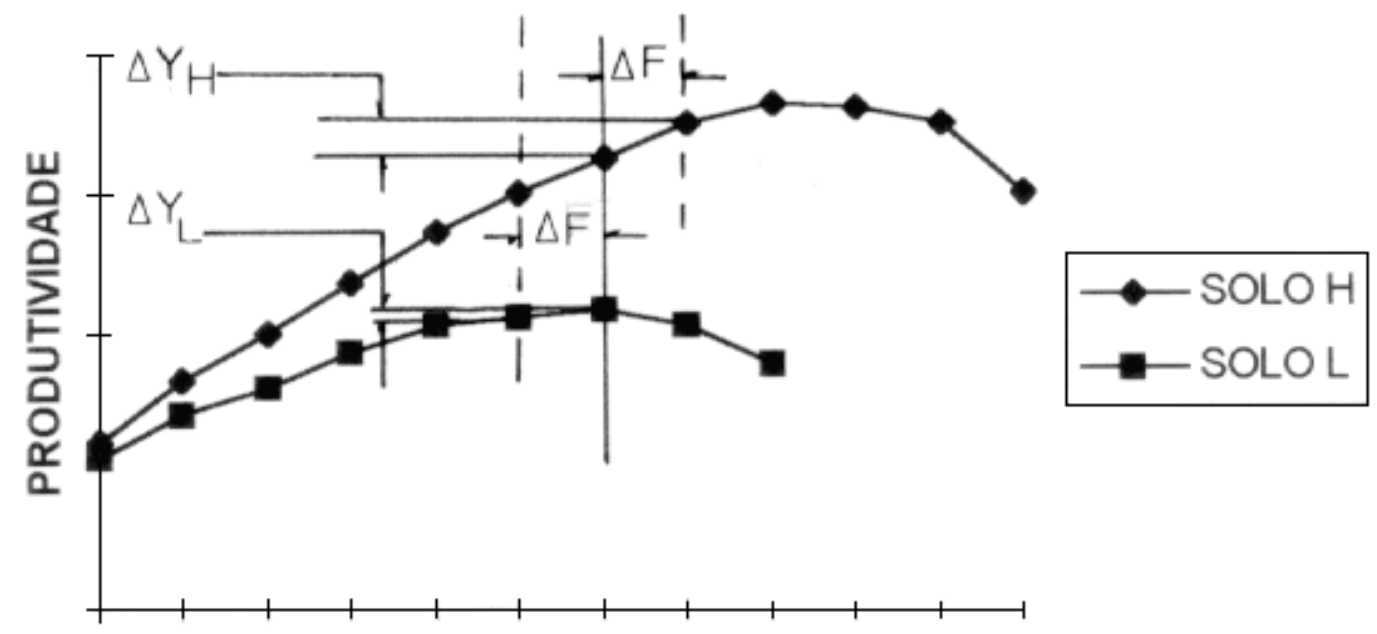

NÍVEL DE FERTILIDADE

Figura 1 - Ilustração do conceito da aplicação localizada de insumos, segundo Goering, citado por Balastreire (1998).

Na Figura 1, a curva superior se refere a um solo de alta fertilidade $(H), e$ a curva inferior a um solo de baixa fertilidade (L). Em ambos os casos, as curvas apresentam o formato característico de produtividades decrescentes. A linha vertical representa uma razão constante de aplicação. Na curva relativa ao solo L, esta razão é próxima ao limite superior, a partir do qual o solo apresentará toxicidade. Todavia, para o solo $\mathrm{H}$, a curva ainda está em seu ramo ascendente. Se o agricultor mudar de uma razão constante de aplicação para uma aplicação localizada, a razão de aplicação pode diminuir de $\Delta \mathrm{F}$ no solo $\mathrm{L}$, resultando em uma perda de produtividade da cultura $\triangle \mathrm{YL}$ naquele solo. Se o mesmo incremento na razão de aplicação for utilizada no solo $H$, a produtividade terá um acréscimo $\Delta \mathrm{YH}$. Como a perda $\Delta \mathrm{YL}$ é menor que o ganho $\Delta \mathrm{YH}$, a utilização do conceito de aplicação localizada (ALI) resultará em um

\footnotetext{
${ }^{1}$ GOERING, C.E. How much and where. Agricultural Engineering, v.73, p.13-15, 1992.
} 
ganho líquido para cada incremento de fertilizante desviado do solo de baixa para o de alta produtividade. Desta forma o objetivo final da aplicação localizada de insumos, é colocar sementes, fertilizantes e outros insumos de forma variável em cada campo, nas razões mais adequadas para a produtividade do solo em cada ponto do mesmo.

\subsection{Exemplos de utilização da técnica de aplicação localizada de insumos}

Searcy (1989) utiliza como exemplo das vantagens da aplicação localizada, o uso de nitrogênio na cultura de algodão no Texas. Utilizando valores típicos para a região e assumindo que o campo tem $10 \%$ da área com excesso e $20 \%$ com falta de nitrogênio a perda devida a adubação incorreta seria de US\$ 338 para uma área de 100 acres. Mesmo que a utilização da aplicação localizada provocasse um acréscimo de custo de $50 \%$, o lucro líquido ainda seria da ordem de US\$1,88.acre ${ }^{-1}$. Além desse retorno deve-se salientar que uma aplicação otimizada do nitrogênio poderia reduzir a possibilidade de poluição da água subterrânea.

Neuhaus \& Searcy (1993) desenvolveram um sistema para aplicação de fertilizante e semeadura a partir de equipamento de mercado adaptado, mas não conseguiram uma acurácia satisfatória para o controle do fertilizante. Já para sementes o sistema apresentou um coeficiente de variação de $5 \%$ para os espaçamentos entre sementes a uma velocidade acima dos $6,9 \mathrm{~km} \cdot \mathrm{h}^{-1}$.

Balastreire (1993) descreve um sistema desenvolvido em um projeto de pesquisa na Texas A\&M University, o qual utiliza um microcomputador SBC53 no trator, e um microprocessador Motorola na máquina para aplicação localizada de nitrogênio no plantio de milho. O posicionamento do conjunto no campo era determinado por um sistema de triangulação utilizando emissores e receptores de microondas. O sistema, ainda, era formado por uma placa de comunicação serial quádrupla, um sistema de medida de distância utilizando microondas, um radar para medida de velocidade de deslocamento no campo, 
um sistema de memória de dados com cartão magnético e, finalmente, um teclado e display para entrada e visualização dos dados.

Monson (1995) descreve um sistema de aplicação tanto para insumos sólidos quanto para líquidos. Para realização dessa pesquisa, os autores acoplaram o sistema de controle desenvolvido num veículo aplicador equipado com tanques suficientes para aplicar simultaneamente até nove produtos secos, ou até seis produtos líquidos.

Ess et al. (1996) desenvolveram um protótipo de um sistema para aplicação localizada de esterco líquido de origem suína. Para realização desta pesquisa os autores basearam-se num distribuidor de esterco liquido comercial, acoplado a um computador portátil para medição dinâmica do peso do depósito com células de carga. Para permitir o controle automático da saída do produto baseado em mapas, o sistema de controle eletrohidráulico foi interligado a um receptor GPS.

Nos Estados Unidos, Bongiovanni \& DeBoer (1998) realizaram um estudo para avaliar a rentabilidade da aplicação a taxas variáveis de calcário em culturas de soja e milho. Os autores consideraram duas estratégias de aplicação. A primeira usava a recomendação agronômica e a segunda regras econômicas. Os resultados desta pesquisa evidenciaram que houve um aumento de produção nestas culturas e que na primeira estratégia ocorreu um aumento de retorno anual médio de US $\$ 2,93$. acre $^{-1}$ e na segunda um aumento de US\$7,91.acre -1 $^{-1}$

Skotnikov \& McGrath (1998) propuseram soluções técnicas para evitar que máquinas que aplicam insumos em taxas variáveis e que possuem diversos reservatórios para diferentes insumos parem suas atividades no campo devido ao esvaziamento de um de seus compartimentos. Estas paradas reduzem o desempenho operacional e aumentam o custo operacional, significativamente. Assim, a fim de melhorar a performance e a capacidade operacional dos equipamentos de aplicação de insumos agrícolas, os autores propõem 
mudanças no tamanho dos compartimentos e sistemas automatizados de gerenciamento.

Fulton et al. (1999) trabalharam com uma máquina equipada com DGPS e um sistema de aplicação a taxas variáveis avaliando a máquina sob os sistemas de aplicação uniforme e variada. Para tal, montaram uma malha de $13 \times 13$ coletores e seguiram os procedimentos da norma ASAE S341.2. Os autores encontraram que o tempo de resposta do equipamento para alterações na dosagem foi de $8.2 \mathrm{~s}$, considerado bom, mas que a distribuição longitudinal carecia de melhorias na uniformidade.

Stevens et al. (1999) realizaram testes de campo em Missouri, USA para determinar a viabilidade econômica da aplicação localizada de calcário em algodão. Os autores observaram que a produtividade do algodão foi significativamente maior usando a aplicação variável de calcário em relação a aplicação uniforme, gerando um aumento no rendimento econômico de US\$ 11,00 por acre.

\subsection{Distribuidoras de fertilizantes e corretivos}

Os corretivos agrícolas constituem insumos fundamentais na exploração agropecuária (Raij,1991).

A eficiência destes insumos no processo produtivo seja agrícola ou pecuário, é dependente da qualidade do corretivo e da forma como este é aplicado no solo. Caso haja falhas em qualquer um destes fatores, esta etapa encontra-se comprometida (Santa Catarina, 1994). Assim, para os produtores, a necessidade de se conhecer os diferentes tipos de máquinas para aplicação de adubos e corretivos existentes no mercado se torna muito importante.

Mialhe (1996) denomina máquinas para aplicação de adubos e corretivos aquelas destinadas a promover a dosagem e distribuição de adubos e corretivos no solo, como operação singela ou conjuntamente com a semeadura ou o cultivo. 
Gadanha Jr. et al. (1991) citaram as principais máquinas utilizadas para aplicação de fertilizantes e corretivos sólidos como a aplicadora de fertilizante e corretivos a lanço, de linhas conjugadas, de linhas individuais e a transportadora aplicadora autopropelida de fertilizantes e corretivos.

Mialhe (1986) diz que as máquinas de aplicação a lanço são constituídas basicamente por um chassis, reservatório e mecanismos dosadores e distribuidores do produto. Estes últimos são os principais mecanismos dos distribuidores a lanço, pois têm a função de dosar e distribuir a quantidade préselecionada do produto aplicado. O acoplamento pode ser feito através do engate de três pontos para as máquinas montadas e por meio da barra de tração para as máquinas de arrasto. $O$ acionamento dos mecanismos podem ser efetuados pela tomada de potência do trator ou pela roda de terra do equipamento. E que a aplicação do produto a lanço é executada por mecanismos distribuidores dos tipos centrifugo ou pendular.

Para Balastreire (1987) os distribuidores centrífugos se caracterizam por apresentarem um ou dois rotores constituídos ou não de aletas fixas para o lançamento dos insumos. Mialhe (1996) define distribuidores pendulares como sendo mecanismos que distribuem o fertilizante ou corretivo dosado através de movimento pendular e é constituído de um tubo horizontal cujo movimento oscilante horizontal determina o caminho das partículas ao longo do seu comprimento pela ação da inércia e o lançamento em arco.

Segundo Parish (1995) aplicadores pendulares apresentam melhor uniformidade de distribuição do que os aplicadores centrífugos.

Mialhe (1996) discute que para se ter um bom planejamento de aplicação é essencial a avaliação da deposição cumulativa, que é o recobrimento entre as faixas de deposição de passadas adjacentes de forma a tornar a dosagem de aplicação uniforme em cada ponto de toda a extensão do terreno. Esta avaliação depende do tipo de percurso adotado no manejo da máquina. Os dois circuitos mais comuns são o continuo e o vai e vem. No circuito continuo o lado esquerdo, de parte da faixa de deposição numa passada, recobre o lado direito 
de parte da faixa de deposição da passada anterior. No circuito vai e vem o lado direito de parte da faixa de deposição numa passada, recobre o lado direito de parte da faixa de deposição da passada anterior. O mesmo acontece também com o lado esquerdo. 


\section{MATERIAL E MÉTODOS}

\subsection{MATERIAL}

Para o desenvolvimento do sistema de aplicação localizada de calcário a taxas variáveis foi necessária a utilização de equipamentos agrícolas, de sistema de posicionamento, de equipamentos eletrônicos, de programas computacionais e de outros materiais para realização dos ensaios.

\subsubsection{Equipamentos Agrícolas}

Utilizou-se uma distribuidora de fertilizantes e corretivos agrícolas, de arrasto, modelo DCA $5500 \mathrm{RD}$, fabricada pela Marchesan Implementos e Máquinas Agrícolas "Tatu" S.A. A distribuidora é composta por um mecanismo dosador volumétrico, um distribuidor centrífugo formado por dois rotores horizontais girando em sentidos contrários e por um depósito tronco-piramidal com capacidade de carga de 2,3 metros cúbicos (Figura 2).

O acionamento da distribuidora de calcário foi realizado por um trator Massey Ferguson MF 5285. 


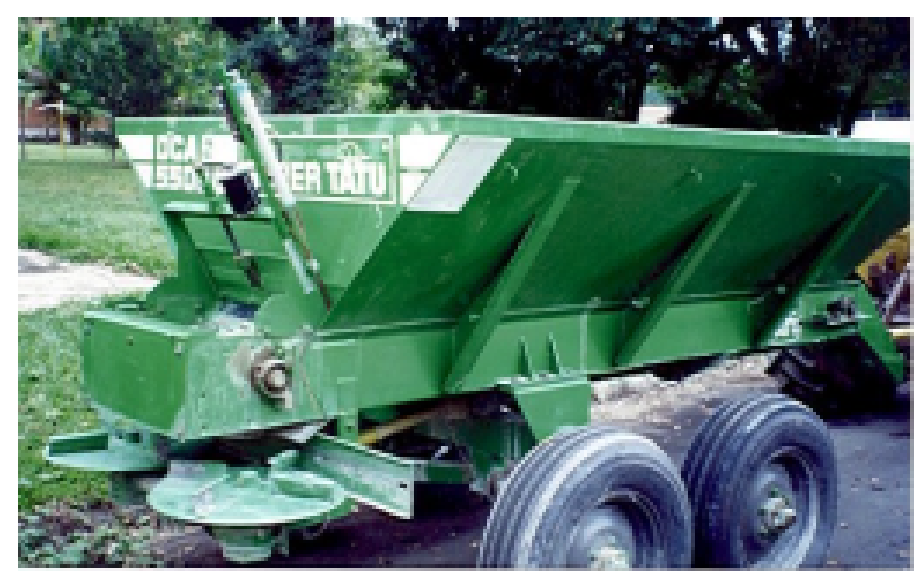

Figura 2 - Distribuidora de fertilizante e corretivos agrícolas, modelo DCA5500 RD.

\subsubsection{Sistema de Posicionamento}

Para o posicionamento no campo e o georeferenciamento dos pontos de controle da aplicação do produto, utilizou-se um DGPS, com correção em tempo real, composto por um receptor-base GPS da marca Ashtech, com 8 canais, um receptor móvel de 8 canais, da marca Ashtech, modelo AgNavigator, integrado a um microcomputador dedicado, baseado em um microprocessador Cyrix 486 de $66 \mathrm{MHz}$; um rádio da base com $35 \mathrm{~W}$ de potência e um rádio móvel com 2 W de potência, ambos da marca Pacific Crest.

O esquema do DGPS é aquele descrito por Balastreire (1998) cujo esquema, pode ser visto na Figura 3. 


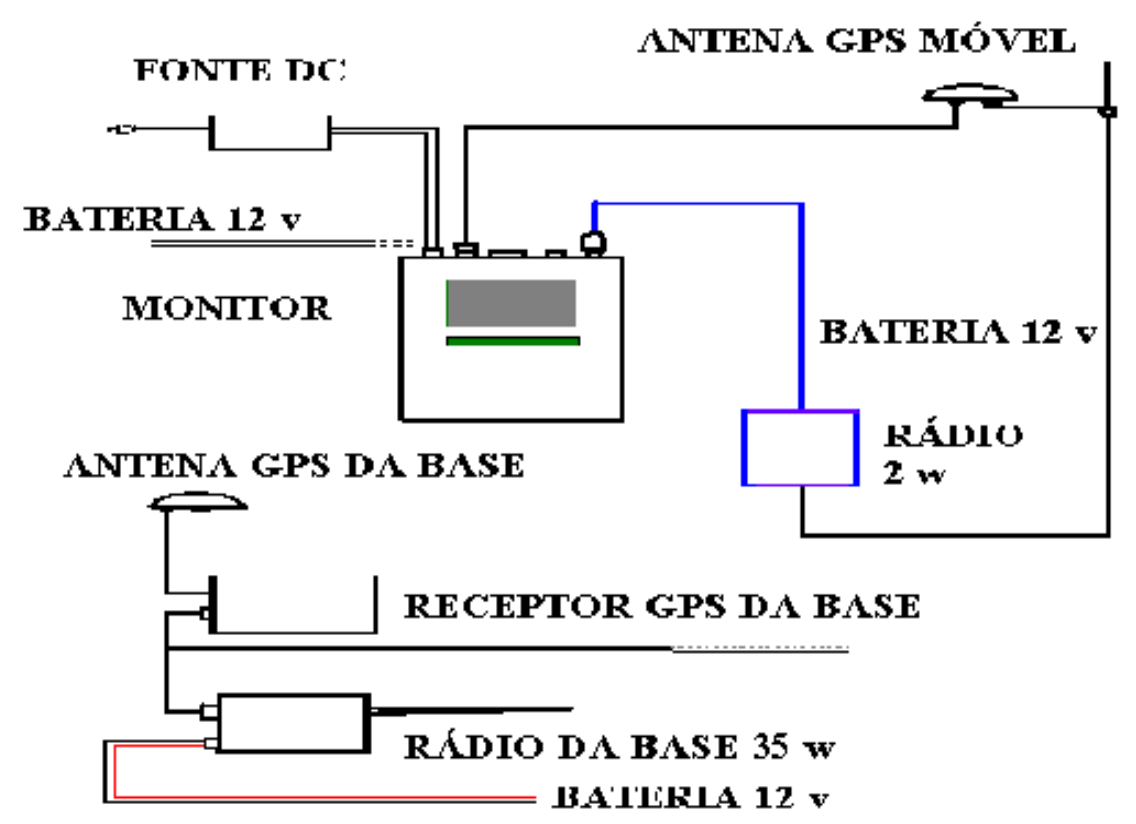

Figura 3 - Esquema do DGPS utilizado.

O sistema é complementado por uma unidade de processamento de sinais, composta por um microcomputador portátil Pentium $166 \mathrm{MHz}$, com interface de entrada/saída responsáveis pela leitura do DGPS e dos sensores de sinais e o envio de comandos para a interface de potência do motor de passo.

\subsubsection{Equipamentos eletrônicos}

A interface de potência ou controlador para motor de passo utilizado é da marca Applied Motion Products, modelo 7080 (Figura 4a). O motor de passo também é da marca Applied Motion Products, modelo 5034-350, com $34 \mathrm{~kg} \mathrm{~cm}^{-1}$ de torque, suficiente para o acionamento do mecanismo dosador (Figura 4b). 

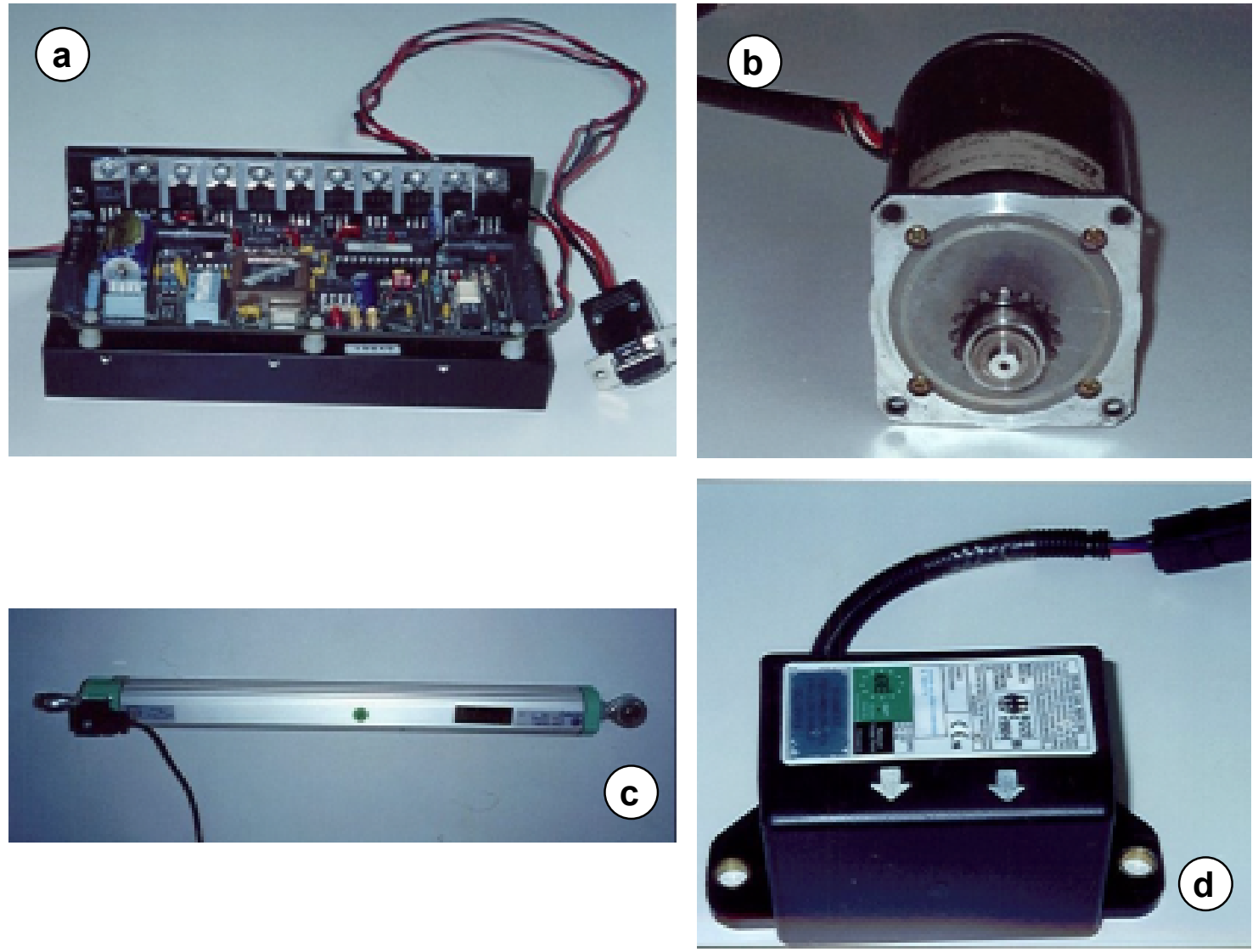

Figura 4 - Equipamentos eletrônicos: (a) Interface de potência para motor de passo; (b) Motor de passo; (c) Transdutor potenciométrico; (d) Radar.

Para indicação da posição de abertura do mecanismo dosador da máquina distribuidora de calcário, foi utilizado um transdutor potenciométrico de 5000 ohms (Figura 4c), cujo princípio de funcionamento baseia-se na variação de sua resistência elétrica (Parr, 1995).

Para indicação do deslocamento do conjunto trator e distribuidora no campo foi utilizado um radar da marca Philips, modelo RGSS-201 (Figura 4d).

Para indicação da posição de abertura do mecanismo dosador da máquina distribuidora de calcário e para indicação do deslocamento do conjunto trator/distribuidora no campo fez-se necessário a construção de um conversor analógico/digital. Este converte os sinais analógicos provenientes dos 
respectivos sensores em sinais digitais, os quais podem ser interpretados pelo programa de controle armazenado no microcomputador portátil utilizado.

Para a construção do conversor analógico digital utilizou-se o circuito integrado ADC0832, o qual suporta a leitura de 2 entradas analógicas que podem ser selecionadas através de um sinal originado do programa. Utilizou-se também, um regulador de tensão 7805 , o qual regula a diferença de potencial de entrada para 5 volts. Um esquema do circuito elétrico do conversor analógico/digital e sua respectiva montagem em uma placa definitiva podem ser vistos na Figura 5.

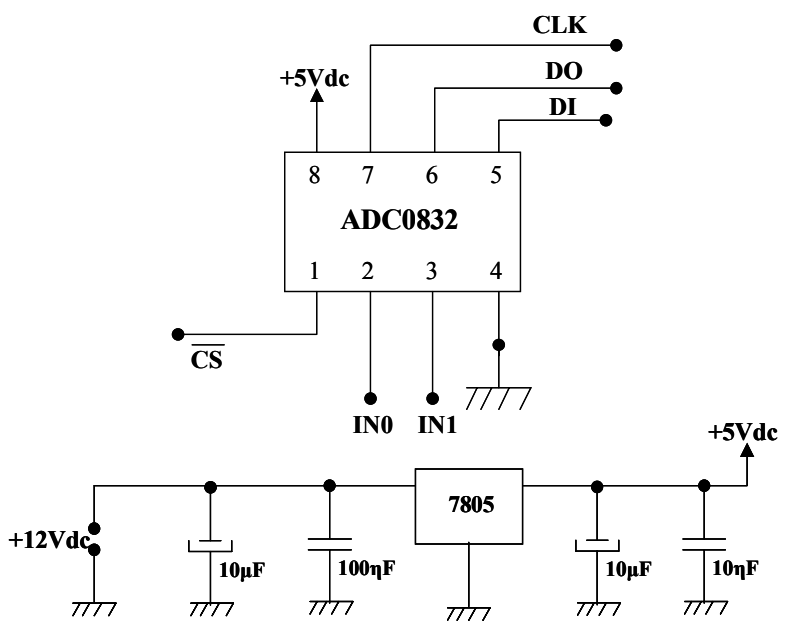

(a)

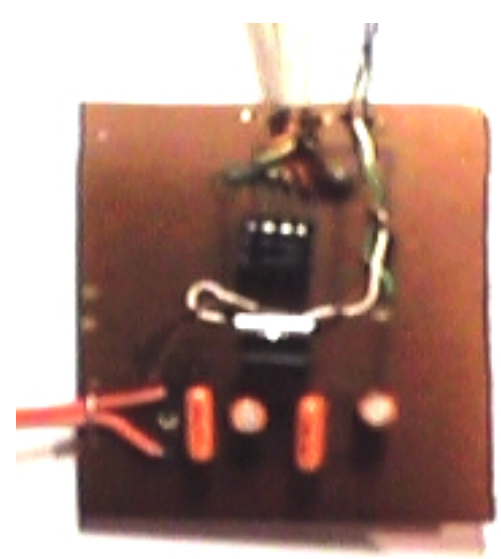

(b)

Figura 5 - Conversor analógico digital: (a) Esquema do circuito elétrico; (b) Vista geral do conversor A/D montado numa placa final.

Para possibilitar a leitura do radar (sensor de velocidade) fez-se necessário a elaboração de um circuito que convertesse, primeiramente, o sinal de freqüência emitida pelo sensor em forma de tensão, para que, posteriormente, através de um conversor $A / D$, pudesse ser interpretado pelo microcomputador. O circuito integrado utilizado foi o LM2907 da empresa 
National. A Figura 6 mostra o esquema do circuito elétrico do conversor freqüência tensão e a montagem dos componentes em uma placa definitiva.

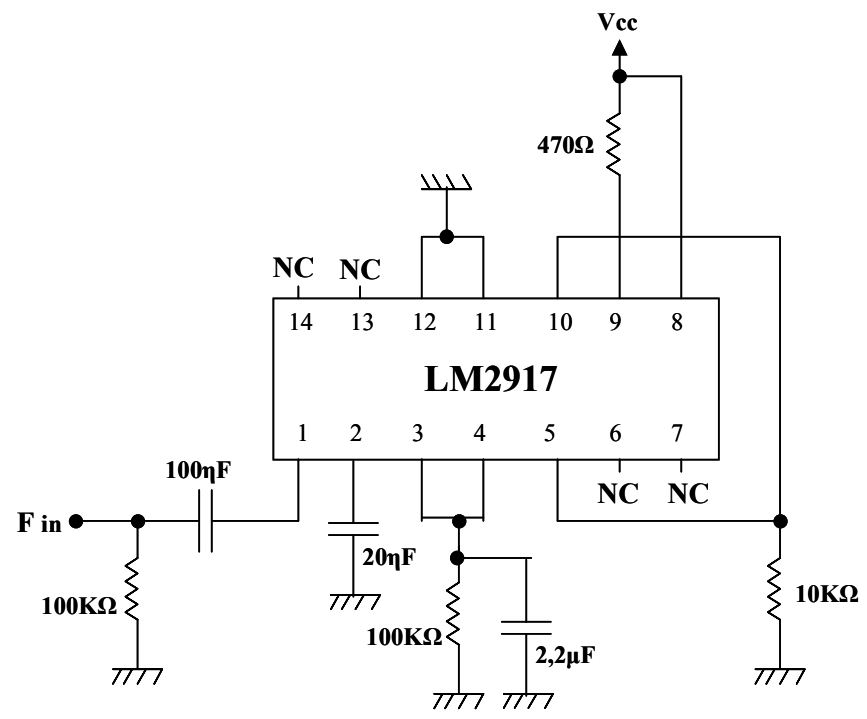

(a)

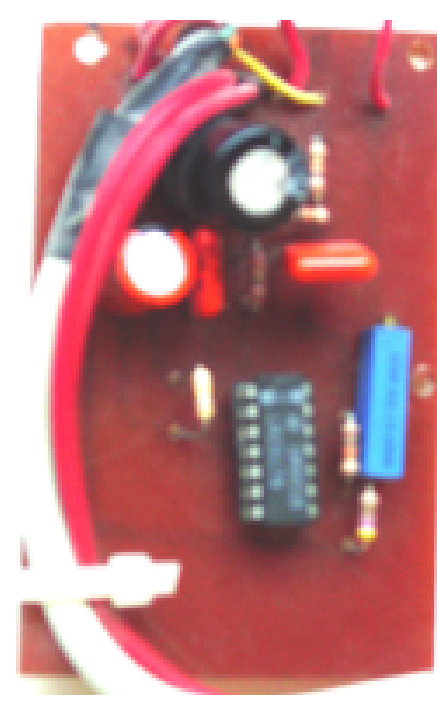

(b)

Figura 6 - Conversor Freqüência Tensão: (a) Esquema do circuito elétrico; (b) Vista geral do conversor F/N montado numa placa definitiva.

\subsubsection{Programas computacionais}

O programa SSToolbox 3.2.0.b da SSTools Development Group foi utilizado para a confecção do mapa de prescrição. Esse mapa é um arquivo eletrônico que integra dados georreferenciados com a recomendação da quantidade de insumo em função da localização no campo.

O programa Turbo $\mathrm{C}++3.0$ foi utilizado para desenvolver em linguagem de programação $\mathrm{C}++$, o programa de controle do sistema de aplicação localizada de calcário.

O programa Adulanço 2.1 (Molin et al., 1992) foi utilizado para realizar o cálculo do coeficiente de variação em função da largura efetiva simulada e assim, determinar qual é a largura efetiva de trabalho da distribuidora de calcário. 


\subsubsection{Outros materiais}

Para realização dos ensaios de caracterização da distribuidora de calcário e do sistema desenvolvido foram utilizados: coletores padronizados, com dimensões de 1,0 X 0,25 X 0,15 m (comprimento, largura e altura) para a coleta do calcário aplicado; sacos de papel para armazenar o calcário coletado em cada coletor; nove unidades de lona plástica medindo $10 \times 4 \mathrm{~m}$, para coletar - calcário aplicado no ensaio de verificação da quantidade de calcário efetivamente aplicada no solo; uma balança eletrônica de precisão Gehaka, com sensibilidade de $9,8 \times 10^{-5} \mathrm{~N}\left(1 \times 10^{-5} \mathrm{kgf}\right)$; uma célula de carga com resolução de $0,98 \mathrm{~N}(0,1 \mathrm{kgf})$ e capacidade de $9800 \mathrm{~N}$ (1000kgf), da marca Sodmex; um anemômetro da marca Minipa para medir a velocidade do vento; e um psicrômetro da marca Taylor para medir a umidade relativa do ar.

\subsubsection{Sistema de controle automático montado na distribuidora de calcário}

O sistema de dosagem automática de quantidade de calcário a ser aplicado pode ser visto na Figura 7 .
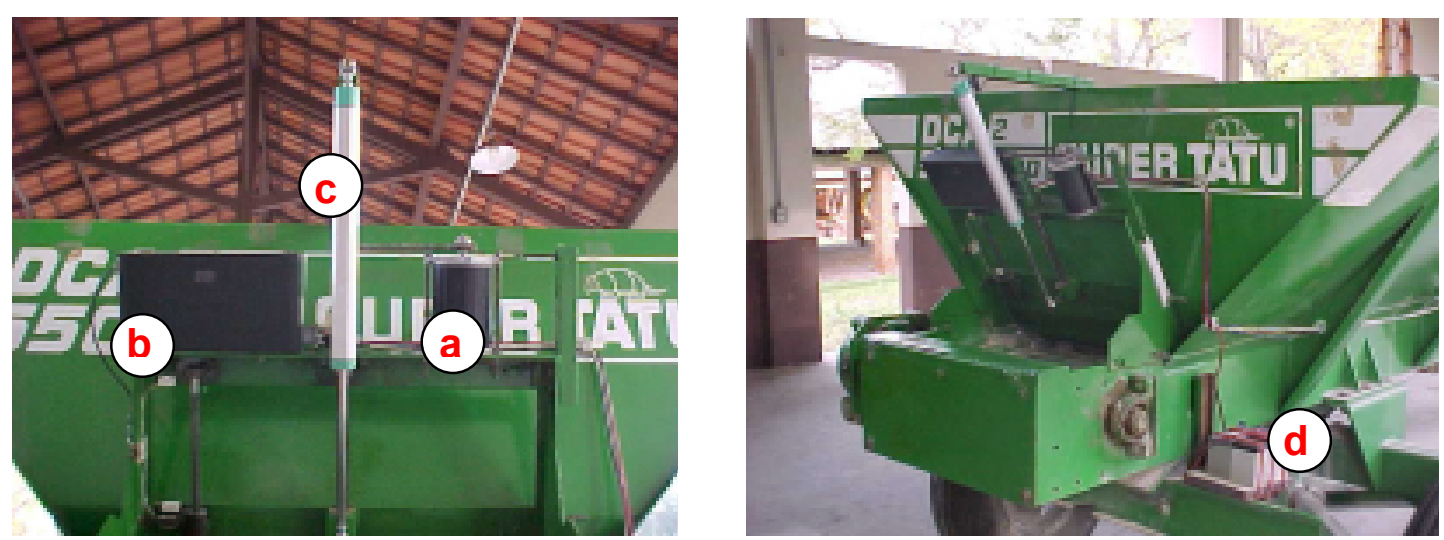

Figura 7 - Equipamentos montados na distribuidora de calcário: a) Motor de passo; b) Interface de potência para acionar motor; c) Sensor potenciométrico; d) Baterias. 
Para a montagem dos equipamentos como monitor do DGPS, computador portátil e caixa plástica contendo o conversor analógico/digital e freqüência/tensão, fez-se necessário a construção de um suporte de ferro e madeira, como mostra a Figura 8. Esta estrutura foi montada no lado direito do painel do trator MF5285.

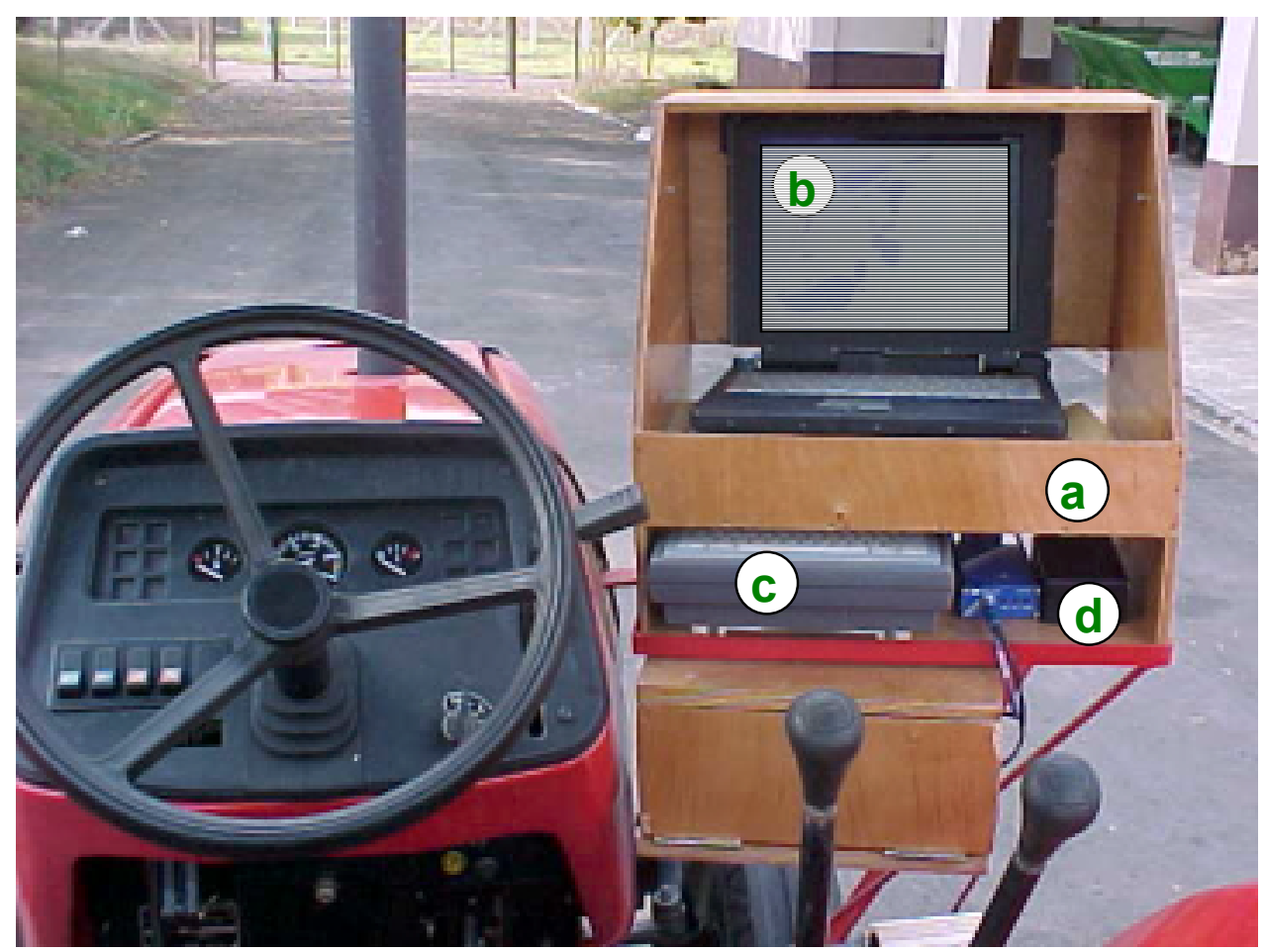

Figura 8 - Montagem dos equipamentos no trator: a) Estrutura montada no trator para armazenar os equipamentos; b) Computador portátil; c) Monitor DGPS; d) Interface contendo conversores A/D e F/V.

\subsection{MÉTODOS}

O sistema de aplicação localizada de calcário baseia-se no posicionamento da distribuidora de calcário no campo, através do DGPS, que fornece sua posição com acurácia aproximada de um metro. O programa desenvolvido e armazenado no microcomputador portátil gerencia a aquisição 
dos dados de posição e dos sinais referentes à velocidade de deslocamento do conjunto trator/distribuidora de calcário e do sensor de posição do mecanismo dosador. A partir do mapa de prescrição e da equação de calibração da distribuidora, é calculado o posicionamento real da máquina que é comparado com as posições existentes no mapa de prescrição.

A quantidade necessária de calcário que o terreno deve receber naquele local é tomada como a quantia do ponto da grade mais próximo ao ponto desejado, ou seja, a posição em que a distribuidora se encontra.

A abertura do mecanismo dosador é calculada para se obter a quantidade de calcário desejada. Essa abertura é posicionada através do motor de passo que recebe os impulsos elétricos provenientes da interface de potência, a qual é acionada através de sinais enviados pelo microcomputador portátil.A confirmação da posição do dosador é efetuada através do transdutor potenciométrico.

As diversas etapas do sistema de aplicação localizada de calcário a taxas variáveis estão descritas a seguir.

\subsubsection{Calibrações}

\subsubsection{Calibração do radar}

Nesta etapa desenvolveu-se um programa em linguagem $\mathrm{C}++$, com a finalidade de ler o sinal proveniente do radar e mostrar no monitor do microcomputador portátil o seu respectivo valor em forma de tensão. Para isso, acoplou-se o radar ao conversor freqüência/tensão, e este ao conversor analógico/digital, de modo que, através da saída paralela do microcomputador portátil, o sinal podia ser interpretado. A fim de possibilitar a sua calibração, o sistema foi devidamente adaptado ao trator. O procedimento utilizado para a calibração consistiu em cronometrar o tempo de deslocamento do trator em diferentes marchas, operando a 1900 rpm (540 rpm na tomada de potência - 
TDP) num percurso de 60 metros. Durante o percurso, o tratorista verificava, no monitor do microcomputador, qual era a tensão indicada. Assim, com os dados de velocidade obtidos pela divisão do percurso pelo tempo e com os seus respectivos valores de tensão pode-se fazer uma curva de calibração para o radar.

\subsubsection{Calibração da vazão da distribuidora de calcário}

As etapas para a realização da calibração foram efetuadas segundo a metodologia adotada por Mialhe (1996).

O primeiro passo para calibração da vazão da distribuidora de calcário foi abastecer o reservatório da máquina com $50 \%$ de sua carga máxima (Ruiz, 1999). O segundo passo foi retirar os discos de distribuição da máquina e acopla-la ao trator para seu acionamento. O último passo foi coletar o calcário em uma caixa de madeira por um período de trinta segundos para cada posição do mecanismo dosador (Figura 9). Uma vez que este tem um curso total de $0,17 \mathrm{~m}$, esta operação foi realizada a cada $0,02 \mathrm{~m}$ de abertura. A cada ponto de regulagem, a caixa com o material coletado era pesada com o auxilio de uma célula de carga. A partir dos dados coletados, determinou-se a curva de calibração de vazão da distribuidora de calcário. Foram realizadas quatro repetições para cada ponto de regulagem. 


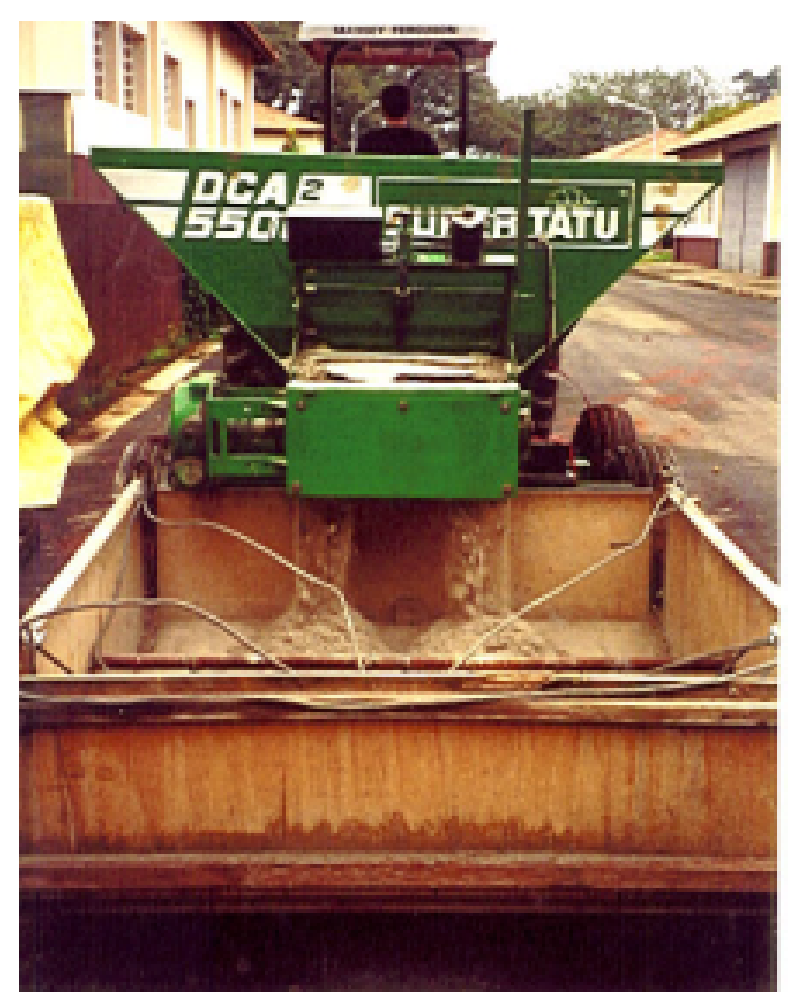

Figura 9 - Ensaio para determinação da equação de calibração da distribuidora de calcário.

\subsubsection{Calibração do sensor potenciométrico}

O mesmo programa desenvolvido no item 3.2.1.1 (Calibração do Radar) foi utilizado para a calibração do sensor potenciométrico. Este transdutor foi acoplado ao mecanismo dosador da distribuidora de calcário. E a cada $0,01 \mathrm{~m}$ de abertura, anotava-se o valor da tensão mostrada no monitor do microcomputador. Com os valores de abertura e tensão pôde-se determinar a curva de calibração do sensor potenciométrico. Esta equação foi utilizada no programa de controle para o cálculo da posição real do mecanismo dosador. 


\subsubsection{Calibração do mecanismo dosador da distribuidora de calcário}

A curva de calibração do mecanismo dosador foi obtida pela contagem do número de voltas necessárias no eixo do motor, para que este abrisse $0,01 \mathrm{~m}$ no mecanismo dosador da distribuidora de calcário. Este procedimento foi efetuado a cada $0,01 \mathrm{~m}$ num curso total de $0,17 \mathrm{~m}$. A partir desses valores pôdese gerar a equação de calibração da máquina, a qual relaciona número de voltas do motor com abertura do mecanismo dosador.

Essa equação foi utilizada pelo programa de controle desenvolvido (item 3.2.3) para acionar o motor de maneira a posicionar o dispositivo de abertura do mecanismo dosador.

\subsubsection{Confecção do mapa de prescrição de calcário}

Uma das fases necessárias para a aplicação localizada de insumos é o mapa de prescrição. Este mapa contém informações sobre as quantidades necessárias de insumos que cada ponto da área deve receber, levando-se em consideração diversos fatores que influenciam uma cultura como as análises de solo, a produtividade e o tipo de solo.

Para a realização dos ensaios de determinação do tempo de resposta da distribuidora de calcário foi necessária a elaboração de três mapas de prescrição de calcário. Para o ensaio de verificação da quantidade de calcário efetivamente aplicada ao solo elaborou-se um outro mapa de prescrição. Todos os mapas foram confeccionados utilizando-se o programa SSToolBox 3.2.0.b.

Para a realização deste ultimo mapa procedeu-se às seguintes etapas:

a) Escolha de uma área próxima ao laboratório de Instrumentação e Eletrônica do Departamento de Engenharia Rural - ESALQ/USP, em Piracicaba, com o objetivo de facilitar os testes posteriores. A área escolhida possui aproximadamente 0,6 ha e está localizada nas coordenadas geográficas $22^{\circ} 42^{\prime} 46^{\prime \prime} \mathrm{S}$ e $47^{\circ} 37^{\prime} 45^{\prime \prime} \mathrm{W}$. 
b) Caminhamento no perímetro do local selecionado, objetivando obter um mapa de bordadura da área. Para isso, montou-se o DGPS em um trator o qual percorreu a área armazenando os dados georreferenciados.

c) Adição de valores aleatórios ao mapa de bordadura obtido, simulando uma análise de $\mathrm{pH}$ do solo, o que permitiu a confecção de um mapa representando a variabilidade espacial do $\mathrm{pH}$ do solo.

d) Confecção do mapa de recomendação da área, ou seja, o mapa de prescrição de calcário. Para isso, utilizou-se como base o mapa de superfície e os valores de dosagens de calcário a serem aplicados (2000 kg.ha ${ }^{-1}, 3000$ kg.ha ${ }^{-1}$ e 5000 kg.ha ${ }^{-1}$ ).

Estes valores foram escolhidos, uma vez que, a grande maioria das culturas cultivadas no Brasil necessitam dosagens de calcário que variam na faixa de $1500 \mathrm{~kg} \cdot \mathrm{ha}^{-1}$ a $3000 \mathrm{~kg} \cdot \mathrm{ha}^{-1}$. A dosagem de 5000 $\mathrm{kg} \cdot \mathrm{ha}^{-1}$ que excede esta faixa, foi escolhida para se adequar as necessidades da cultura da cana-de-açúcar, que é de grande expressão em área no Brasil (Vitti $\left.{ }^{2}\right)$.

e) Exportação dos mapas de recomendação. Nesse processo de exportação o programa SSTool permite gerar diversas extensões de arquivos. Dentre elas, escolheu-se a ARX devido a clareza de sua estrutura.

Os mesmos procedimentos acima listados foram utilizados para a obtenção dos mapas de prescrição para o ensaio de tempo de resposta. Porém, ao invés de se utilizar a área toda, foi selecionada uma gleba de $60 \times 10 \mathrm{~m}$. Esta foi dividida em três sub-áreas, com comprimentos respectivos de 10, 25 e 25 m. Mapeada esta seção com suas respectivas divisões pôde-se gerar três mapas simulados de prescrição de calcário. No primeiro mapa, os 10 primeiros metros foram representados por uma dosagem de $2000 \mathrm{~kg}^{-h^{-1}}$, os 25 metros seguintes indicavam uma dosagem de $3000 \mathrm{~kg} \cdot \mathrm{ha}^{-1} \mathrm{e}$ os outros 25 metros finais

${ }^{2}$ VITTI, G.C. (ESALQ/USP). Comunicação pessoal, 2000. 
uma dosagem de $2000 \mathrm{~kg} \cdot \mathrm{ha}^{-1}$ novamente. No segundo mapa, as dosagens foram respectivamente de $2000 \mathrm{~kg} \mathrm{ha}^{-1}$ para os 10 primeiros metros, 5000 $\mathrm{kg} \cdot \mathrm{ha}^{-1}$ para os 25 metros seguintes e $2000 \mathrm{~kg} \cdot \mathrm{ha}^{-1}$ novamente, para os 25 metros finais. O ultimo mapa, indicava as dosagens de $3000 \mathrm{~kg} \cdot \mathrm{ha}^{-1}$ para os 10 primeiros metros, $5000 \mathrm{~kg} \cdot \mathrm{ha}^{-1}$ paras os 25 metros seguintes e $3000 \mathrm{~kg} \cdot \mathrm{ha}^{-1}$ para os 25 metros finais.

Todos os mapas estão em coordenadas UTM (Universal Transverse Mercator) a fim de facilitar os cálculos realizados pelo programa de controle do sistema desenvolvido.

\subsubsection{Desenvolvimento do programa de controle do sistema}

O programa desenvolvido tem inicio solicitando ao usuário que transfira as informações contidas no arquivo referente ao mapa de prescrição de calcário com extensão ARX para o computador portátil. Estes dados são convertidos em um arquivo com extensão TXT onde cada linha refere-se à coordenada com sua respectiva dosagem de calcário recomendada. Após esta conversão, o programa solicita ao usuário se deseja ou não iniciar a aplicação localizada a taxas variáveis.

Ao iniciar a aplicação o primeiro passo do programa é realizar através da serial RS-232 do microcomputador uma leitura dos dados provenientes do DGPS, para localização da posição da máquina.

O segundo passo, é selecionar estes dados retirando apenas as coordenadas geográficas (latitude e longitude).

O passo seguinte é transformar essas coordenadas geográficas em coordenadas UTM e armazenar esses valores em suas respectivas variáveis.

No quarto passo, o programa calcula a distancia entre a posição em que a máquina se situa, com os pontos do mapa de prescrição através da Equação1. Para a menor distância encontrada é retirado o valor de dosagem de calcário a ser aplicado e armazenado em uma variável "D". 


$$
d_{i f}=\sqrt{\left(X_{i}-X_{j}\right)^{2}+\left(Y_{i}-Y_{j}\right)^{2}}
$$

sendo:

$$
\begin{aligned}
& X i=\text { longitude calculada pelo DGPS } \\
& X j=\text { longitude indicada pelo mapa de prescrição } \\
& Y i=\text { latitude calculada pelo DGPS } \\
& Y j=\text { latitude indicada pelo mapa de prescrição }
\end{aligned}
$$

$\mathrm{Na}$ etapa seguinte, o programa possibilita a leitura da velocidade do trator e a armazena em uma variável "V".

No sexto passo o programa, baseado na dosagem a ser aplicada, na velocidade da máquina e na largura efetiva da mesma, calcula através da Equação 2 a vazão para o ponto do campo em que a distribuidora está localizada.

$$
D=\frac{Q}{\text { Lef } \times V} \times 10000
$$

sendo:

$$
\begin{aligned}
& D=\text { dosagem }\left(\mathrm{kg} \cdot \mathrm{ha}^{-1}\right) \\
& Q=\text { vazão }\left(\mathrm{kg} \cdot \mathrm{s}^{-1}\right) \\
& \text { Lef = largura efetiva da distribuidora de calcário }(\mathrm{m}) \\
& V=\text { velocidade de deslocamento da máquina }\left(\mathrm{m} \cdot \mathrm{s}^{-1}\right)
\end{aligned}
$$

De posse desse valor, o programa calcula a abertura desejada no mecanismo dosador para aplicar a vazão determinada anteriormente. Este cálculo é realizado através da equação de calibração obtida no ítem 3.2.1.2.

Em seguida, o programa efetua a leitura da abertura do mecanismo dosador. Se o valor desta abertura, não corresponder ao valor calculado, o 
programa aciona o motor de passo, através do controlador, para que o mecanismo dosador se desloque para essa nova posição. O monitoramento da posição da janela de abertura do mecanismo dosador é obtido através da leitura do transdutor potenciométrico ligado a ela.

A seguir descreve-se o algoritmo do programa:

\section{ALGORITMO DE CONTROLE}

1 - Lê o DGPS.

2 - Transforma coordenadas geográficas em UTM.

3 - Procura no mapa de prescrição a coordenada mais próxima e o valor de dosagem de calcário.

4 - Calcula velocidade da distribuidora de calcário através do radar.

5 - Calcula a posição desejada do mecanismo dosador.

6 - Lê o transdutor potenciométrico (posição atual do mecanismo dosador).

7 - Se o posicionamento estiver correto retorna para o item 1.

8 - Aciona o motor de passo para posição desejada.

9 - Retorna para o item 1.

\section{ALGORITMO DE LEITURA DO DGPS}

A rotina de leitura do DGPS é iniciada através da chegada de dados pela saída serial.

1 - Leitura dos dados da serial e armazenamento em uma seqüência de caracteres.

2 - Retirada dos valores de coordenadas geográficas (latitude e longitude).

3 - Armazenamento em uma variável global.

4 - Fim. 
ALGORITMO DE TRANSFORMAÇÃO DE COORDENADAS GEOGRÁFICAS EM UTM

Este algoritmo foi fornecido pelo Prof. Dr. Eder Cassola Molina e Nelsi Cogo de Sá do Instituto Astronômico e Geofísico da Universidade de São Paulo.

\section{ALGORITMO DE PROCURA NO MAPA DE PRESCRIÇÃO}

1 - Ler o valor de um elemento do bloco de dados.

2 - Calcular e armazenar a distância no arquivo junto com o valor da quantidade de corretivo.

3 - Ler o próximo elemento e calcular a distância.

4 - Se a distância for menor ir para o item 6.

5 - Ir para o item 3.

6 - Armazenar a distância e o valor da quantidade de corretivo no buffer.

7 - Se chegou no final do arquivo ir para o item 9.

8 - Ir para o item 3.

9 - Fim.

\section{ALGORITMO DE LEITURA DO RADAR}

1 - Selecionar o canal do conversor A/D referente ao radar.

2 - Ler o valor digital.

3 - Converter, através de fórmula (obtida no item 3.2.1.1), para um valor de velocidade.

4 - Armazenar em uma variável global.

5 - Fim. 


\section{ALGORITMO DE LEITURA DO TRANSDUTOR POTENCIOMÉTRICO}

1 - Selecionar o conversor A/D para o canal do transdutor potenciométrico.

2 - Ler o valor digital.

3 - Converter, através de uma fórmula, para um valor de posição.

4 - Armazenar em uma variável global.

5 - Fim.

\section{ALGORITMO PARA O CÁLCULO DA POSIÇÃO DESEJADA DO MECANISMO DOSADOR.}

1 - Calcula o valor da vazão utilizando a Equação 2 do item 3.2.3.

2 - Calcula abertura do mecanismo dosador utilizando a equação de calibração do item 3.2.1.2.

\section{ALGORITMO DE ACIONAMENTO DO MOTOR DE PASSO}

1 - Determinar a direção de giro do motor de passo.

2 - Enviar uma seqüência de pulsos para o controlador do motor de passo de acordo com a equação obtida no item 3.2.1.4.

3 - Fim.

\subsubsection{Sistema simulador do mecanismo dosador da distribuidora de calcário}

Para otimizar os testes iniciais do programa de controle do sistema de abertura do mecanismo dosador para aplicação variável de calcário, foi construído um sistema simulador do mecanismo dosador da distribuidora de calcário e nele foram instalados os sensores de posição do mecanismo dosador, os conversores analógico/digital e freqüência/tensão, o radar e o motor de passo.

Este sistema foi montado numa plataforma acoplada ao engate de três pontos de um trator para permitir a total mobilidade do sistema e a realização 
de testes de campo. Após a montagem do sistema, fez-se um ensaio para verificar sua acurácia e obter a equação da reta que relaciona abertura do dosador necessária para aplicar a razão indicada pelo mapa de prescrição (qi) e a abertura do dosador indicada pelo transdutor potenciométrico após o acionamento do motor de passo (qo).

\subsubsection{Sistema de controle automático montado na distribuidora de calcário}

A partir do funcionamento satisfatório do simulador do mecanismo dosador da distribuidora de calcário, pôde-se desenvolver os mecanismos de acoplamento entre o sistema e a máquina. Todos os equipamentos foram instalados e adaptados na distribuidora e no trator.

O sensor potenciométrico foi montado de forma que a parte móvel fosse fixada na porta do mecanismo dosador e a parte não móvel no chassi da máquina. A interface de potência foi acondicionada em uma caixa de ferro, a fim de isolar os componentes eletrônicos do pó e da água e foi fixada por meio de parafusos à estrutura da máquina. Para as baterias foi feito um suporte de ferro acoplado ao chassi da máquina. $\mathrm{O}$ acoplamento entre o motor e o eixo que aciona o mecanismo dosador foi efetuado por meio de corrente e engrenagens. Assim, a maior mudança exigida foi a substituição da manivela (para acionamento manual) do eixo por uma engrenagem de 32 dentes e o acoplamento de uma engrenagem de 16 dentes no eixo do motor de passo. Isto permitiu uma redução de transmissão de 2:1. Esta redução gerou um torque suficientemente grande para acionar o mecanismo dosador. 


\subsubsection{Ensaios para caracterização da distribuidora de calcário e do sistema desenvolvido}

Os ensaios para caracterização da distribuidora, ou seja, caracterização da distribuição transversal e longitudinal de calcário (itens 3.2.6.1 e 3.2.6.2), foram realizados seguindo-se a norma ISO 5690/1 (International Standard Organization, 1982)

\subsubsection{Caracterização da distribuição transversal}

O ensaio de distribuição transversal consistiu em alinhar lado a lado, no campo, de forma transversal, 60 coletores como pode ser visto na Figura 10.

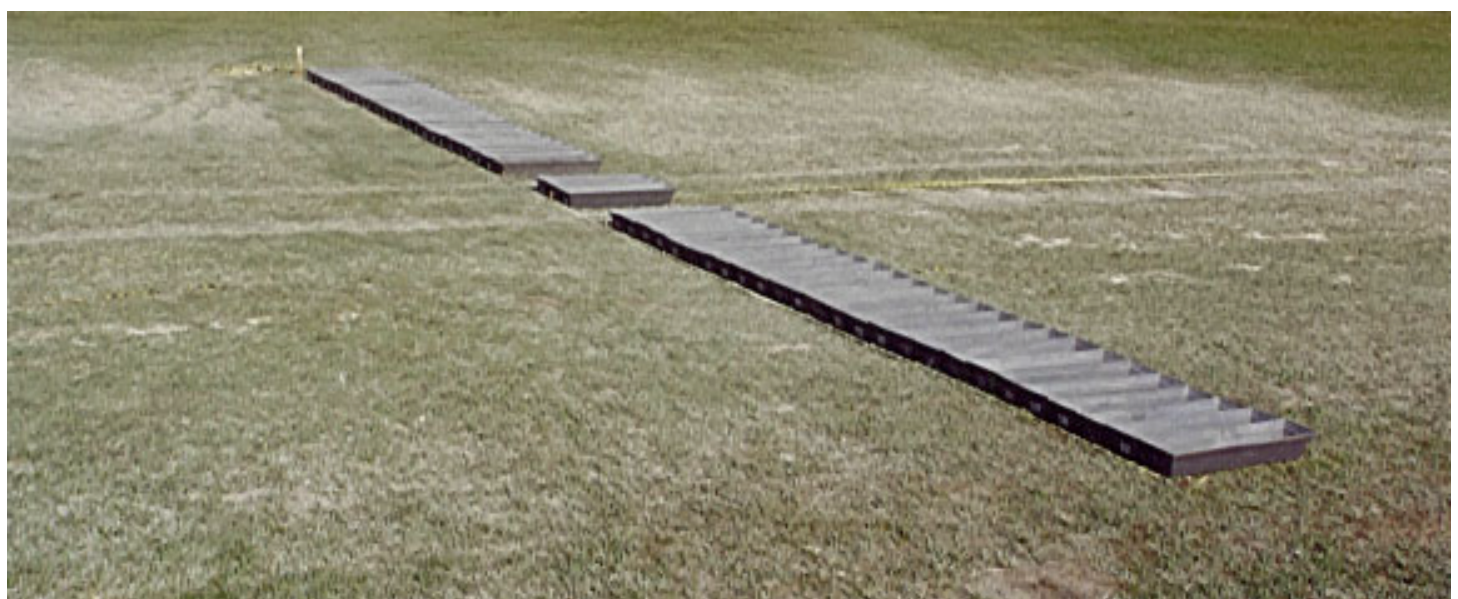

Figura 10 - Disposição dos 60 coletores utilizados no ensaio de distribuição transversal.

Após esta etapa, para cada uma das três repetições realizadas, o conjunto trator/distribuidora fez uma passada na linha dos coletores distribuindo o produto. O material depositado foi recolhido e colocado em sacos de papel para posterior pesagem em balança de precisão.

Realizada a pesagem, obteve-se a deposição total em cada coletor. A partir destes dados foram feitos histogramas, os quais mostram o perfil de 
distribuição transversal do material pela máquina em estudo. Com os mesmos dados, foi possível calcular a largura efetiva (Lef) da distribuidora. O método utilizado para determinar a largura efetiva baseou-se no coeficiente de variação (CV). Para tanto, com o auxilio do programa Adulanço 2.1, realizou-se a simulação de recobrimentos sucessivos com os valores obtidos nos coletores e calculou-se o CV\% para cada situação de recobrimento simulado para a determinação da largura efetiva. Os valores de CV\% para as diferentes larguras efetivas simuladas puderam ser então plotados. O compromisso entre um valor abaixo de $15 \%$ de coeficiente de variação e um valor máximo para largura efetiva é que efetivamente deverá ser utilizado no campo (Parish, 1991; Fulton et al.,1999).

Durante os ensaios monitorou-se a velocidade do vento. Foi tomada esta precaução para evitar que os ensaios fossem realizados com velocidades acima de $2 \mathrm{~m} . \mathrm{s}^{-1}$. Monitorou-se também, a umidade relativa do ar e a temperatura ambiente para evitar que os ensaios fossem realizados com uma umidade relativa acima de $80 \%$. E mediu-se a densidade do calcário. Para determinação da densidade, uma amostra foi retirada do lote do calcário utilizado na avaliação e colocada em uma proveta de $50 \mathrm{~cm}^{3}$. A relação entre a massa obtida e o volume do recipiente forneceu a densidade do produto.

$O$ ensaio foi efetuado utilizando-se uma velocidade de deslocamento do trator de 1,6 m.s. $\left(6 \mathrm{~km} \cdot \mathrm{h}^{-1}\right)$ e dosagens de calcário de $2000 \mathrm{~kg} \cdot \mathrm{ha}^{-1}, 3000$ $\mathrm{kg} \cdot \mathrm{ha}^{-1}$ e $5000 \mathrm{~kg} \cdot \mathrm{ha}^{-1}$.

\subsubsection{Ensaio para determinação do tempo de resposta do sistema}

O ensaio de distribuição longitudinal teve como finalidade a determinação das características de distribuição do equipamento ao longo da linha de deslocamento da máquina, bem como a obtenção do tempo de resposta do equipamento à variação de doses do produto e à quantidade depositada. O ensaio foi realizado com uma largura efetiva (Lef) de $5 \mathrm{~m}$. Os 
coletores foram posicionados a $1,25 \mathrm{~m}$ do centro da máquina ( $25 \%$ da Lef) em duas linhas longitudinais e paralelas na direção do movimento do trator, uma em cada lado da trajetória do conjunto, numa extensão de 60 metros (Figura 11).

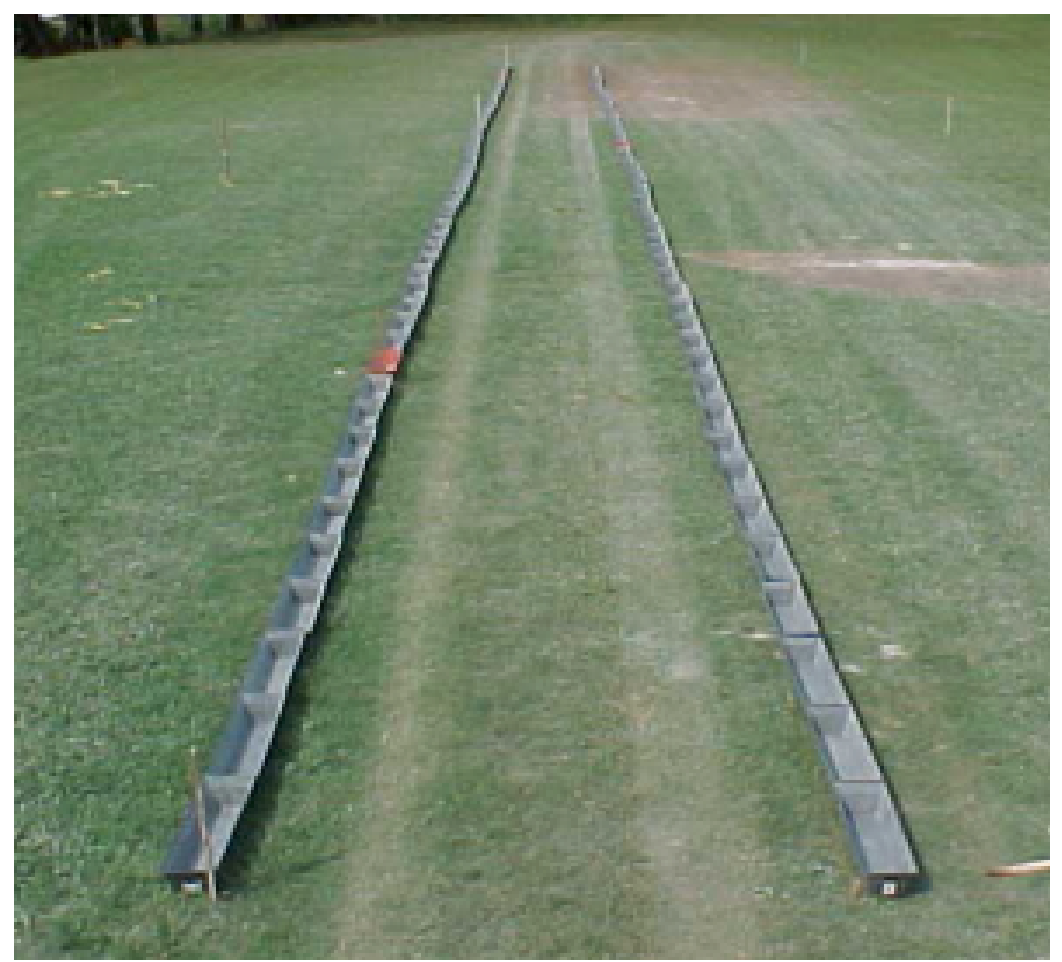

Figura 11 - Disposição dos coletores para o ensaio de tempo de resposta.

Para a obtenção do tempo de resposta à variação de dosagem, o ensaio foi conduzido a uma velocidade de $1,6 \mathrm{~m} \cdot \mathrm{s}^{-1}\left(6 \mathrm{~km} \cdot \mathrm{h}^{-1}\right)$ e três dosagens distintas, distribuídas em três tratamentos: a) dosagem de $2000 \mathrm{~kg} \cdot \mathrm{ha}^{-1}$ nos primeiros 10 metros do percurso, passando a $3000 \mathrm{~kg}^{-\mathrm{ha}^{-1}}$ nos 25 metros seguintes e retornando a $2000 \mathrm{~kg} \cdot \mathrm{ha}^{-1}$ nos 25 metros finais; b) dosagem de $2000 \mathrm{~kg} \cdot \mathrm{ha}^{-1}$ nos primeiros 10 metros do percurso, passando a $5000 \mathrm{~kg} \cdot \mathrm{ha}^{-1}$ nos 25 metros seguintes e retornando a $2000 \mathrm{~kg} \mathrm{ha}^{-1}$ nos 25 metros finais; c) dosagem de $3000 \mathrm{~kg} \cdot \mathrm{ha}^{-1}$ nos primeiros 10 metros do percurso, passando a 
$5000 \mathrm{~kg} \cdot \mathrm{ha}^{-1}$ nos 25 metros seguintes e retornando a $3000 \mathrm{~kg} \cdot \mathrm{ha}^{-1}$ nos 25 metros finais;

A variação da dosagem foi feita pelo sistema controlador desenvolvido com base num mapa de prescrição (item 3.2.2).

Após a passada da distribuidora acoplada ao trator pelos coletores, realizou-se a pesagem e obteve-se a deposição total em cada coletor. Com estes dados foi possível confeccionar os gráficos mostrando a distribuição do calcário ao longo do percurso e determinar o tempo de resposta do sistema de controle para variar de uma dose para outra. Esta determinação consistiu em calcular o espaço percorrido pela distribuidora desde o início da transição de uma dosagem para outra até o momento da estabilização desta nova dosagem. Para identificação destes momentos de estabilização, utilizou-se o parâmetro do coeficiente de variação, o qual descreve a variabilidade dos dados.

Conhecendo-se o valor do espaço percorrido e a velocidade de deslocamento da máquina pôde-se determinar o tempo de resposta que o sistema obteve para realizar uma mudança de dosagem.

\subsubsection{Ensaio de verificação da quantidade de calcário efetivamente aplicada no solo}

O ensaio de verificação da quantidade de calcário efetivamente aplicada no solo consistiu em distribuir nove unidades de lona plástica na área referente ao mapa de prescrição (item 3.2.2). Em cada região, com dosagem diferente no mapa, foram distribuídas três lonas, ou seja, foram realizadas três repetições. Estas lonas foram georreferenciadas para posterior confecção de um mapa com suas localizações.

Em seguida com os discos distribuidores retirados da distribuidora de calcário a máquina acoplada ao trator percorreu a área passando e aplicando o calcário sobre a lona (Figura 12). 


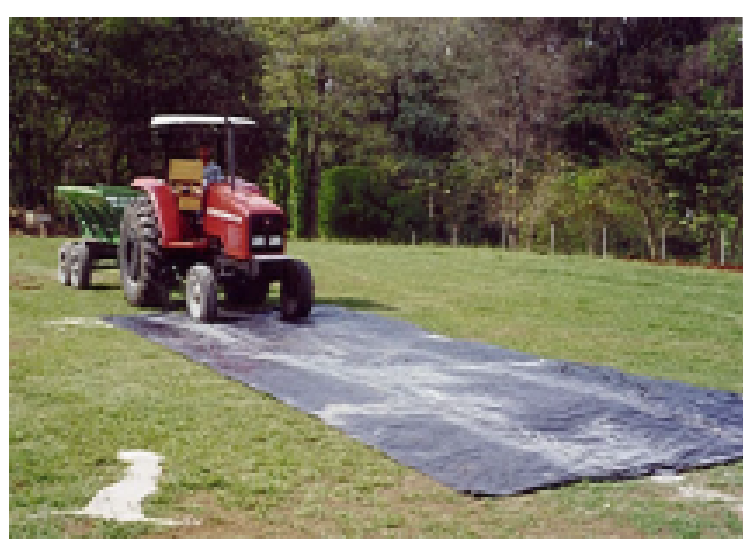

a)

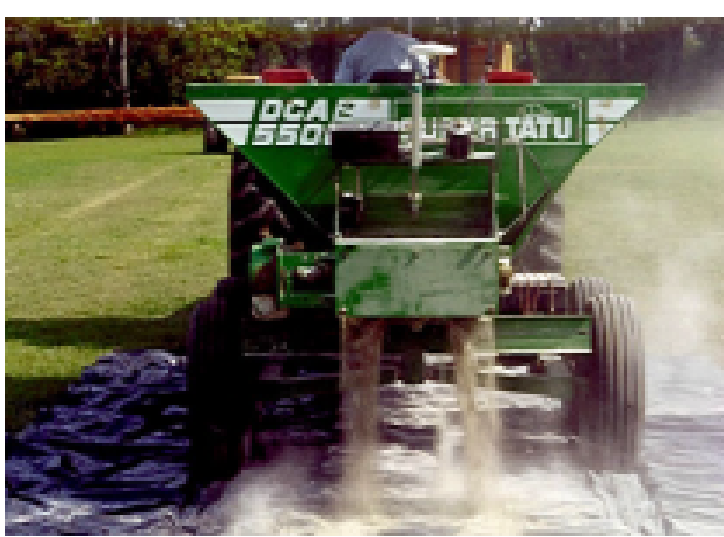

b)

Figura 12 - Ensaio para verificar a quantidade calcário efetivamente aplicada no solo. a) vista frontal do trator entrando na lona; b) vista de trás da distribuidora aplicando o calcário sobre a lona.

Após esta etapa, o calcário depositado em cada lona foi individualmente pesado, com o objetivo de verificar se a quantidade aplicada coincidia com a desejada. Conhecendo a velocidade da máquina $\left(1,6 \mathrm{~m} \cdot \mathrm{s}^{-1}\right.$ ou $\left.6 \mathrm{~km} \cdot \mathrm{h}^{-1}\right)$, a área da lona e a abertura do mecanismo dosador, conseqüentemente a vazão, pôdese calcular qual era a quantidade de calcário que deveria ser aplicada sobre cada lona, ou seja, a quantidade desejada. Comparando-se a quantidade de calcário que deveria ser aplicada em cada lona com a média da quantidade depositada nas três lonas, obteve-se um erro. Na execução deste trabalho um erro abaixo de $3 \%$ foi considerado aceitável. 


\section{RESULTADOS E DISCUSSÃO}

\subsection{Calibrações}

\subsubsection{Calibração do conversor freqüência/tensão}

Os resultados da calibração do conversor freqüência/tensão podem ser vistos na Figura 13.

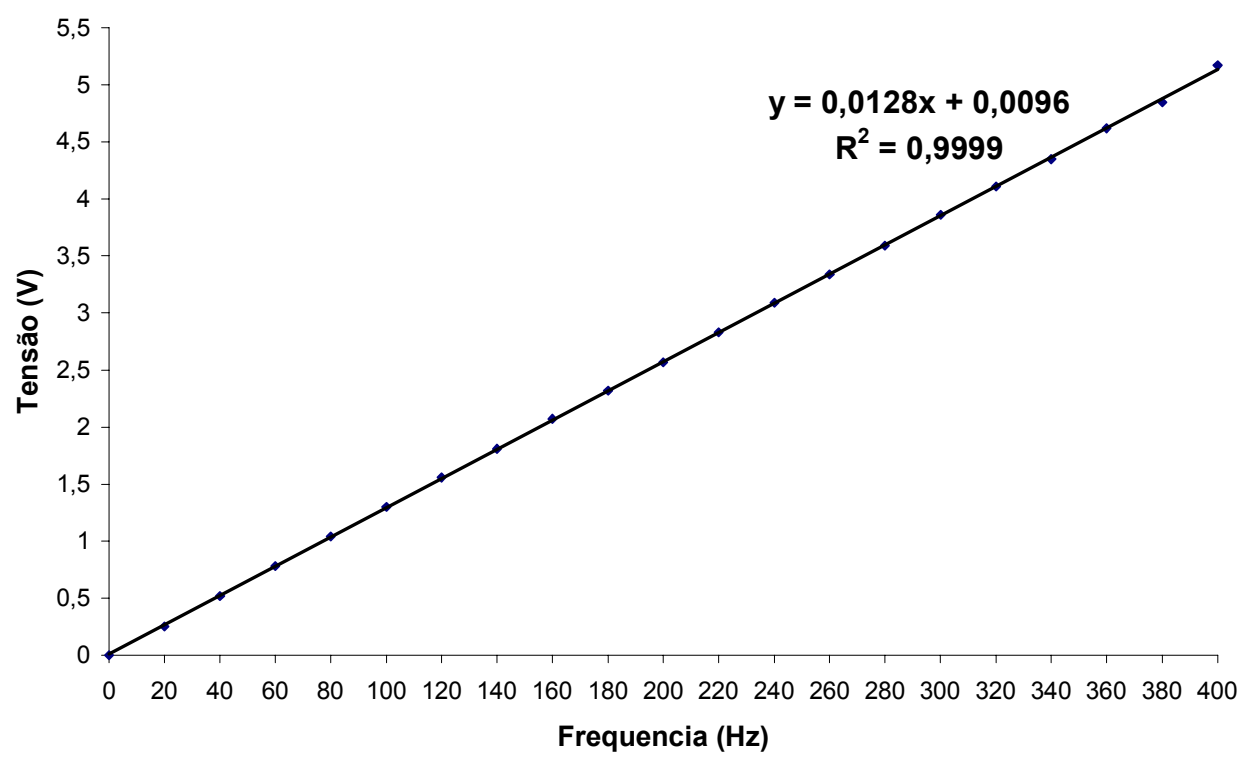

Figura 13 - Dados relacionando freqüência e tensão para aferição da linearidade do conversor freqüência/tensão.

Analisando a Figura 13 pode-se se observar a linearidade do circuito uma vez que o coeficiente de regressão linear foi de 0,99 e que a cada $20 \mathrm{~Hz}$ de freqüência de entrada corresponde a uma amplitude de 0,26 V. 


\subsubsection{Calibração do radar}

A partir dos dados de velocidade, com seus respectivos valores de tensão obtidos neste ensaio, pôde-se determinar uma curva de calibração, com 5 pontos para o radar como mostra a Figura 14.

A equação 3 da curva de calibração gerada foi utilizada no programa de controle do sistema com a finalidade de informar a velocidade de deslocamento da máquina no campo. Analisando-se a figura pode-se verificar a linearidade do radar.

$$
Y=0,7516 X-0,0158
$$

sendo:

$$
\begin{aligned}
& \mathrm{Y}=\text { velocidade }\left(\mathrm{m} \cdot \mathrm{s}^{-1}\right) \\
& \mathrm{X}=\text { tensão }(\mathrm{V})
\end{aligned}
$$

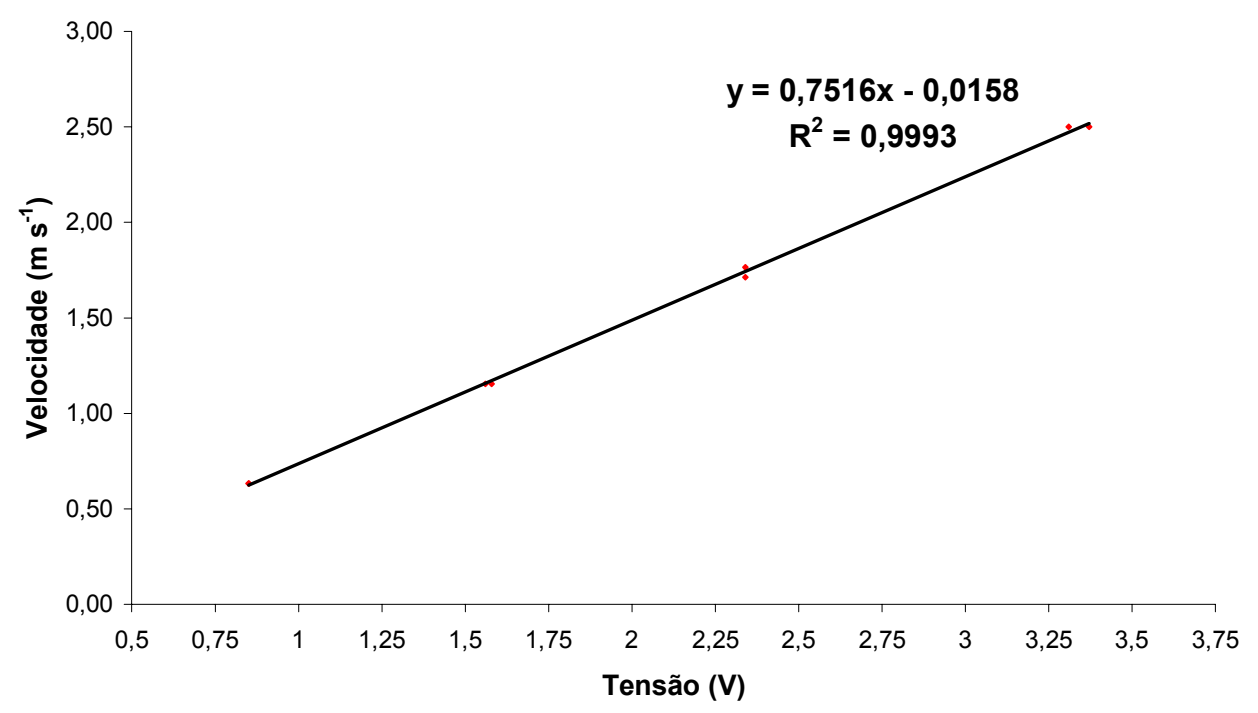

Figura 14 - Curva de calibração do radar. 


\subsubsection{Calibração da vazão da distribuidora de calcário}

A Figura 15 ilustra a curva de calibração de vazão da distribuidora de calcário, obtida através das diversas regulagens de abertura do mecanismo dosador.

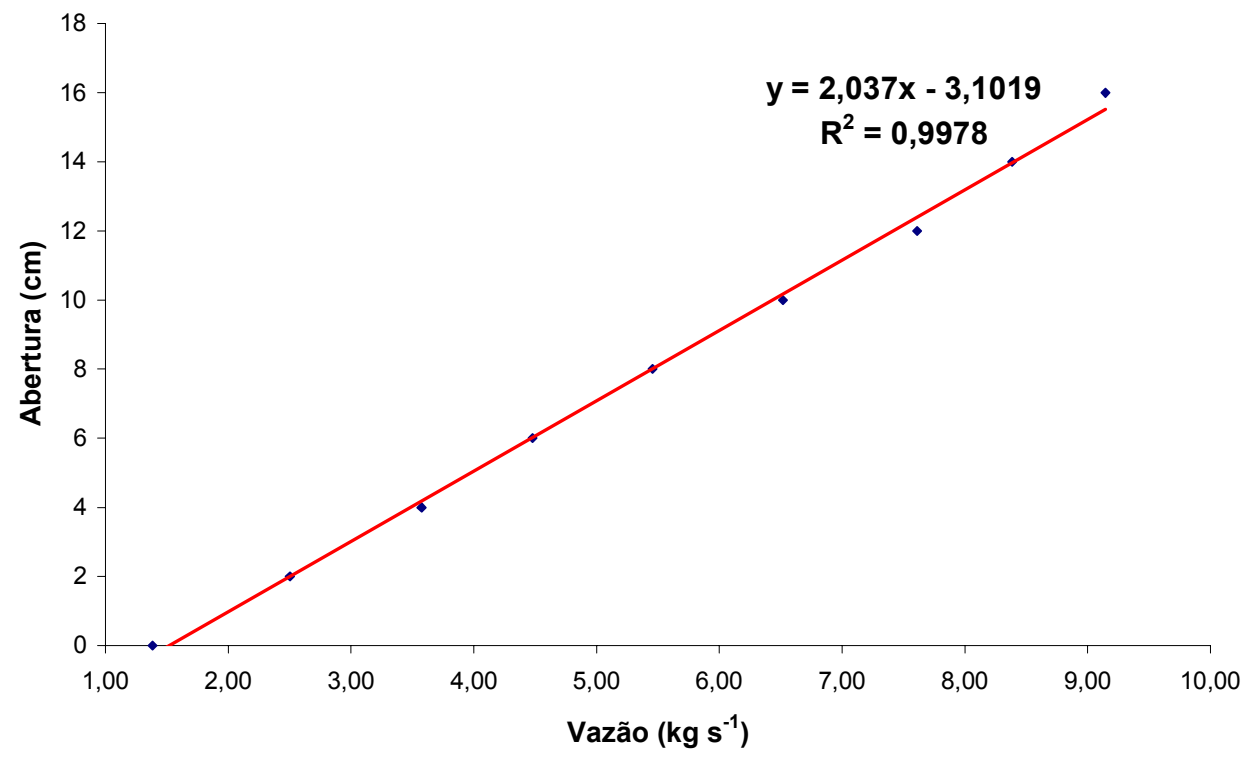

Figura 15 - Curva de calibração da vazão da distribuidora de calcário.

Analisando-se a curva de calibração da distribuidora de calcário, observa-se a regularidade de vazão e uma tendência linear em função do posicionamento do mecanismo dosador. A partir disto, a equação 4 pôde ser implementada no programa de controle.

$$
Y=2,037 X-3,1019
$$

sendo:

$$
\begin{aligned}
& Y=\text { abertura }(\mathrm{cm}) \\
& X=\operatorname{vazão}\left(\mathrm{kg} \cdot \mathrm{s}^{-1}\right)
\end{aligned}
$$


Para a obtenção da curva foram feitas quatro repetições para cada ponto de regulagem e os resultados podem ser vistos na Tabela 1.

Tabela 1. Dados relacionando vazão $\left(\mathrm{kg}^{-1} \mathrm{~s}^{-1}\right)$ com ponto de regulagem para obtenção da curva de calibração da máquina.

\begin{tabular}{|c|c|c|c|c|c|c|}
\hline \multirow[b]{2}{*}{ Aberturas } & \multicolumn{4}{|c|}{ Repetições } & \multirow{2}{*}{ Média } & \multirow{2}{*}{ C.V. } \\
\hline & 1 & 2 & 3 & 4 & & \\
\hline$(\mathrm{cm})$ & -ב-י- & --- & $(\mathrm{kg} \mathrm{s}$ & - & ---- & $\%$ \\
\hline 0 & 1,3 & 1,4 & 1,4 & 1,3 & 1,4 & 3,9 \\
\hline 2 & 2,4 & 2,6 & 2,5 & 2,5 & 2,5 & 4,3 \\
\hline 4 & 3,4 & 3,6 & 3,7 & 3,6 & 3,6 & 4,0 \\
\hline 6 & 4,5 & 4,5 & 4,6 & 4,4 & 4,5 & 1,5 \\
\hline 8 & 5,4 & 5,5 & 5,5 & 5,4 & 5,5 & 1,1 \\
\hline 10 & 6,3 & 6,7 & 6,5 & 6,5 & 6,5 & 2,6 \\
\hline 12 & 7,4 & 7,6 & 7,7 & 7,7 & 7,6 & 1,6 \\
\hline 14 & 8,4 & 8,4 & 8,6 & 8,2 & 8,4 & 2,1 \\
\hline 16 & 9,2 & 8,9 & 9,3 & 9,2 & 9,1 & 2,1 \\
\hline
\end{tabular}

Os dados da Tabela 1 evidenciam a regularidade de vazão, uma vez que o máximo coeficiente de variação não ultrapassou $5 \%$.

\subsubsection{Calibração do sensor potenciométrico}

Após a fixação do sensor potenciométrico no mecanismo dosador da distribuidora de calcário, realizou-se o ensaio descrito no ítem 3.2.1.3.

Com os valores de abertura e tensão pode-se determinar a curva de calibração do sensor potenciométrico (Figura16). Devido a linearidade da curva a equação 5 pôde ser utilizada no programa de controle para possibilitar o cálculo da posição real do mecanismo dosador. 


$$
Y=4,5454 X-1,6242
$$

sendo:

$$
\begin{aligned}
& \mathrm{Y}=\operatorname{abertura}(\mathrm{cm}) \\
& \mathrm{X}=\text { tensão }(\mathrm{V})
\end{aligned}
$$

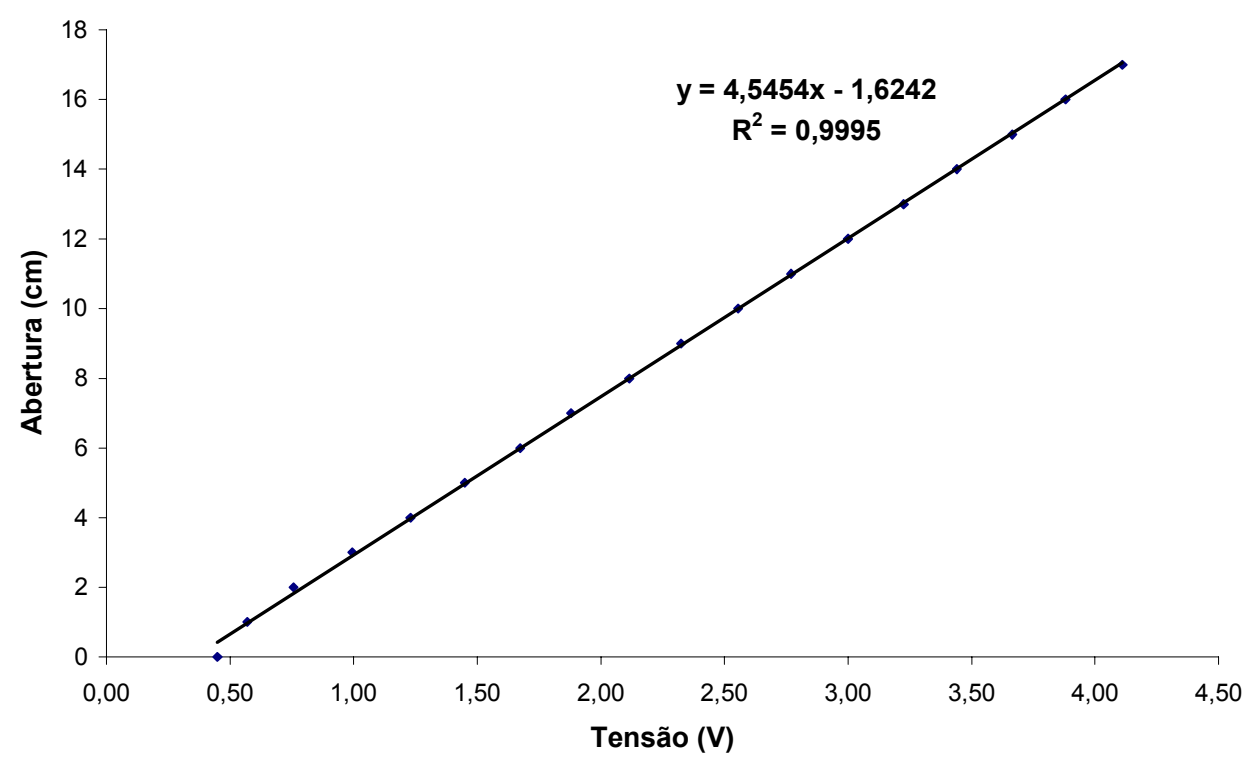

Figura 16 - Curva de calibração do sensor potenciométrico.

\subsubsection{Calibração do mecanismo dosador da distribuidora de calcário}

A Figura 17 mostra a curva de calibração obtida relacionando número de voltas do motor com abertura do mecanismo dosador. A equação 6 da curva também se mostrou linear e foi utilizada pelo programa de controle desenvolvido, para acionar o motor até a posição desejada.

$$
Y=2,494 X-1,776
$$

sendo:

$$
\begin{aligned}
& Y=\text { numero de voltas } \\
& X=\text { abertura }(\mathrm{cm})
\end{aligned}
$$




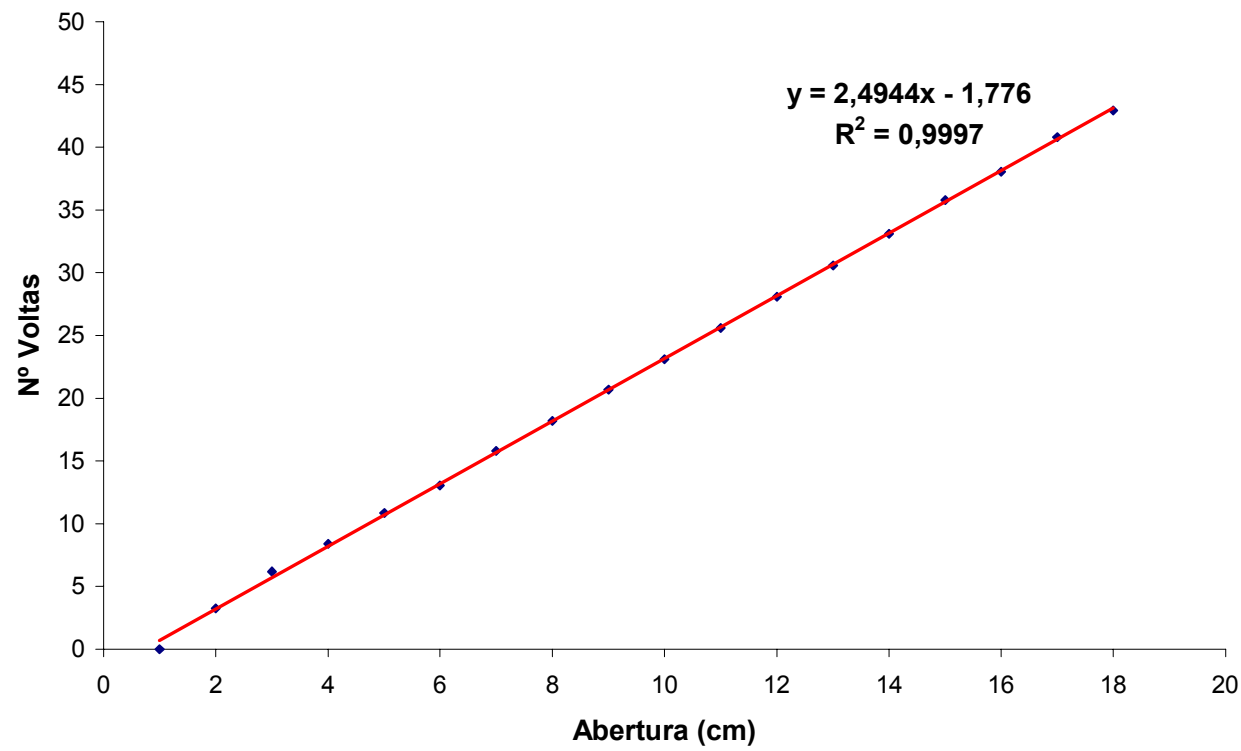

Figura 17 - Curva de calibração do mecanismo dosador da distribuidora de calcário.

\subsection{Confecção do mapa de prescrição de calcário}

Para o ensaio de verificação da quantidade calcário efetivamente aplicada no solo (item 4.6) elaborou-se o mapa de prescrição com uma grade de $5 \times 5 \mathrm{~m}$, o qual pode ser visto na Figura 18. 


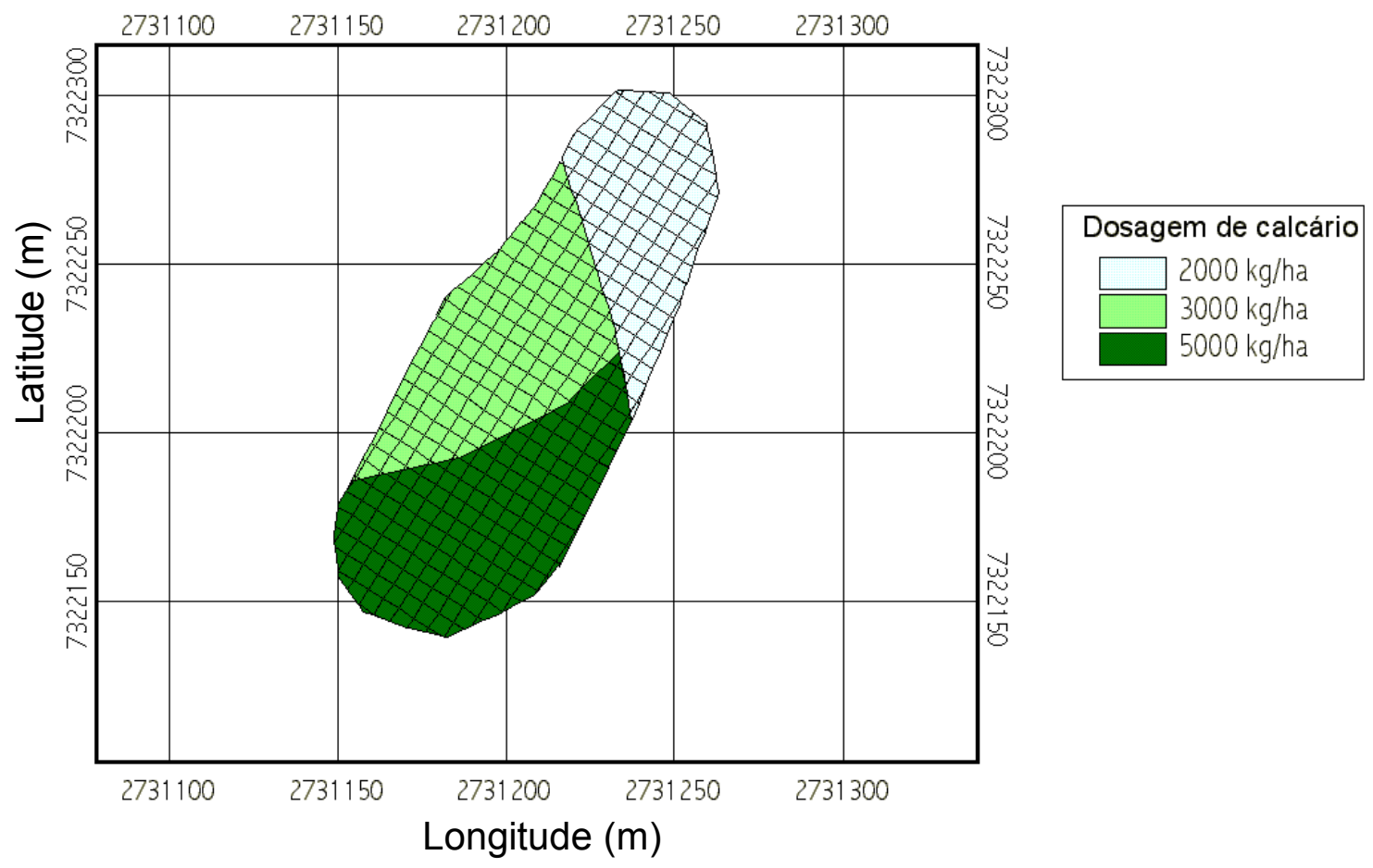

Figura 18 - Mapa de prescrição de calcário simulado para área de estudo.

Conforme a metodologia descrita no ítem 3.2.2 o primeiro mapa refere-se ao ensaio para determinação do tempo de resposta para variações de dosagem de $2000 \mathrm{~kg} \cdot \mathrm{ha}^{-1}$ para $3000 \mathrm{~kg} \cdot \mathrm{ha}^{-1}$, o segundo, para variações de $2000 \mathrm{~kg} \cdot \mathrm{ha}^{-1}$ para $5000 \mathrm{~kg} \cdot \mathrm{ha}^{-1}$, e o terceiro de $3000 \mathrm{~kg} \cdot \mathrm{ha}^{-1}$ para $5000 \mathrm{~kg} \cdot \mathrm{ha}^{-1}$. Os mapas podem ser vistos respectivamente nas Figuras 19, 20 e 21. 


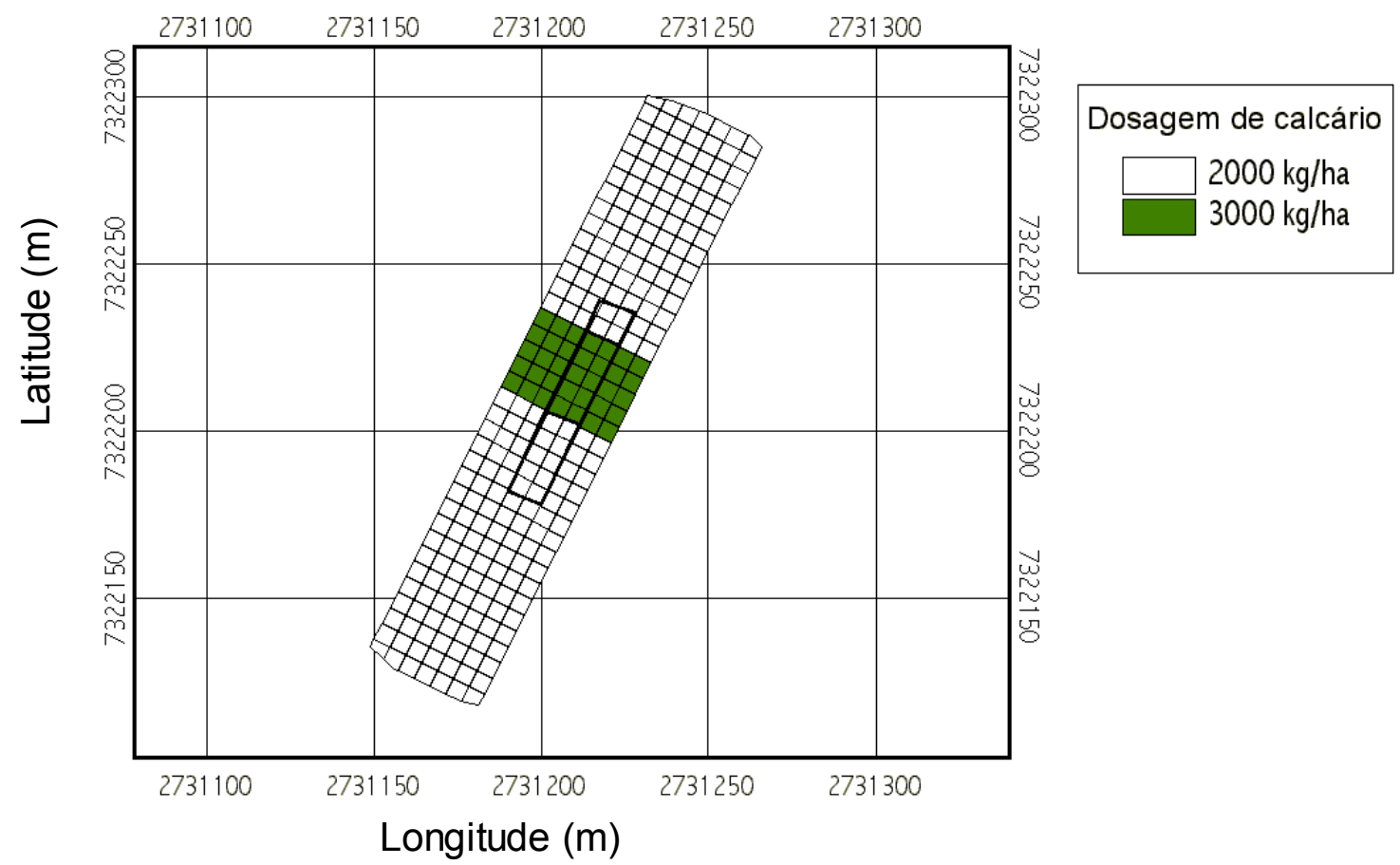

Figura 19 - Mapa de prescrição para dosagens de 2000 e 3000 kg.ha-1 mostrando a gleba utilizada de $60 \mathrm{~m} \times 10 \mathrm{~m}$.

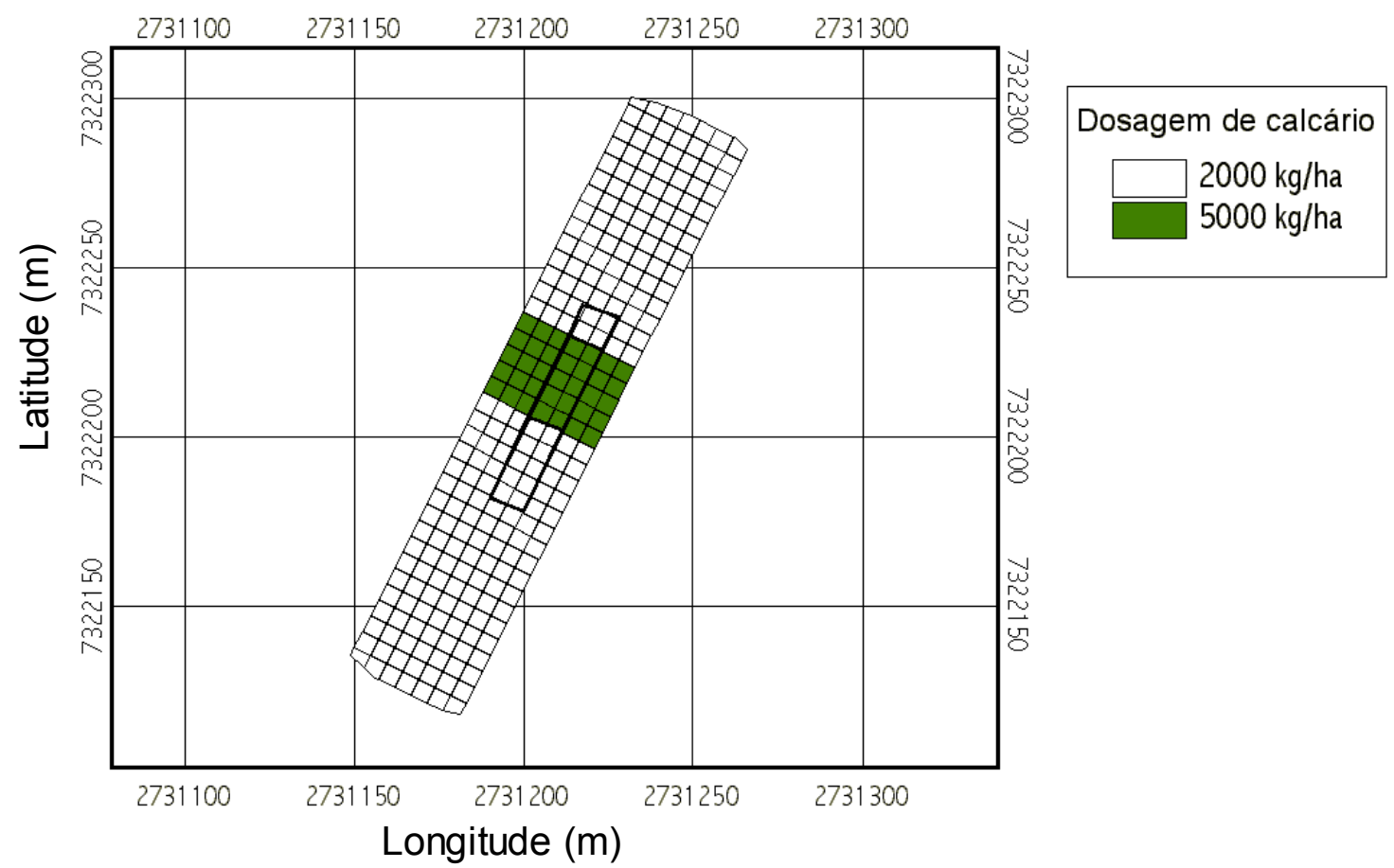

Figura 20 - Mapa de prescrição para dosagens de 2000 e $5000 \mathrm{~kg}^{\mathrm{h}} \mathrm{ha}^{-1}$ mostrando a gleba utilizada de $60 \mathrm{~m} \times 10 \mathrm{~m}$. 


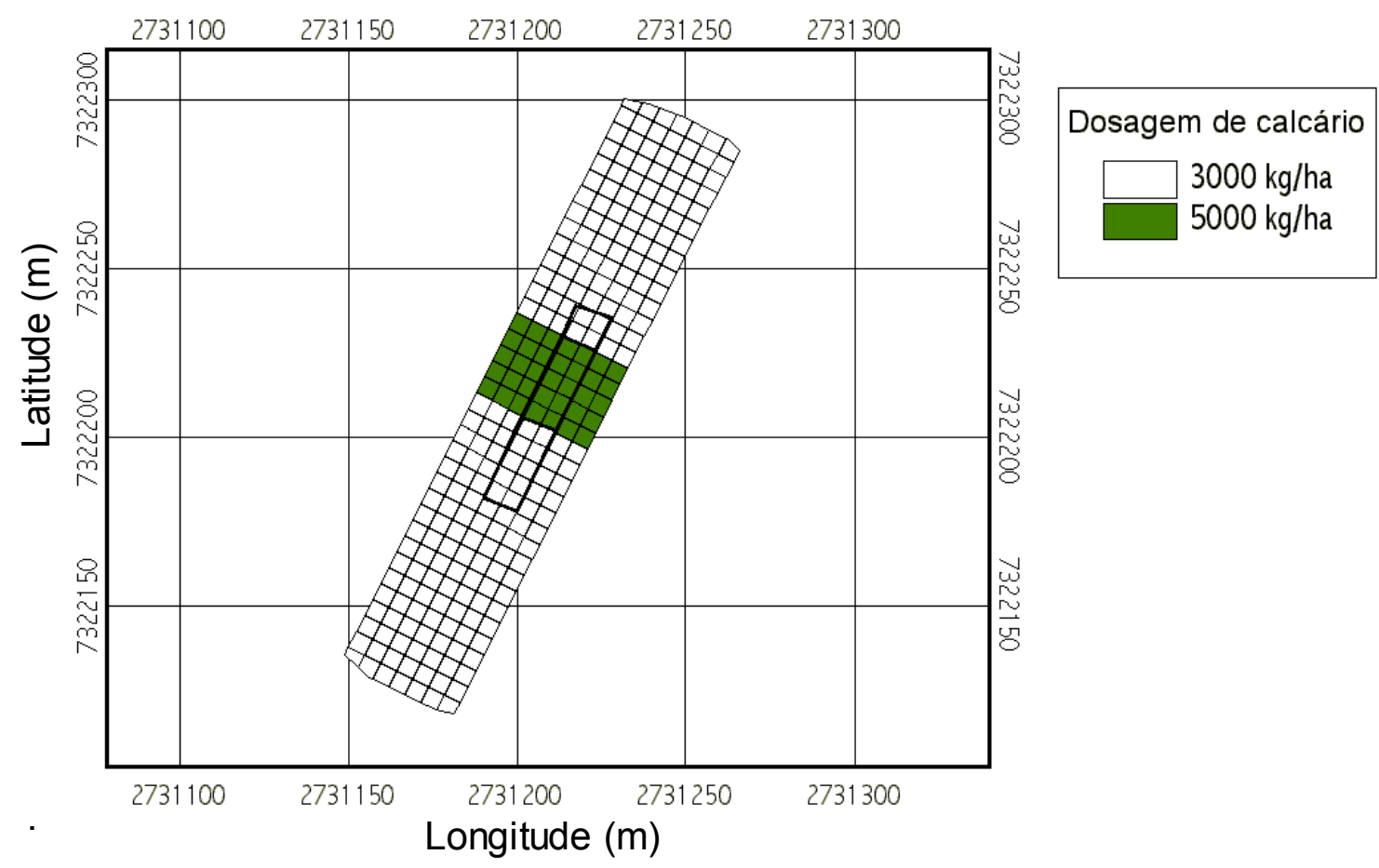

Figura 21 - Mapa de prescrição para dosagens de 3000 e 5000 kg.ha-1 mostrando a gleba utilizada de $60 \mathrm{~m} \times 10 \mathrm{~m}$.

\subsection{Sistema simulador do mecanismo dosador da distribuidora de calcário}

O sistema desenvolvido como simulador do mecanismo dosador da distribuidora de calcário, montado em uma plataforma acoplada ao engate de três pontos do trator pode ser visto na Figura 22. 


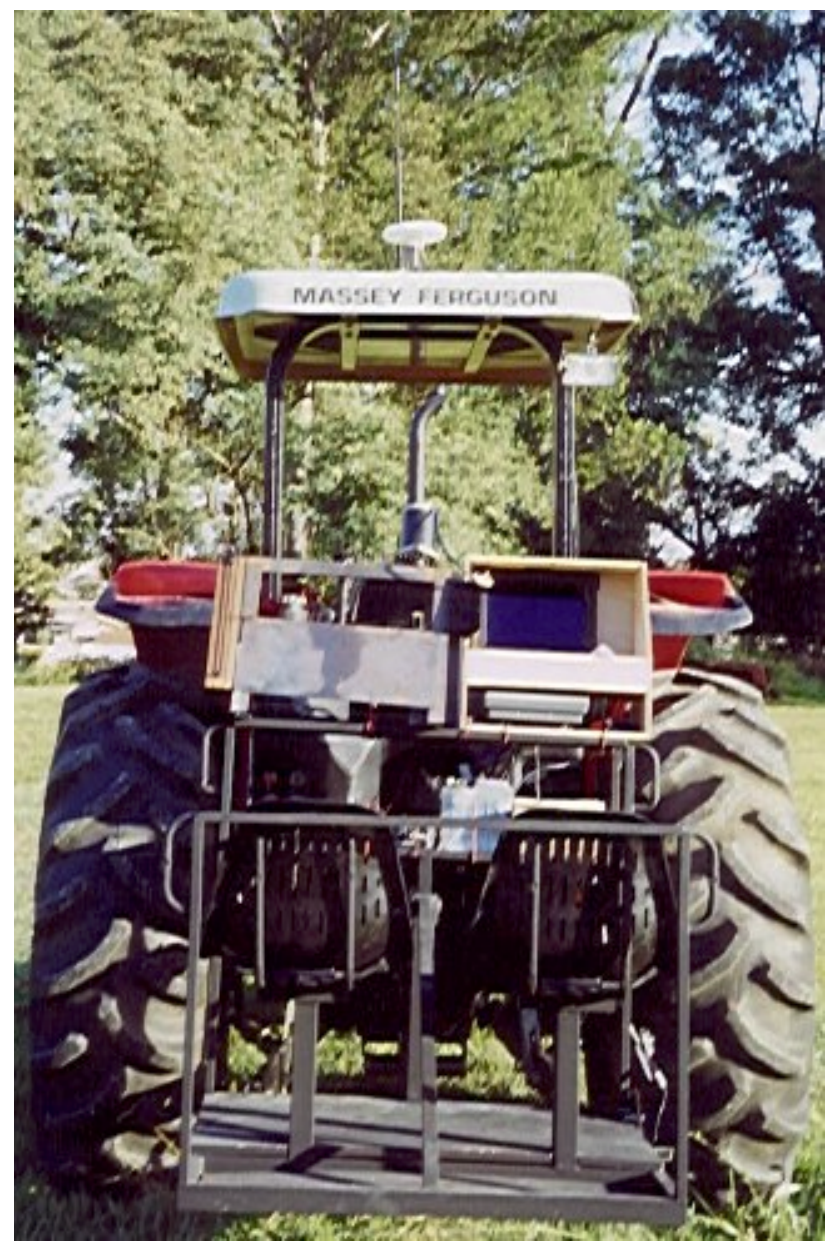

Figura 22 - Sistema simulador do mecanismo dosador montado em um trator.

A equação 7 da curva de calibração do mecanismo dosador calculada pelo método dos quadrados mínimos e a reta obtida podem ser vistas na Figura 23.

$Y=0,9933 X-0,0012$

sendo:

$\mathrm{Y}=$ abertura indicada pelo sensor potenciométrico $(\mathrm{m})$

$\mathrm{X}=$ abertura calculada pelo programa $(\mathrm{m})$

O desvio padrão desses dados foi de $0,19 \mathrm{~cm}$ (sqi) e de $0,20 \mathrm{~cm}$ (sqo).

Assumindo-se uma posição desejada de $3,17 \mathrm{~cm}$, a posição real medida no mecanismo dosador foi de $3,47 \mathrm{~cm}$. A mesma posição calculada através da 
equação da reta foi de $3,64 \mathrm{~cm}$. A diferença entre ambas, denominado de erro sistemático, foi de $-0,17 \mathrm{~cm}$.

Para se determinar o erro total do sistema, somou-se o erro sistemático com o erro ao acaso (3sqi) e obteve-se um valor de $-0,17 \pm 0,57 \mathrm{~cm}$.

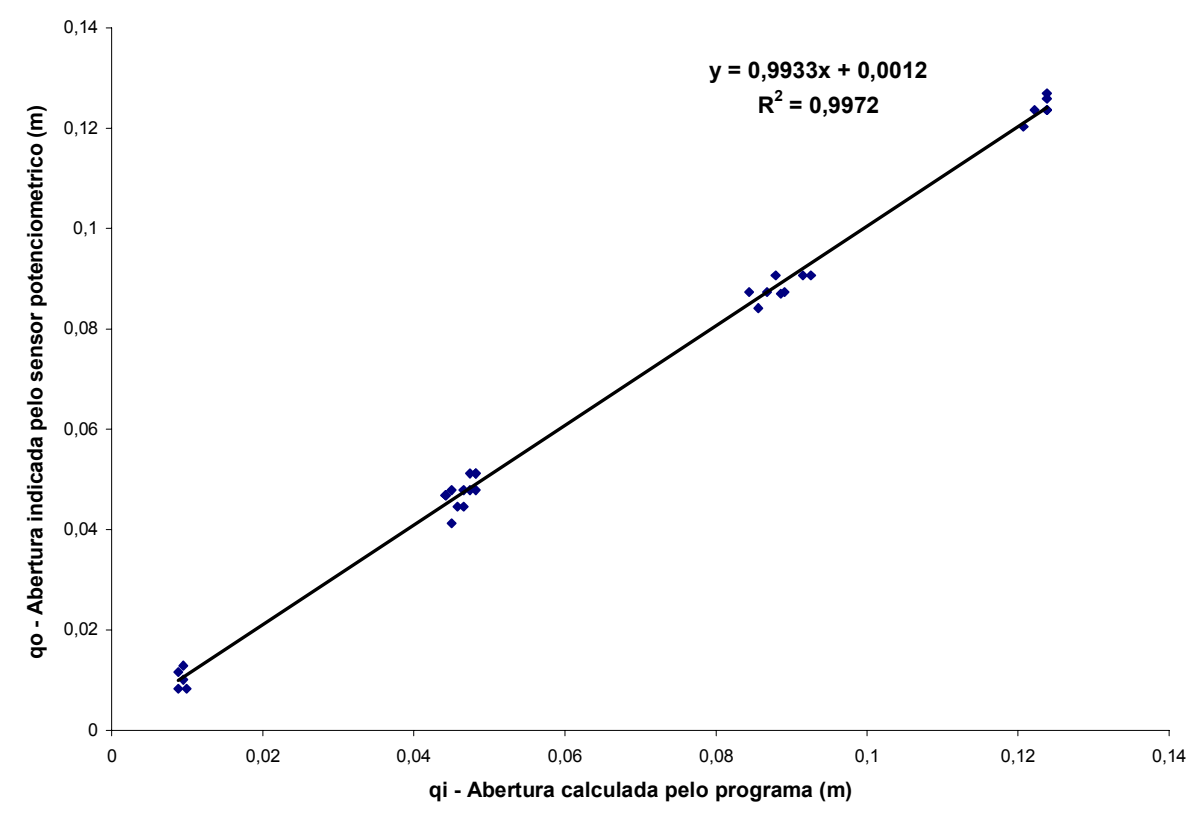

Figura 23 - Curva de calibração do mecanismo dosador

O agrupamento de pontos mostrados na Figura 23 representa os dados coletados pelo sistema a medida que o simulador acoplado ao trator percorria a área referente ao mapa de prescrição. O intervalo entre cada agrupamento ocorreu devido às mudanças de dosagens indicadas pelo mapa de prescrição. Para cada dosagem o programa calculava uma abertura para o mecanismo dosador. O primeiro agrupamento refere-se a dosagem de $1000 \mathrm{~kg} \cdot \mathrm{ha}^{-1}$, o segundo a $2000 \mathrm{~kg} \cdot \mathrm{ha}^{-1}$, o terceiro refere-se a uma dosagem de $3000 \mathrm{~kg} \cdot \mathrm{ha}^{-1} \mathrm{e}$ o quarto a dosagem de $4000 \mathrm{~kg} \cdot \mathrm{ha}^{-1}$. 


\subsection{Ensaios para caracterização da distribuidora de calcário e do sistema desenvolvido}

Para caracterização da distribuidora de calcário e do sistema desenvolvido foram realizados ensaios para avaliar a distribuição transversal, ensaios para obtenção do tempo de resposta e ensaios para verificar se a quantidade de calcário desejada foi a mesma que a realmente aplicada.

\subsubsection{Caracterização da distribuição transversal}

Os ensaios para caracterização da distribuição transversal foram realizados entre os dias 28 e 31 de agosto de 2001. Durante o ensaio a temperatura ambiente permaneceu em torno de $30^{\circ} \mathrm{C}$, a umidade relativa do ar a $45 \%$, velocidade do vento variando de 0,2 a $1,4 \mathrm{~m} \cdot \mathrm{s}^{-1}$ e a densidade do calcário em 1,2 g.cm ${ }^{-3}$.

Na Figura 24 observa-se a média dos diferentes perfis de distribuição transversal a partir dos dados obtidos após a pesagem do calcário coletado para as dosagens de $2000 \mathrm{~kg} \cdot \mathrm{ha}^{-1}, 3000 \mathrm{~kg} \cdot \mathrm{ha}^{-1}$ e $5000 \mathrm{~kg} \cdot \mathrm{ha}^{-1}$. 

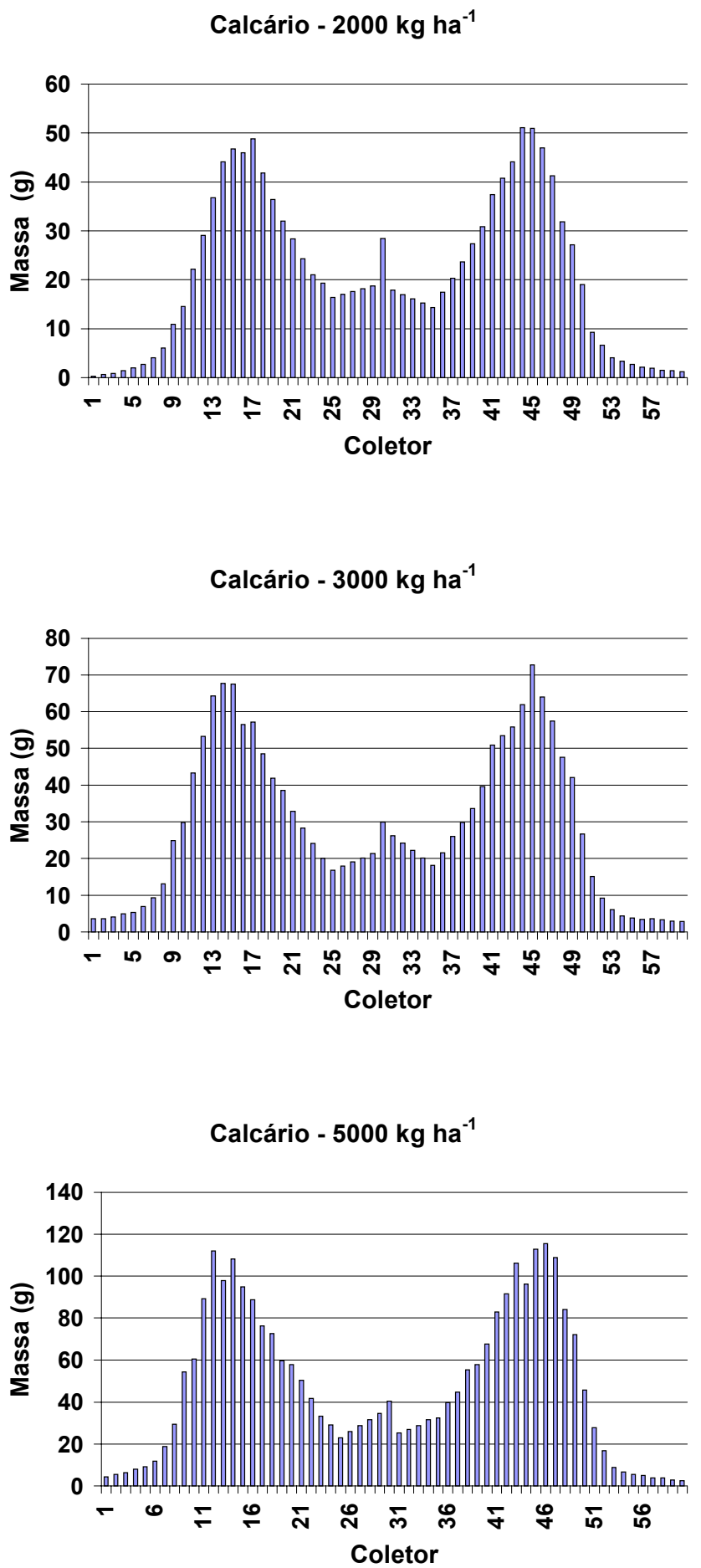

Figura 24 - Perfil médio de distribuição transversal para as dosagens de 2000 , 3000 e 5000 kg.ha-1 de calcário. 
Analisando-se a Figura 24 observa-se que os gráficos apresentam o mesmo perfil de distribuição de calcário, mudando apenas a quantidade de calcário depositada em cada coletor. Portanto, para o calcário, a quantidade de deposição resultou em maior acúmulo de material a medida que a dosagem aumentava. Porém, os perfis obtidos, mesmo apresentando boa simetria, revelam uma queda de aplicação no centro da máquina revelando um formato W a distribuição, fato também observado por Olieslagers, (1997) Ruiz, (1999) e Fulton et al. (1999). O perfil ideal seria um patamar continuo na região da largura efetiva.

Com o auxílio do programa ADULANÇO 2.1, os dados do ensaio de distribuição transversal foram analisados a fim de se obter as relações entre coeficiente de variação e largura efetiva em diferentes percursos: contínuo, direito e esquerdo. Os resultados dessas relações podem ser vistos na Figura 25. 

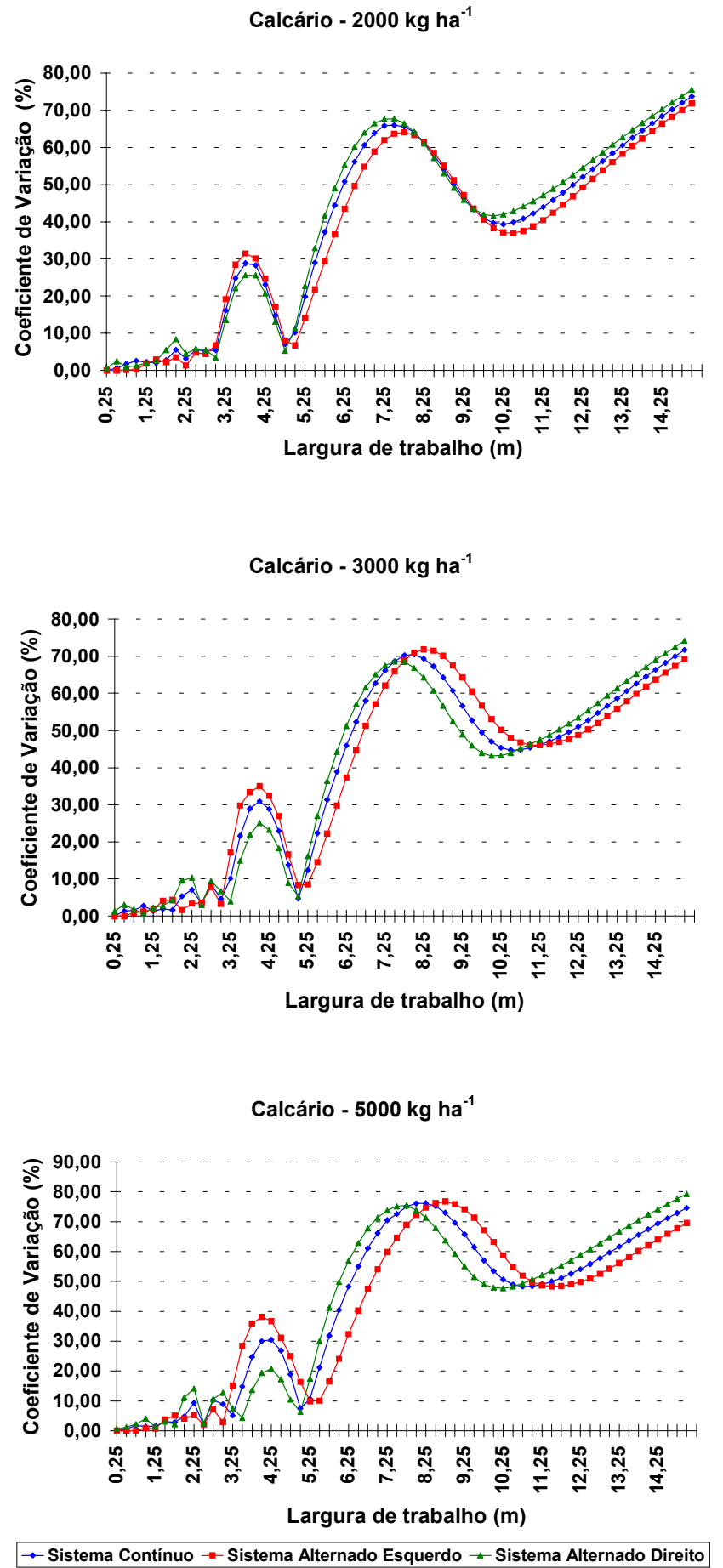

Figura 25 - Resultados simulados do coeficiente de variação em função da largura efetiva de trabalho para os sistemas de percurso continuo, direito e esquerdo para cada dosagem de calcário. 
Analisando-se a Figura 25 e com base em trabalhos realizados por Parish, (1991) e Sogaard \& Kierkegaard, (1994), os quais sugerem que a largura efetiva de trabalho deve ser a maior possível, porém com coeficientes de variação em torno de $15 \%$, pode-se concluir que a largura efetiva de 5 metros foi a que atendeu essas exigências em todos os tipos de percursos. Larguras maiores que 5 metros apresentaram coeficientes muito acima do que o recomendado e larguras menores apresentaram porcentagens baixas de variação, porém não viáveis devido ao baixo rendimento operacional. Uma exceção ocorreu na faixa dos 4,0 a 4,25 metros, onde se pode observar um pico no coeficiente de variação. Este pico ocorreu nesta faixa de largura efetiva devido uma depressão no centro da sobreposição das faixas de aplicação o que determinou uma sobreposição desuniforme e conseqüentemente valores altos de $\mathrm{CV} \%$. O valor de 5 metros de largura efetiva calculado coincide com o valor obtido por Ruiz (1999), o qual também utilizou uma distribuidora de arrasto, modelo DCA 5500 RD. A Tabela 2 refere-se aos coeficientes de variação encontrados nos três tipos de percurso para a largura efetiva de 5 metros nas dosagens de 2000, 3000 e $5000 \mathrm{~kg} \cdot \mathrm{ha}^{-1}$.

Tabela 2. Coeficientes de variação (\%) para largura efetiva de $5 \mathrm{~m}$.

\begin{tabular}{|c|c|c|c|}
\hline \multirow{2}{*}{ Dosagem } & \multicolumn{3}{|c|}{ Tipos de Percurso } \\
\hline & Contínuo & Esquerdo & Direito \\
\hline$\left(\mathrm{kg} \mathrm{ha}^{-1}\right)$ & --- & $---\%$ & \\
\hline 2.000 & 10,21 & 6,76 & 11,39 \\
\hline 3.000 & 4,71 & 8,38 & 5,29 \\
\hline 5.000 & 7,48 & 6,35 & 6,31 \\
\hline
\end{tabular}

Analisando-se a Tabela 2 pode-se observar que o percurso alternado esquerdo foi o que apresentou melhores coeficientes de variação. Portanto, deve ser o sistema de percurso adotado quando se utiliza esta distribuidora, pois irá garantir uma boa regularidade na aplicação transversal de calcário. 


\subsubsection{Ensaio para determinação do tempo de resposta do sistema}

Os ensaios para determinar os tempos de resposta do sistema desenvolvido foram realizados entre os dias 10 e 11 de setembro de 2001. Durante o ensaio a temperatura ambiente permaneceu em torno de $31^{\circ} \mathrm{C}$, a umidade relativa do ar a $55 \%$, velocidade do vento variando de 0,4 a $0,8 \mathrm{~m} . \mathrm{s}^{-1}$, velocidade de deslocamento do trator de 1,6 m.s. $\left(6 \mathrm{~km} \cdot \mathrm{h}^{-1}\right)$ e a densidade do calcário em $1,2 \mathrm{~g} \cdot \mathrm{cm}^{-3}$.

O primeiro tratamento, com a aplicação de dosagens variando de 2000 $\mathrm{kg} \cdot \mathrm{ha}^{-1}$ para $3000 \mathrm{~kg} \cdot \mathrm{ha}^{-1}$, ou seja, uma mudança de taxa de $1000 \mathrm{~kg} \cdot \mathrm{ha}^{-1}$ apresentou a deposição mostrada na Figura 26.

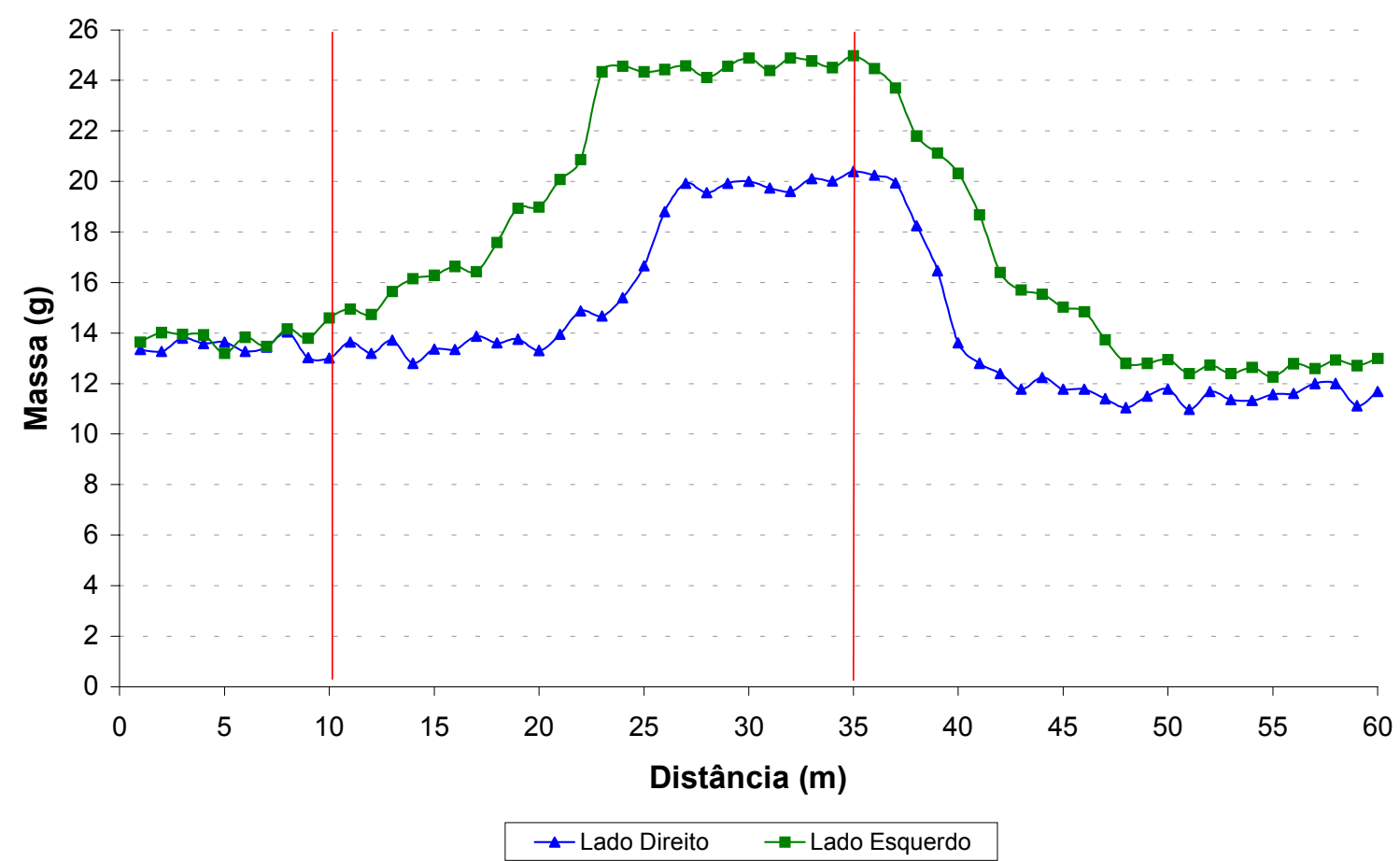

Figura 26 - Faixa de deposição longitudinal para o tratamento com dosagem inicial de $2000 \mathrm{~kg} \cdot \mathrm{ha}^{-1}$, seguida de $3000 \mathrm{~kg} \cdot \mathrm{ha}^{-1}$ e novamente 2000 $\mathrm{kg} \mathrm{ha}^{-1}$; as linhas vermelhas verticais representam os pontos de mudança de dosagem. 
Analisando-se a Figura 26 pode-se constatar que a alteração da dosagem iniciou aos 11 metros, com uma zona de transição de 16 metros, estabilizando-se na nova dosagem aos 27 metros, com um tempo de resposta de 10 segundos quando medida no lado direito. Para o lado esquerdo, o início ocorreu aos 11 metros, se estendendo por 12 metros e finalizando aos 23 metros de percurso, em 7,5 segundos de tempo de resposta. $O$ decréscimo da dosagem medida no lado direito da máquina teve início aos 37 metros, terminando aos 45 metros, estabelecendo zona de transição de 8 metros, percorridos em 5 segundos. Para o lado esquerdo, a dosagem começou a mudança na distância de 36 metros e se estabilizou com 12 metros de transição, aos 48 metros de percurso, com tempo de 7,5 segundos.

A Figura 27 ilustra os resultados obtidos no tratamento com dosagens de 3000,5000 e 3000 kg.ha ${ }^{-1}$.

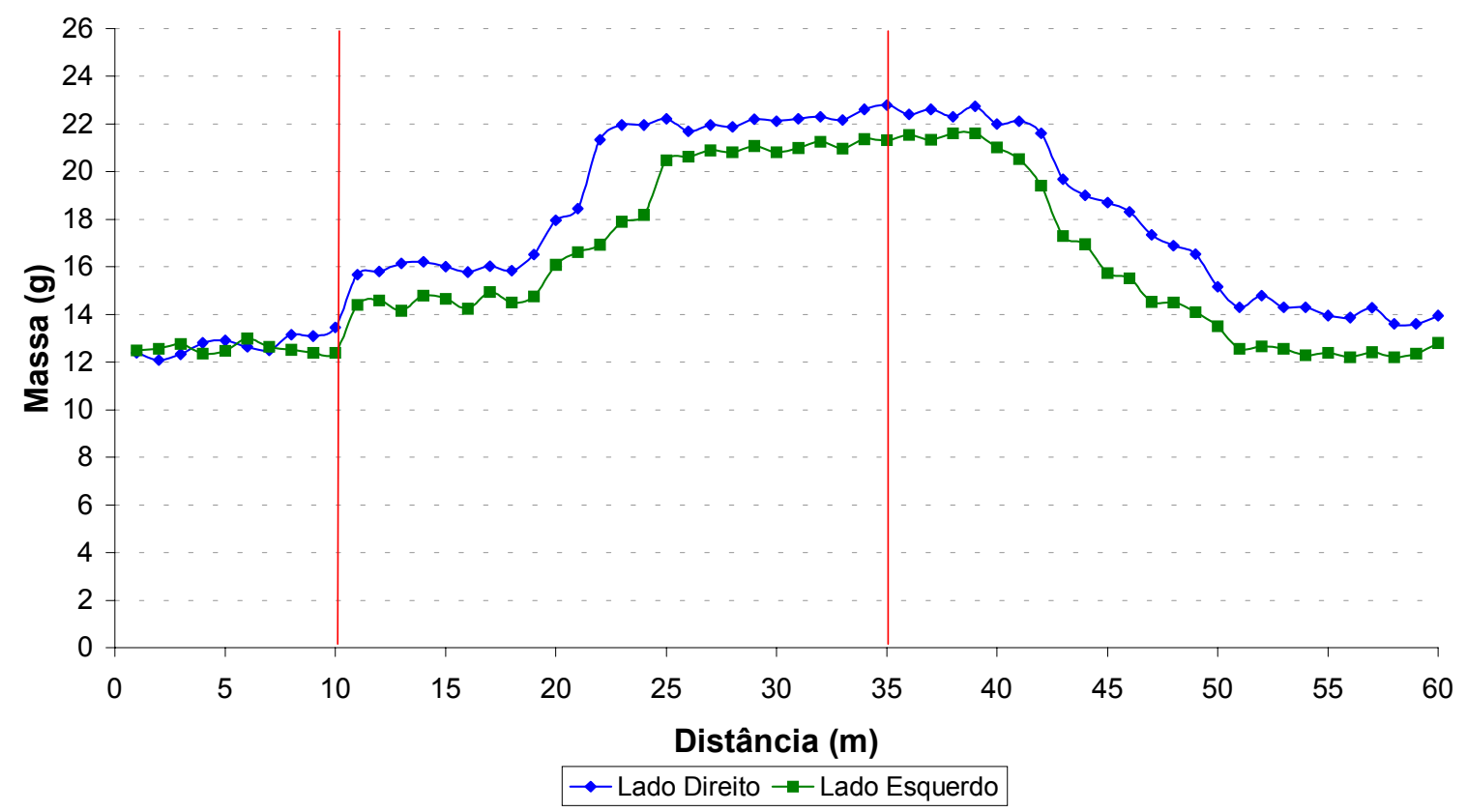

Figura 27 - Faixa de deposição longitudinal para o tratamento com dosagem inicial de $3000 \mathrm{~kg} \cdot \mathrm{ha}^{-1}$, seguida de $5000 \mathrm{~kg} \cdot \mathrm{ha}^{-1}$ e novamente 3000 $\mathrm{kg} \mathrm{ha}^{-1}$; as linhas vermelhas verticais representam os pontos de mudança de dosagem. 
A transição de $3000 \mathrm{~kg} \cdot \mathrm{ha}^{-1}$ para $5000 \mathrm{~kg} \cdot \mathrm{ha}^{-1}$, medida no lado direito da máquina, iniciou aos 11 metros e se estendeu até os 23 metros. Assim, a faixa de transição foi de 12 metros e o tempo de resposta para a mudança de dosagem foi de 7,5 segundos. Para o lado esquerdo, a alteração da dosagem também se iniciou aos 11 metros, mas terminou aos 25 metros, totalizando uma faixa de transição de 14 metros percorridos em 8,7 segundos. No decréscimo da dosagem de $5000 \mathrm{~kg} \cdot \mathrm{ha}^{-1}$ para $3000 \mathrm{~kg} \cdot \mathrm{ha}^{-1}$ medida no lado direito da máquina, o tempo de resposta foi de 5,6 segundos, com faixa de transição de 9 metros, tendo início aos 42 metros e término aos 51 metros. Já para o lado esquerdo da distribuidora, o tempo de resposta foi de 7,5 segundos, iniciando aos 39 metros e finalizando aos 51 metros, perfazendo uma faixa de12 metros de transição.

O terceiro tratamento, com a aplicação de dosagem variando com uma mudança de taxa de $3000 \mathrm{~kg} \cdot \mathrm{ha}^{-1}$, ou seja, de $2000 \mathrm{~kg} \cdot \mathrm{ha}^{-1}$ para $5000 \mathrm{~kg} \cdot \mathrm{ha}^{-1}$ apresentou os resultados mostrados na Figura 28. 


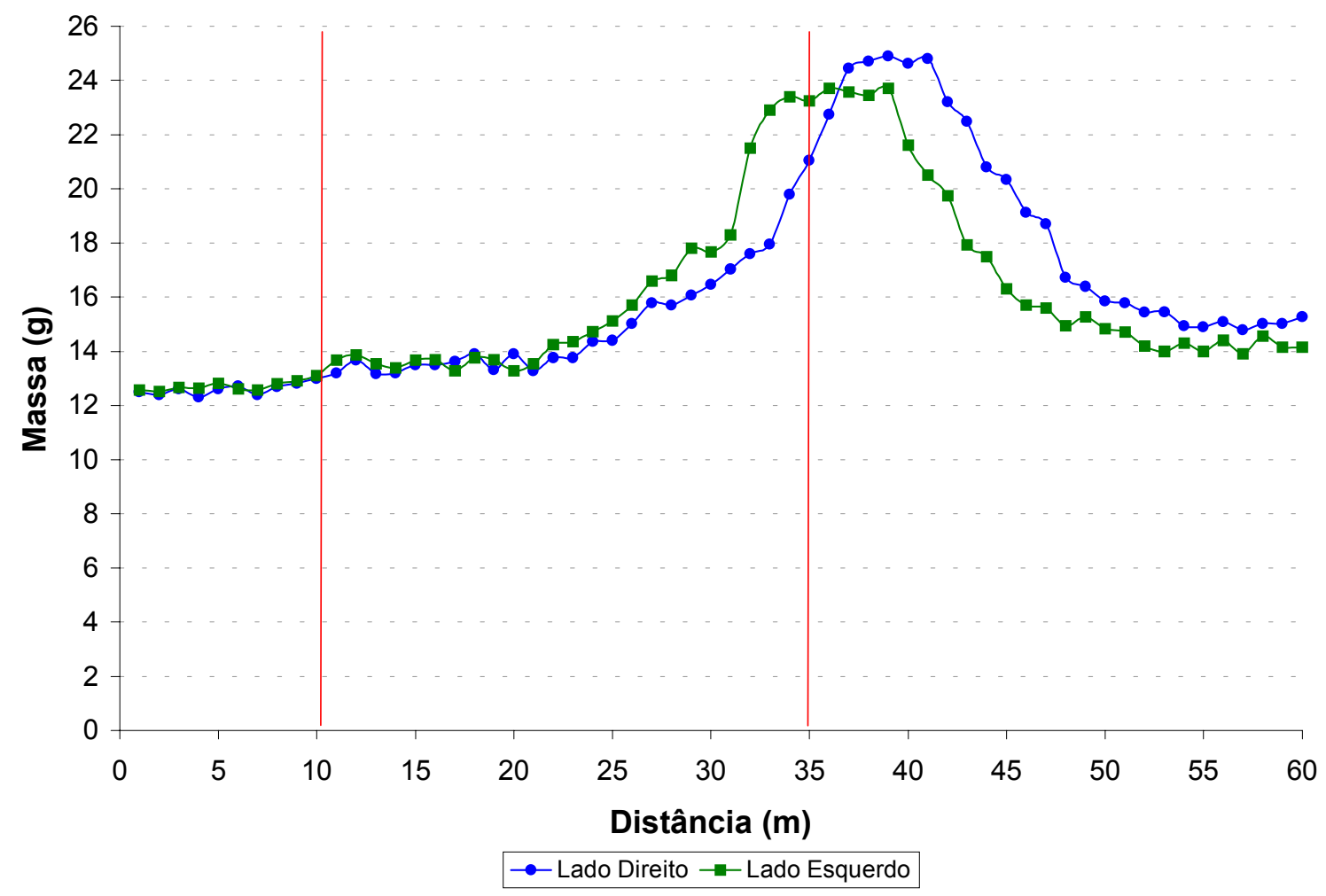

Figura 28 - Faixa de deposição longitudinal para o tratamento com dosagem inicial de $2000 \mathrm{~kg} \mathrm{ha}^{-1}$, seguida de $5000 \mathrm{~kg} \cdot \mathrm{ha}^{-1}$ e novamente 2000

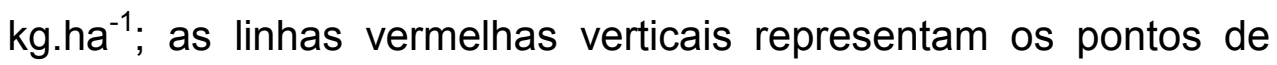
mudança de dosagem.

Assim como os demais tratamentos, a alteração de dosagem teve início aos 11 metros, porém com zona de transição de $27 \mathrm{~m}$, e tempo de resposta de 16,8 segundos quando medida no lado direito (Figura 28). Pelo lado esquerdo, o início também ocorreu aos $11 \mathrm{~m}$, mas se estendeu por 23 metros, finalizando aos 34 metros do percurso, em 14,3 segundos de tempo de resposta. O decréscimo da dosagem medida no lado direito da máquina teve início aos 41 metros, terminando aos $54 \mathrm{~m}$, estabelecendo zona de transição de 13 metros, percorridos em 8,1 segundos. Pelo lado esquerdo, a dosagem começou a mudança na distância, de 39 m e estabilizou-se com 13 m de transição, aos 52 metros de percurso, com tempo de 8,1s. 
Conforme o ítem 3.2.6.2 o momento de estabilização da nova dosagem, ou seja, o momento que finalizava a transição de uma dosagem para outra foi obtida para os três tratamentos utilizando-se o coeficiente de variação. Assim, para este trabalho foi calculado e determinado que toda vez que o coeficiente de variação for menor que 2,8\%, o sistema desenvolvido está aplicando de acordo com a dosagem recomendada. Valores superiores a 2,8\% indicam que o sistema está realizando a transição de uma dosagem para outra, ou seja, não se estabilizou na nova dosagem.

A Tabela 3 resume os resultados obtidos no ensaio de deposição longitudinal para a determinação do tempo de resposta para as diferentes mudanças de dosagem.

Tabela 3. Síntese dos resultados do ensaio para obtenção do tempo de resposta em função das mudanças de dosagem.

\begin{tabular}{ccccc}
\hline \multirow{2}{*}{$\left.\begin{array}{c}\text { Alteração na } \\
\text { Dosagem (kg } \\
\text { ha }\end{array}{ }^{-1}\right)$} & \multicolumn{2}{c}{$\begin{array}{c}\text { Tempo de resposta } \\
(\mathrm{s})\end{array}$} & $\begin{array}{c}\text { Zona de transição } \\
(\mathrm{m})\end{array}$ \\
\cline { 2 - 5 } & Direita & Esquerda & Direita & Esquerda \\
\hline $2000-3000$ & 10 & 7,5 & 16 & 12 \\
$3000-2000$ & 5 & 7,5 & 8 & 12 \\
$2000-5000$ & 16,8 & 14,3 & 27 & 23 \\
$5000-2000$ & 8,1 & 8,1 & 13 & 13 \\
$3000-5000$ & 7,5 & 8,7 & 12 & 14 \\
$5000-3000$ & 5,6 & 7,5 & 9 & 12 \\
\hline
\end{tabular}

Analisando-se os dados da Tabela 3 pode-se constatar que sempre quando o sistema sofre uma alteração de uma dosagem de calcário mais elevada para uma mais baixa o tempo de resposta obtido, para ambos os lados, é menor.

Assim, realizando uma média entre os dois lados os resultados indicam que para mudanças de dosagens de $2000 \mathrm{~kg} \cdot \mathrm{ha}^{-1}$ para $3000 \mathrm{~kg} \cdot \mathrm{ha}^{-1}$, o tempo de resposta foi 2,5 segundos superior em relação às mudanças de dosagens de 
$3000 \mathrm{~kg} \cdot \mathrm{ha}^{-1}$ para $2000 \mathrm{~kg} \cdot \mathrm{ha}^{-1}$. Para mudanças de $3000 \mathrm{~kg} \cdot \mathrm{ha}^{-1}$ para 5000 $\mathrm{kg} \cdot \mathrm{ha}^{-1}$ o tempo de resposta foi 1,5 segundos maior do que para mudanças de $5000 \mathrm{~kg} \cdot \mathrm{ha}^{-1}$ para $3000 \mathrm{~kg} \cdot \mathrm{ha}^{-1}$. O mesmo ocorreu para as trocas de $2000 \mathrm{~kg} \cdot \mathrm{ha}^{-1}$ para $5000 \mathrm{~kg} \cdot \mathrm{ha}^{-1}$, porém, o tempo de resposta foi 7,4 segundos maior em relação às trocas de $5000 \mathrm{~kg} \cdot \mathrm{ha}^{-1}$ para $2000 \mathrm{~kg} \mathrm{ha}^{-1}$, fato ocorrido devido a uma maior mudança de taxa (3000 kg.ha-1 $)$.

O fato do tempo de resposta ser maior para troca de dosagens crescentes em relação a trocas decrescentes, se deve ao efeito de frenagem da massa de calcário sobre a porta do mecanismo dosador, uma vez que este no momento em que inicia uma transição crescente se encontra em maior contato com o calcário em relação ao momento em que se inicia uma transição decrescente de dosagem.

Embora estes tempos de resposta encontrados estejam adequados para o uso na agricultura de precisão, pode-se sugerir que se aumente a rotação do motor de passo a fim de reduzir os tempos encontrados e conseqüentemente, reduzir o espaço não aplicado com a dosagem correta.

\subsection{Ensaio de verificação da quantidade de calcário efetivamente aplicada no solo}

A partir do mapa (Figura 18) confeccionado no item 4.2, pôde-se distribuir na área referente as nove unidades de lona plástica cada uma medindo $10 \times 4$ metros, o que permitiu a confecção do mapa representado pela Figura 29. 


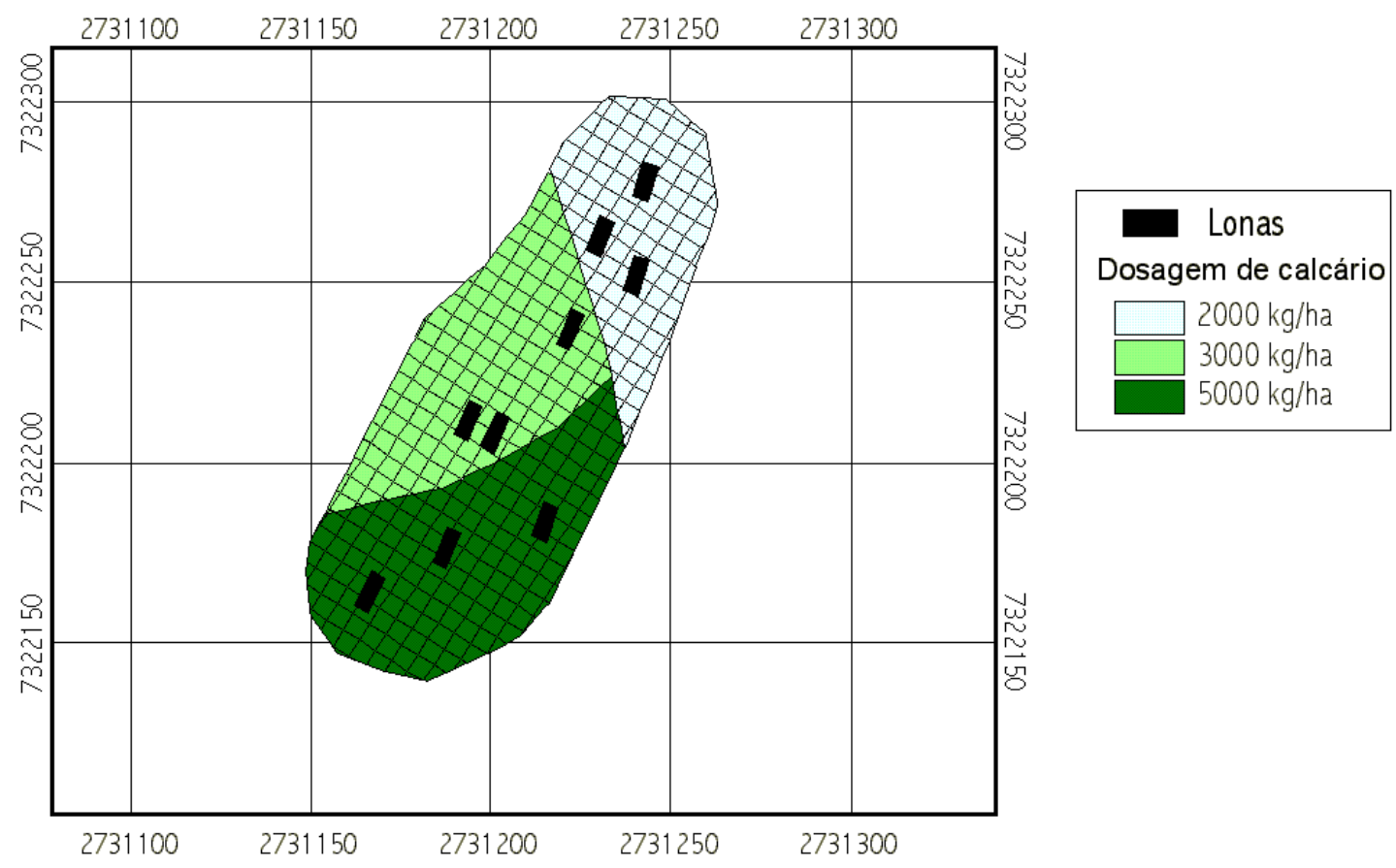

Figura 29 - Distribuição das nove lonas plásticas na área referente ao mapa de prescrição.

A Tabela 4 apresenta os resultados obtidos comparando a quantidade de calcário que deveria ser aplicado sobre a lona, ou seja, a desejada com a realmente aplicada, ou seja, a obtida.

Tabela 4. Dados comparando a quantidade $(\mathrm{kg})$ desejada e a obtida no ensaio de verificação da quantidade calcário efetivamente aplicada no solo para as dosagens de $2000 \mathrm{~kg} \cdot \mathrm{ha}^{-1}, 3000 \mathrm{~kg} \cdot \mathrm{ha}^{-1}$ e $5000 \mathrm{~kg} \cdot \mathrm{ha}^{-1}$.

\begin{tabular}{|c|c|c|c|c|c|c|}
\hline \multirow{3}{*}{ Lonas } & \multicolumn{6}{|c|}{ Dosagem $\left(\mathrm{kg} \mathrm{ha}^{-1}\right)$} \\
\hline & \multicolumn{2}{|c|}{2000} & \multicolumn{2}{|c|}{3000} & \multicolumn{2}{|c|}{5000} \\
\hline & Desejada & Obtida & Desejada & Obtida & Desejada & Obtida \\
\hline 1 & 10,0 & 10,9 & 14,4 & 15,5 & 24,0 & 22,9 \\
\hline 2 & 10,0 & 10,5 & 14,4 & 14,3 & 24,0 & 23,7 \\
\hline 3 & 10,0 & 9,6 & 14,4 & 13,9 & 24,0 & 23,4 \\
\hline Média & 10,0 & 10,3 & 14,4 & 14,6 & 24,0 & 23,3 \\
\hline
\end{tabular}


Analisando a Tabela 4, pôde-se observar que nas lonas localizadas na área representada pela dosagem de $2000 \mathrm{~kg} \cdot \mathrm{ha}^{-1}$ deveria ser aplicado $10 \mathrm{~kg}$ de calcário e a média das três lonas foi de $10,3 \mathrm{~kg}$, originando um erro de $3 \%$. Nas lonas referente a dosagem de $3000 \mathrm{~kg} \cdot \mathrm{ha}^{-1}$ a quantidade desejada era de $14,4 \mathrm{~kg}$ e a média obtida foi de $14,6 \mathrm{~kg}$ equivalente a um erro de $1,4 \%$. Já nas lonas localizadas com dosagem de $5000 \mathrm{~kg} \cdot \mathrm{ha}^{-1}$ o erro foi de $2,9 \%$, uma vez que a quantidade desejada era de $24 \mathrm{~kg}$ e a média calculada foi de $23,3 \mathrm{~kg}$. Esses dados demonstram que os dispositivos de regulagem e distribuição de calcário da máquina funcionaram bem e que a calibração do dispositivo eletroeletrônico foi bem executada. 


\section{CONCLUSÕES}

A partir dos resultados obtidos nos ensaios pode-se concluir que:

1- A montagem e as adaptações efetuadas ocorreram de forma simples e rápida, permitindo facilmente a reprodução deste sistema em qualquer outra distribuidora que possua o mesmo tipo de mecanismo dosador.

2 - A largura efetiva da distribuidora de calcário foi de cinco metros e não sofreu alterações devido às mudanças de dosagens aplicadas de $2000 \mathrm{~kg}^{-\mathrm{ha}^{-1}}, 3000$ $\mathrm{kg} \cdot \mathrm{ha}^{-1}$ e $5000 \mathrm{~kg} \cdot \mathrm{ha}^{-1}$. Para este valor de largura efetiva o coeficiente de variação para os três percursos (contínuo, direito e esquerdo) sempre permaneceu abaixo dos 15\%. O percurso esquerdo apresentou menor coeficiente de variação. Portanto, deve ser o sistema de percurso adotado, pois irá garantir melhor regularidade na aplicação transversal de calcário.

3 - A mudança crescente de taxas tem tempos de resposta maiores que para taxas decrescentes, porém em ambos os casos esses tempos de resposta são adequados para uso na agricultura de precisão.

4 - O erro máximo de distribuição para o sistema desenvolvido está abaixo do limite indicado na bibliografia.

5 - O sistema está funcionando de acordo com o proposto, ou seja, o protótipo desenvolvido está realizando de forma automática e em tempo real a aplicação localizada de calcário a taxas variáveis, tendo como base um mapa de prescrição, com um erro máximo de $3 \%$. 


\section{REFERÊNCIAS BIBLIOGRÁFICAS}

ADAMCHUK, V.I.; MORGAN, M.T.; ESS, D.R. An automated sampling system for measuring pH. Transactions of the ASAE, v.42, n.4, p.885-891, 1999.

BALASTREIRE, L.A. Máquinas agrícolas. São Paulo: Manole, 1987. 308p.

BALASTREIRE, L.A. MAPS-Modeling of Agricultural Systems Spatially. Austin: Texas A\&M University, College Station, 1993. 42p. (Final Report).

BALASTREIRE, L.A. Aplicação Localizada de Insumos - ALI: Um velho conceito novo. In: CONGRESSO BRASILEIRO DE ENGENHARIA AGRÍCOLA, 23., Campinas, 1994. Anais. Campinas: UNICAMP, 1994. p.248.

BALASTREIRE, L.A. Agricultura de precisão. Piracicaba: L.A. BALASTREIRE, 1998. 72p.

BERNOUX, M.M.Y.; ARROUAYS, D.; CERRI, C.C.; BOURENNANE, H. Modeling vertical distribution of carbon in Oxisols of the western Brazilian Amazon. Soil Science, v.163, p.941-951, 1998a.

BERNOUX, M.M.Y.; ARROUAYS, D.; CERRI, C.C.; GRAÇA, P.M. de A.; VOLKOFF, B.; TRICHET, J. Estimation des stocks de carbone des sols du 
Rondônia (Amazonie brésilienne). Études et Gestion des Sols, v.5, n.1, p.31-42, 1998b.

BLACKMER, T.; SCHEPERS, J.S. Using DGPS to improve corn production and water quality. GPS World, p.44-52, 1996.

BONGIOVANNI, R.; DEBOER, J.L. Economics of variable rate lime in Indiana: an overview. In: INTERNATIONAL CONFERENCE ON PRECISION FARMING, 4., Minnesota, 1998. Proceedings. Minnesota: ASA, CSSA, SSSA, 1998. v.2, p.1653-1665.

BORGELT, S.C.; SEARCY, S.W.; STOUT, B.AA.; MULLA, D.J. Spatially variable liming rates: $A$ method for determination. Transactions of the ASAE, v.37, p.1499-1507, 1994.

BOUMA, J. Precision agriculture: A unique tool to unify production and environmental requirements in agriculture. In: INTERNATIONAL CONFERENCE ON PRECISION FARMING, 4., Minnesota, 1998. Proceedings. Minnesota: ASA, CSSA, SSSA, 1998. v.1, p.595-601.

BRAGATO, G.; PRIMAVERA, F. Manuring and soil type influence on spatial variation of soil organic matter properties. Soil Science Society of America Journal, v.62, p.1313-1319, 1998.

BURKE, I.C.; LAUENROTH, W.K.; RIGGLE, R.; BRANNEN, P.; MADIGAN, B.; BEARD, S. Spatial variability of soil properties in the shortgrass steppe: the relative importance of topography, grazing, microsite, and plant species in controlling spatial patterns. Ecosystems, v.2, p.422-438, 1999. 
CASTRIGNANO, A.; GIUGLIARINI, L.; RISALITI, R.; MARTINELLI, N. Study of spatial relationships among soil physico-chemical properties of a field in central Italy using multivariate geostatistics. Geoderma, v.97, n.1/2, p.39-60, 2000.

CHEVALLIER, T.; VOLTZ, M.; BLANCHART, E.; CHOTTE, J.L.; ESCHENBRENNER, V.; MAHIEU, M.; ALBRECHT, A. Spatial and temporal changes in soil $C$ after establishment of a pasture on a long-term cultivated vertisol (Martinique). Geoderma, v.94, n.1, p.43-58, 2000.

CLARK, R.L.; MCGUCKIN, R.L. Variable rate application technology: an overview. In: INTERNATIONAL CONFERENCE ON PRECISION FARMING, 3., Minneapolis, 1996. Proceedings. Madison: ASA, CSSA, SSSA, 1996. p.855-862.

COLVIN, T.S.; JAYNES, D.B.; KARLEN, D.L.; LAIRD, D.A.; AMBUEL, J.R. Six years yield variability within a Central lowa field. In: INTERNATIONAL CONFERENCE ON PRECISION FARMING, 3., Minneapolis, 1996. Proceedings. Madison: ASA, CSSA, SSSA, 1996. p.583.

ESS, D.R.; JOERN, B.C.; HAWKINS, S.E. Development of a precision application system for liguid animal manure. In: INTERNATIONAL CONFERENCE ON PRECISION FARMING, 3., Minneapolis, 1996. Proceedings. Madison: ASA, CSSA, SSSA, 1996. p.863-870.

FULTON, J.P.; SHEARER, S.A.; CHABRA, G.; HIGGINS, S.F. Field evaluation of a spinner disck variable-rate fertilizer applicator. Toronto: ASAE, 1999. (ASAE Paper n. 991101). 
GADANHA JUNIOR, C.D.; MOLIN, J.P.; COELHO, J.L.D. Máquinas e implementos agrícolas do Brasil. São Paulo: NSI-MA, 1991. 468p.

GASTON, L.A.; LOCKE, M.A.; ZABLOTOWICZ, R.M.; REDDY, K.N. Spatial variability of soil properties and weed population in the Mississippi delta. Soil Science Society of America Journal, v.65, p.449-459, 2001.

GOERING, C.E. Recycling a concept. Agricultural Engineering, v.74, p.25, 1993.

GOERING, C.E.; HANS, S. A field information system for SSCM. In: INTERNATIONAL OFF-HIGHWAY \& POWERPLANT CONGRESS \& EXPOSITION, Milwaukee, 1993. Warrendale: SAE, 1993. (SAE Technical Paper Series n. 932422).

GONÇALVES, A.C.A. Variabilidade espacial de propriedades físicas do solo para fins de manejo de irrigação. Piracicaba, 1997. 118p. Tese (Doutorado) - Escola Superior de Agricultura "Luiz de Queiroz", Universidade de São Paulo.

GOOVAERTS, P. Geostatistics in soil science: state-of-the-art and perspectives. Geoderma, v.89, n.1/2, p.1-45, 1999.

INTERNATIONAL STANDARD ORGANIZATION. Metodo de ensayos de distribuidores de abono "a voleo". 5690/1. In: MARQUEZ DELGADO, L. Maquinaria para siembra y abonado métodos de ensayo. Madri: Iranor, 1982. p.95-114.

MAPA, R.B.; KUMARAGAMAGE, D. Variability of soil properties in a tropical alfisol used for shifting cultivation. Soil Technology, v.9, p.187-197, 1996. 
MIALHE, L.G. Características das máquinas distribuidoras de calcário de fabricação nacional. In: SIMPÓSIO SOBRE APLICAÇÃO DE CALCÁRIO NA AGRICULTURA, Campinas, 1986. Campinas: Fundação Cargill, 1986.

MIALHE, L.G. Máquinas agrícolas: ensaio \& certificação. Piracicaba: FEALQ, 1996. $722 p$.

MIELNICZUK, J. Economicidade da calagem. In: SIMPÓSIO ACIDEZ E CALAGEM NO BRASIL, Campinas, 1983. Campinas: SBCS, 1983. p.6477.

MOLIN, J.P.; COELHO, J.L.D.; VASARHELYI, A. Programa computacional para análise de distribuição transversal em aplicadores de fertilizantes e corretivos a lanço. In: CONGRESSO BRASILEIRO DE ENGENHARIA AGRÍCOLA, 21.; SIMPÓSIO DE ENGENHARIA AGRÍCOLA DO CONE SUL, 1., Santa Maria, 1992. Santa Maria: SBEA, 1992. v.4, p.2097-2104.

MONSON, R.J. The Falcon control system for Soilection. St. Joseph: ASAE, 1995. 20p. (Paper 95-1753).

NEUHAUS, P.E.; SEARCY, S.W. Variable planting density and fertilizer rate application system. In: INTERNATIONAL WINTER MEETING '93, Chicago, 1993. Chicago: ASAE, 1993. (Paper n. 93-1554).

OLIESLAGERS, R.H.; BAERDEMAEKER, J. De. Performance of a continuously controlled spinning disc spreader for precision application of fertilizer. In: EUROPEAN CONFERENCE ON PRECISION AGRICULTURE '97, 1., OXFORD, 1997. Proceedings. London: BIOS Scientific Publications, 1997. p.661-668. 
OSTERGAARD, H.S. Agronomic consequences of variable fertilization. In: EUROPEAN CONFERENCE ON PRECISION AGRICULTURE '97, 1., OXFORD, 1997. Proceedings. London: BIOS Scientific Publications, 1997. v.1, p.315-320.

PARISH, R.L. Effect of rough operating surface on rotary spreader distribution pattern. Applied Engineering in Agriculture, v.7, n.1, p.61-63, 1991.

PARISH, R.L. Pattern skewing with a pendulum spreader. St. Joseph: ASAE, 1995. 6p. (ASAE Paper 951303).

PARR, E.A. Industrial control handbook. 2.ed.rev. Oxford: ButterworthHeinemann, 1995. 740p.

PECK, T.R.; MELSTED, S.W. Field sampling for soil testing. In: WALSH, L.M.; BEACON, J.D. Soil testing and plant analysis. Madison: SSSA, 1973. p.67-75.

RAIJ, B. van. Fertilidade do solo e adubação. São Paulo; Piracicaba: Ceres, Potafos, p.343, 1991.

RAWLINS, S. Moving from precision to prescription farming: the next plateau. In: INTERNATIONAL CONFERENCE ON PRECISION FARMING, 3., Minneapolis, 1996. Proceedings. Madison: ASA, CSSA, SSSA, 1996. p.283-294.

RIBEIRO JUNIOR, P.J. Métodos geoestatísticos no estudo da variabilidade espacial de parâmetros do solo. Piracicaba, 1995. 99p. Dissertação (Mestrado) - Escola Superior de Agricultura "Luiz de Queiroz", Universidade de São Paulo. 
RUIZ, E.R.S. Utilização de DGPS como guia para distribuidores a lanço. Piracicaba, 1999. 74p. Dissertação (Mestrado) - Escola Superior de Agricultura "Luiz de Queiroz", Universidade de São Paulo.

SANTA CATARINA. Secretaria de Estado da Agricultura e Abastecimento. Manual de uso, manejo e conservação do solo e da água: Projeto de recuperação, conservação e manejo dos recursos naturais em microbacias hidrográficas. 2.ed.rev. Florianópolis: EPAGRI, 1994. 384p.

SCHUELLER, J.K. A review and integrating analysis of Spatially-Variable Crop Control of crop production. Fertilizer Research, v.33, p.1-34, 1992.

SEARCY, S.W. Computer Integrated Farming with MAPS (Management of Agricultural Production Spatially). Proposal to the Advanced Research Program/Advanced Technology Program. Austin: Texas A\&M University, College Station, 1989. 9p.

SEARCY, S.W. Engineering systems for site-specific management: opportunities and limitations. In: INTERNATIONAL CONFERENCE ON SITE SPECIFIC MANAGEMENT FOR AGRICULTURAL SYSTEMS, 2., Minneapolis, 1994. Proceedings. Madison: ASA, CSSA, SSSA, 1995. p.44.

SKOTNIKOV, A.V.; MCGRATH, D.E. Increasing productivity of equipment for variable rate technology. In: INTERNATIONAL CONFERENCE ON PRECISION FARMING, 4., Minnesota, 1998. Proceedings. Minnesota: ASA, CSSA, SSSA, 1998. v.2, p.1077-1083. 
SLOT, M.H.; GENTHNER, M.H.; DANIELS, W.L.; GROOVER, V.A. Spatial variability in Palustrine wetlands. Soil Science Society of America Journal, v.65, p.527-535, 2001.

SOGAARD, H.T.; KIERKEGAARD, P. Yield reduction resulting from uneven fertilizer distribution. Transaction of the ASAE, v.37, n.6, p.1749-1752, 1994.

STAFFORD, J.V. Essential technology for precision agriculture. In: INTERNATIONAL CONFERENCE ON PRECISION FARMING, 3., Minneapolis, 1996. Proceedings. Madison: ASA, CSSA, SSSA, 1996. p.595-604.

STEVENS, G.; MOYLAN, C.; DUGGER, P.; RICHTER, D. Effect of variable rate lime on cotton yields. In: BELTWIDE COTTON CONFERENCE, Orlando, 1999. Proceedings. Memphis: National Cotton Council, 1999. v.2, p.12851286.

STRAUSS, C.; CUGNASCA, C.E.; SARAIVA, A.M.; PAZ, S.M. The ISO11783 standard and its use in precision agriculture equipment. In: INTERNATIONAL CONFERENCE ON PRECISION FARMING, 4., Minnesota, 1998. Proceedings. Minnesota: ASA, CSSA, SSSA, 1998. v.2, p.1253-1261.

VIEIRA, S.R. Uso da geoestatística em estudos de variabilidade espacial. In: CURSO DE ATUALIZAÇÃO EM CONSERVAÇÃO DO SOLO, Campinas, 1995. Campinas: IAC, 1995. 61p. 
WHITE, J.G.; WELCH, R.M.; NORVELL, W.A. Soil zinc map of the USA using geostatistics and geographic information system. Soil Science Society of America Journal, v.61, p.185-194, 1997.

YANAI, J.; LEE, C.K.; KAHO, T.; IIDA, M.; MATSUI, T.; UMEDA, M.; KOSAKI, T. Geostatistical analysis of soil chemical properties and rice yield in a paddy field and application to the analysis of yield-determining factors. Soil Science and Plant Nutrition, v.47, n.2, p.291-301, 2001.

YANG, J.I.; MOSBY, D.E.; CASTEEL, S.W.; BLANCHAR, R.W. Microscale pH variability for assessing of phosphoric acid treatment in lead-contaminated soil. Soil Science, v.66, n.6, p.374-381, 2001. 